Prepared in cooperation with the city of Wichita, Kansas

\title{
Model Documentation for Relations Between Continuous Real-Time and Discrete Water-Quality Constituents in the North Fork Ninnescah River Upstream from Cheney Reservoir, South-Central Kansas, 1999-2009
}

Open-File Report 2013-1014 



\section{Model Documentation for Relations \\ Between Continuous Real-Time and \\ Discrete Water-Quality Constituents in the \\ North Fork Ninnescah River Upstream from \\ Cheney Reservoir, South-Central Kansas, 1999-2009}

By Mandy L. Stone, Jennifer L. Graham, and Jackline W. Gatotho

Prepared in cooperation with the city of Wichita, Kansas

Open-File Report 2013-1014 


\section{U.S. Department of the Interior \\ KEN SALAZAR, Secretary \\ U.S. Geological Survey \\ Marcia K. McNutt, Director}

U.S. Geological Survey, Reston, Virginia: 2013

For more information on the USGS - the Federal source for science about the Earth, its natural and living resources, natural hazards, and the environment, visit http://www.usgs.gov or call 1-888-ASK-USGS.

For an overview of USGS information products, including maps, imagery, and publications, visit http://www.usgs.gov/pubprod

To order this and other USGS information products, visit http://store.usgs.gov

Any use of trade, firm, or product names is for descriptive purposes only and does not imply endorsement by the U.S. Government.

Although this information product, for the most part, is in the public domain, it also may contain copyrighted materials as noted in the text. Permission to reproduce copyrighted items must be secured from the copyright owner.

Suggested citation:

Stone, M.L., Graham, J.L., and Gatotho, J.W., 2013, Model documentation for relations between continuous real-time and discrete water-quality constituents in the North Fork Ninnescah River upstream from Cheney Reservoir, southcentral Kansas, 1999-2009: U.S. Geological Survey Open-File Report 2013-1014, 101 p. 


\section{Contents}

Abstract
Introduction.
Purpose and Scope
Description of Study Area
Methods
Continuous Water-Quality Monitoring
Quality Assurance and Quality Control
Development of Regression Models to Compute Constituent Concentrations
Results of Regression Analysis for Selected Constituents

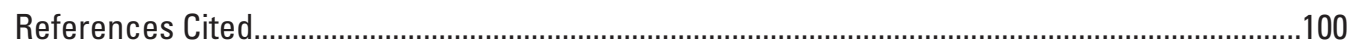

\section{Figures}

1. Map showing location of continuous real-time water-quality monitoring station and land use in the Cheney Reservoir watershed...

2. $\mathrm{S}+{ }^{\circledR}$ output of regression model development using specific conductance (SC) as an explanatory variable for dissolved solids (DS) concentrations for the North Fork Ninnescah River upstream from Cheney Reservoir (site 07144780), south-central Kansas, 1999 through 2009

3. $\mathrm{S}+{ }^{\circledR}$ output graphs from simple linear regression analysis showing $A$, log-transformed specific conductance (SC) versus log-transformed dissolved solids (DS) concentrations; $B$, computed versus actual DS concentrations; $C$, computed log-transformed DS concentrations versus regression residuals; and $D$, standard normal quantiles versus regression residuals for the North Fork Ninnescah River upstream from Cheney Reservoir (site 07144780), south-central Kansas, 1999 through 2009

4. $S+{ }^{\circledR}$ output of regression model development using streamflow (Q) as an explanatory variable for dissolved solids (DS) concentrations for the North Fork Ninnescah River upstream from Cheney Reservoir (site 07144780), south-central Kansas, 1999 through 2009

5. $\mathrm{S}^{\circledR}{ }^{\circledR}$ output graphs from simple linear regression analysis showing $A$, log-transformed streamflow ( 0 ) versus log-transformed dissolved solids (DS) concentrations; $B$, computed versus actual DS concentrations; $C$, computed log-transformed DS concentrations versus regression residuals; and $D$, standard normal quantiles versus regression residuals for the North Fork Ninnescah River upstream from Cheney Reservoir (site 07144780), south-central Kansas, 1999 through 2009 
6. $S+{ }^{\circledR}$ output of regression model development using streamflow $(0)$ and specific conductance (SC) as explanatory variables for calcium (CA) concentrations for the North Fork Ninnescah River upstream from Cheney Reservoir (site 07144780), south-central Kansas, 1999 through 2009.

7. $S+{ }^{\circledR}$ output graphs from simple linear regression analysis using streamflow (0) and specific conductance (SC) as explanatory variables for calcium (CA) showing $A$, computed versus actual $C A$ concentrations; $B$, computed log-transformed $C A$ concentrations versus regression residuals; and $C$, standard normal quantiles versus regression residuals for the North Fork Ninnescah River upstream from Cheney Reservoir (site 07144780), south-central Kansas, 1999 through 2009.

8. $\quad \mathrm{S}^{\circledR}$ output of regression model development using specific conductance (SC) as an explanatory variable for magnesium (MG) concentrations for the North Fork Ninnescah River upstream from Cheney Reservoir (site 07144780), south-central Kansas, 1999 through 2009

9. $\mathrm{S}+{ }^{\circledR}$ output graphs from simple linear regression analysis showing $A$, log-transformed specific conductance (SC) versus log-transformed magnesium (MG) concentrations; $B$, computed versus actual MG concentrations; $C$, computed log-transformed $M G$ concentrations versus regression residuals; and $D$, standard normal quantiles versus regression residuals for the North Fork Ninnescah River upstream from Cheney Reservoir (site 07144780), south-central Kansas, 1999 through 2009 .

10. $S+{ }^{\circledR}$ output of regression model development using specific conductance (SC) as an explanatory variable for sodium (NA) concentrations for the North Fork Ninnescah River upstream from Cheney Reservoir (site 07144780), south-central Kansas, 1999 through 2009

11. $\mathrm{S}+{ }^{\circledR}$ output graphs of simple linear regression analysis showing $A$,

log-transformed specific conductance (SC) versus log-transformed sodium (NA) concentrations; $B$, computed versus actual NA concentrations; $C$, computed log-transformed NA concentrations versus regression residuals; and $D$, standard normal quantiles versus regression residuals for the North Fork Ninnescah River upstream from Cheney Reservoir (site 07144780), south-central Kansas, 1999 through 2009

12. $S+{ }^{\circledR}$ output of regression model development using streamflow $(0)$ as an explanatory variable for sodium (NA) concentrations for the North Fork Ninnescah River upstream from Cheney Reservoir (site 07144780), south-central Kansas, 1999 through 2009

13. $\mathrm{S}+{ }^{\circledR}$ output graphs from simple linear regression analysis showing $A$, log-transformed streamflow ( $Q$ ) versus log-transformed sodium (NA) concentrations; $B$, computed versus actual NA concentrations; $C$, computed log-transformed NA concentrations versus regression residuals; and $D$, standard normal quantiles versus regression residuals for the North Fork Ninnescah River upstream from Cheney Reservoir (site 071447800), south-central Kansas, 1999 through 2009

14. $\quad \mathrm{S}^{\circledR}$ output of regression model development using specific conductance (SC) as an explanatory variable for chloride (CL) concentrations for the North Fork Ninnescah River upstream from Cheney Reservoir (site 07144780), south-central Kansas, 1999 through 2009 
15. $\quad S+{ }^{\circledR}$ output graphs from simple linear regression showing $A$, log-transformed specific conductance (SC) versus log-transformed chloride (CL) concentrations; $B$, computed versus actual $C L$ concentrations; $C$, computed log-transformed $C L$ concentrations versus regression residuals; and $D$, standard normal quantiles versus regression residuals for the North Fork Ninnescah River upstream from Cheney Reservoir (site 07144780), south-central Kansas, 1999 through 2009.

16. $S+{ }^{\oplus}$ output of regression model development using streamflow $(0)$ as the explanatory variable for chloride (CL) concentrations for the North Fork Ninnescah River upstream from Cheney Reservoir (site 07144780), south-central Kansas, 1999 through 2009

17. $\mathrm{S}+{ }^{\circledR}$ output graphs from simple linear regression analysis showing $A$, log-transformed streamflow ( 0 ) versus log-transformed chloride (CL) concentrations; $B$, computed versus actual $C L$ concentrations; $C$, computed log-transformed $\mathrm{CL}$ concentrations versus regression residuals; and $D$, standard normal quantiles versus regression residuals for the North Fork Ninnescah River upstream from Cheney Reservoir (site 07144780), south-central Kansas, 1999 through 2009

18. $\mathrm{S}+{ }^{\circledR}$ output of regression model development using specific conductance (SC) as an explanatory variable for potassium (K) concentrations for the North Fork Ninnescah River upstream from Cheney Reservoir (site 07144780), south-central Kansas, 1999 through 2009

19. $S+{ }^{\circledR}$ output graphs from simple linear regression analysis using specific conductance (SC) and log-transformed SC as explanatory variables for potassium (K) concentrations showing $A$, computed versus actual $\mathrm{K}$ concentrations; $B$, computed log-transformed $K$ concentrations versus regression residuals; and $C$, standard normal quantiles versus regression residuals for the North Fork Ninnescah River upstream from Cheney Reservoir (site 07144780), south-central Kansas, 1999 through 2009

20. $\mathrm{S}+{ }^{\circledR}$ output of regression model development using specific conductance (SC) as an explanatory variable for sulfate (SO4) concentrations for the North Fork Ninnescah River upstream from Cheney Reservoir (site 07144780), south-central Kansas, 1999 through 2009

21. $\mathrm{S}^{\circledR}{ }^{\circledR}$ output graphs from simple linear regression analysis showing $A$, specific conductance (SC) versus sulfate ( $\mathrm{SO} 4$ ) concentrations; $B$, computed versus actual SO4 concentrations; $C$, computed $\mathrm{SO} 4$ concentrations versus regression residuals; and $D$, standard normal quantiles versus regression residuals for the North Fork Ninnescah River upstream from Cheney Reservoir (site 07144780), south-central Kansas, 1999 through 2009

22. $\quad \mathrm{S}+{ }^{\circledR}$ output of regression model development using streamflow $(0)$ as an explanatory variable for sulfate (SO4) concentrations for the North Fork Ninnescah River upstream from Cheney Reservoir (site 07144780), south-central Kansas, 1999 through 2009

23. $\mathrm{S}+{ }^{\circledR}$ output graphs from simple linear regression analysis showing $A$, log-transformed streamflow ( 0 ) versus sulfate ( $\mathrm{SO}$ ) concentrations; $B$, computed versus actual SO4 concentrations; $C$, computed $\mathrm{SO} 4$ concentrations versus regression residuals; and $D$, standard normal quantiles versus regression residuals for the North Fork Ninnescah River upstream from Cheney Reservoir (site 07144780), south-central Kansas, 1999 through 2009. 
24. $S+{ }^{\circledR}$ output of regression model development using streamflow $(0)$ and specific conductance (SC) as explanatory variables for alkalinity (ALK) concentrations for the North Fork Ninnescah River upstream from Cheney Reservoir (site 07144780), south-central Kansas, 1999 through 2009.

25. $S+{ }^{\circledR}$ output graphs from simple linear regression analysis using streamflow (Q) and specific conductance (SC) as explanatory variables for alkalinity (ALK) concentrations showing $A$, computed versus actual ALK concentrations; $B$, computed log-transformed ALK concentrations versus regression residuals; and $C$, standard normal quantiles versus regression residuals for the North Fork Ninnescah River upstream from Cheney Reservoir (site 07144780), south-central Kansas, 1999 through 2009

26. $S+{ }^{\circledR}$ output of regression model development using streamflow (Q) and specific conductance (SC) as explanatory variables for bicarbonate ( $\mathrm{HCO}$ ) concentrations for the North Fork Ninnescah River upstream from Cheney Reservoir (site 07144780), south-central Kansas, 1999 through 2009.

27. $S+{ }^{\circledR}$ output graphs from simple linear regression analysis using streamflow (0) and specific conductance $(\mathrm{SC})$ as explanatory variables for bicarbonate ( $\mathrm{HCO}$ ) concentrations showing $A$, computed versus actual $\mathrm{HCO} 3$ concentrations; $B$, computed log-transformed $\mathrm{HCO} 3$ concentrations versus regression residuals, and $C$, standard normal quantiles versus regression residuals for the North Fork Ninnescah River upstream from Cheney Reservoir (site 07144780), south-central Kansas, 1999 through 2009

28. $\quad \mathrm{S}^{\circledR}$ output of regression model development using turbidity (TBY) as an explanatory variable for total suspended solids (TSS) concentrations for the North Fork Ninnescah River upstream from Cheney Reservoir (site 07144780), south-central Kansas, 1999 through 2009.

29. $\mathrm{S}+{ }^{\circledR}$ output graphs from simple linear regression analysis showing $A$, log-transformed turbidity (TBY) versus log-transformed total suspended solids (TSS) concentrations; $B$, computed versus actual TSS concentrations; $C$, computed log-transformed TSS concentrations versus regression residuals; and $D$, standard normal quantiles versus regression residuals for the North Fork Ninnescah River upstream from Cheney Reservoir (site 07144780), south-central Kansas, 1999 through 2009

30. $S+{ }^{\circledR}$ output of regression model development using streamflow $(0)$ as an explanatory variable for total suspended solids (TSS) concentrations for the North Fork Ninnescah River upstream from Cheney Reservoir (site 07144780), south-central Kansas, 1999 through 2009.

31. $\mathrm{S}+{ }^{\circledR}$ output graphs from simple linear regression analysis showing $A$, log-transformed streamflow ( 0 ) versus log-transformed total suspended solids (TSS) concentrations; $B$, computed versus actual TSS concentrations; $C$, computed log-transformed TSS concentrations versus regression residuals; and $D$, standard normal quantiles versus regression residuals for the North Fork Ninnescah River upstream from Cheney Reservoir (site 07144780), south-central Kansas, 1999 through 2009

32. $S+{ }^{\circledR}$ output of regression model development using streamflow $(0)$ and turbidity (TBY) as explanatory variables for suspended-sediment concentrations (SSC) for the North Fork Ninnescah River upstream from Cheney Reservoir (site 07144780), south-central Kansas, 1999 through 2009. 
33. $S+{ }^{\circledR}$ output graphs from simple linear regression analysis using streamflow (0) and turbidity (TBY) as explanatory variables for suspended-sediment concentrations (SSC) showing $A$, computed versus actual SSC concentrations; $B$, computed log-transformed SSC versus regression residuals; and $C$, standard normal quantiles versus regression residuals for the North Fork Ninnescah River upstream from Cheney Reservoir (site 07144780), south-central Kansas, 1999 through 2009

34. $S+{ }^{\circledR}$ output of regression model development using streamflow $(0)$ as an explanatory variable for suspended-sediment concentrations (SSC) for the North Fork Ninnescah River upstream from Cheney Reservoir (site 07144780), south-central Kansas, 1999 through 2009.

35. $\mathrm{S}+{ }^{\circledR}$ output graphs from simple linear regression analysis showing $A$, logtransformed streamflow ( 0 ) versus log-transformed suspended-sediment concentrations (SSC); $B$, computed versus actual SSC concentrations; $C$, computed log-transformed SSC versus regression residuals; and $D$, standard normal quantiles versus regression residuals for the North Fork Ninnescah River upstream from Cheney Reservoir (site 07144780), south-central Kansas, 1999 through 2009

36. $S+{ }^{\circledR}$ output of regression model development using season (SIN and COS) and turbidity (TBY) as explanatory variables for total nitrogen (TN) concentrations for the North Fork Ninnescah River upstream from Cheney Reservoir (site 07144780), south-central Kansas, 1999 through 2009.

37. $S+{ }^{\circledR}$ output graphs from simple linear regression analysis using season (SIN and COS) and turbidity (TBY) as explanatory variables for total nitrogen (TN) concentrations showing $A$, computed versus actual TN concentrations; $B$, computed log-transformed TN concentrations versus regression residuals; and $C$, standard normal quantiles versus regression residuals for the North Fork Ninnescah River upstream from Cheney Reservoir (site 07144780), south-central Kansas, 1999 through 2009

38. $\quad \mathrm{S}+{ }^{\circledR}$ output of regression model development using season (SIN and COS) and turbidity (TBY) as explanatory variables for total nitrogen (TN) concentrations for the North Fork Ninnescah River upstream from Cheney Reservoir (site 07144780), south-central Kansas, 1999 through 2009.

39. $S+{ }^{\circledR}$ output graphs from simple linear regression analysis using season (SIN and $\mathrm{COS}$ ) and streamflow ( 0 ) as explanatory variables for total nitrogen (TN) concentrations showing $A$, computed versus actual TN concentrations; $B$, computed log-transformed TN concentrations versus regression residuals; and $C$, standard normal quantiles versus regression residuals for the North Fork Ninnescah River upstream from Cheney Reservoir (site 07144780), south-central Kansas, 1999 through 2009

40. $S+{ }^{\circledR}$ output of regression model development using turbidity (TBY) as an explanatory variable for total Kjeldahl nitrogen (TKN) concentrations for the North Fork Ninnescah River upstream from Cheney Reservoir (site 07144780), south-central Kansas, 1999 through 2009.

41. $\mathrm{S}+{ }^{\circledR}$ output graphs from simple linear regression analysis showing $A$, log-transformed turbidity (TBY) versus log-transformed total Kjeldahl nitrogen (TKN) concentrations; $B$, computed versus actual TKN concentrations; $C$, computed log-transformed TKN concentrations versus regression residuals; and $D$, standard normal quantiles versus regression residuals for the North Fork Ninnescah River upstream from Cheney reservoir (site 07144780), south-central Kansas, 1999 through 2009 
42. $\quad S+{ }^{\circledR}$ output of regression model development using turbidity (TBY) and specific conductance (SC) as explanatory variables for organic nitrogen (ON) concentrations for the North Fork Ninnescah River upstream from Cheney Reservoir (site 07144780), south-central Kansas, 1999 through 2009.

43. $\mathrm{S}+{ }^{\circledR}$ output graphs from simple linear regression analysis using turbidity (TBY) and specific conductance (SC) as explanatory variables for organic nitrogen (ON) concentrations showing $A$, computed versus actual $0 \mathrm{~N}$ concentrations; $B$, computed $\mathrm{ON}$ concentrations versus regression residuals; and $C$, standard normal quantiles versus regression residuals for the North Fork Ninnescah River upstream from Cheney Reservoir (site 07144780), south-central Kansas, 1999 through 2009

44. $S+{ }^{\circledR}$ output of regression model development using season (SIN and COS) and turbidity (TBY) as explanatory variables for nitrate (NO3) concentrations for the North Fork Ninnescah River upstream from Cheney Reservoir (site 07144780), south-central Kansas, 1999 through 2009.

45. $S+{ }^{\circledR}$ output graphs from simple linear regression analysis using season (SIN and $\mathrm{COS}$ ) and turbidity (TBY) as explanatory variables for nitrate (NO3) concentrations showing $A$, computed versus actual NO3 concentrations; $B$, computed NO3 concentrations versus regression residuals; and $C$, standard normal quantiles versus regression residuals for the North Fork Ninnescah River upstream from Cheney Reservoir (site 07144780), south-central Kansas, 1999 through 2009.

46. $S+{ }^{\circledR}$ output of regression model development using season (SIN and COS) and streamflow ( 0 ) as explanatory variables for nitrate (NO3) concentrations for the North Fork Ninnescah River upstream from Cheney Reservoir (site 07144780), south-central Kansas, 1999 through 2009.

47. $S+{ }^{\circledR}$ output graphs from simple linear regression analysis using season (SIN and $\mathrm{COS}$ ) and streamflow ( 0 ) as explanatory variables for nitrate (NO3) concentrations showing $A$, computed versus actual NO3 concentrations; $B$, computed N03 concentrations versus regression residuals; and $C$, standard normal quantiles versus regression residuals for the North Fork Ninnescah River upstream from Cheney Reservoir (site 07144780), south-central Kansas, 1999 through 2009.

48. $S+{ }^{\circledR}$ output of regression model development using turbidity (TBY) as an explanatory variable for total phosphorus (TP) concentrations for the North Fork Ninnescah River upstream from Cheney Reservoir (site 07144780), south-central Kansas, 1999 through 2009

49. $\mathrm{S}+{ }^{\circledR}$ output graphs from simple linear regression analysis showing $A$, log-transformed turbidity (TBY) versus log-transformed total phosphorus (TP) concentrations; $B$, computed versus actual TP concentrations; $C$, computed log-transformed TP concentrations versus regression residuals; and $D$, standard normal quantiles versus regression residuals for the North Fork Ninnescah River upstream from Cheney Reservoir (site 07144780), south-central Kansas, 1999 through 2009

50. $S+{ }^{\circledR}$ output of regression model development using streamflow $(0)$ as an explanatory variable for total phosphorus (TP) concentrations for the North Fork Ninnescah River upstream from Cheney Reservoir (site 07144780), south-central Kansas, 1999 through 2009

51. $\mathrm{S}+{ }^{\circledR}$ output graphs from simple linear regression analysis showing $A$, log-transformed streamflow ( $Q$ ) versus total phosphorus (TP) concentrations; $B$, computed versus actual TP concentrations; $C$, computed TP concentrations versus regression residuals; and $D$, standard normal quantiles versus regression residuals for the North Fork Ninnescah River upstream from Cheney Reservoir (site 07144780), south-central Kansas, 1999 through 2009 
52. $\quad \mathrm{S}+{ }^{\circledR}$ output of regression model development using specific conductance (SC) as an explanatory variable for orthophosphate (OP) concentrations for the North Fork Ninnescah River upstream from Cheney Reservoir (site 07144780), south-central Kansas, 1999 through 2009

53. $\quad \mathrm{S}+{ }^{\circledR}$ output graphs from simple linear regression analysis showing $A$, specific conductance (SC) versus orthophosphate (OP) concentrations; $B$, computed versus actual $\mathrm{OP}$ concentrations; $C$, computed $\mathrm{OP}$ concentrations versus regression residuals; and $D$, standard normal quantiles versus regression residuals for the North Fork Ninnescah River upstream from Cheney Reservoir (site 07144780), south-central Kansas, 1999 through 2009.

54. $S+{ }^{\circledR}$ output of regression model development using turbidity (TBY) and specific conductance (SC) as explanatory variables for fecal coliform bacteria (FC) densities for the North Fork Ninnescah River upstream from Cheney Reservoir (site 07144780), south-central Kansas, 1999 through 2009.

55. $\quad \mathrm{S}+{ }^{\circledR}$ output graphs from simple linear regression analysis using turbidity (TBY) and specific conductance (SC) as explanatory variables for fecal coliform (FC) densities showing $A$, computed versus actual FC densities; $B$, computed log-transformed $F C$ densities versus regression residuals; and $C$, standard normal quantiles versus regression residuals for the North Fork Ninnescah River upstream from Cheney Reservoir (site 07144780), south-central Kansas, 1999 through 2009.

56. $S+{ }^{\circledR}$ output of regression model development using turbidity (TBY) and specific conductance (SC) as explanatory variables for Escherichia coli bacteria (EC) densities for the North Fork Ninnescah River upstream from Cheney Reservoir (site 07144780), south-central Kansas, 1999 through 2009...

57. $S+{ }^{\circledR}$ output graphs from simple linear regression analysis using turbidity (TBY) and specific conductance (SC) as explanatory variables for Escherichia coli bacteria (EC) densities showing $A$, computed versus actual EC densities; $B$, computed log-transformed EC densities versus regression residuals; and $C$, standard normal quantiles versus regression residuals for the North Fork Ninnescah River upstream from Cheney Reservoir (site 07144780), south-central Kansas, 1999 through 2009.

58. $S+{ }^{\circledR}$ output of regression model development using streamflow $(0)$ as an explanatory variable for Escherichia coli bacteria (EC) densities for the North Fork Ninnescah River upstream from Cheney Reservoir (site 07144780), south-central Kansas, 1999 through 2009

59. $\mathrm{S}+{ }^{\circledR}$ output graphs from simple linear regression analysis showing $A$, log-transformed streamflow ( 0 ) versus log-transformed Escherichia coli bacteria (EC) densities; $B$, computed versus actual EC densities; $C$, computed log-transformed $\mathrm{EC}$ densities versus regression residuals; and $D$, standard normal quantiles versus regression residuals for the North Fork Ninnescah River upstream from Cheney Reservoir (site 07144780), south-central Kansas, 1999 through 2009.

60. $\mathrm{S}+{ }^{\circledR}$ output of regression model development using turbidity (TBY) as the explanatory variable for total organic carbon (TOC) concentrations for the North Fork Ninnescah River upstream from Cheney Reservoir (site 07144780), south-central Kansas, 1999 through 2009.

61. $S+{ }^{\circledR}$ output graphs from simple linear regression analysis showing $A$, log-transformed turbidity (TBY) versus log-transformed total organic carbon (TOC) concentrations; $B$, computed versus actual TOC concentrations; $C$, computed log-transformed TOC concentrations versus regression residuals; and $D$, standard normal quantiles versus regression residuals for the North Fork Ninnescah River upstream from Cheney Reservoir (site 07144780), south-central Kansas, 1999 through 2009 


\section{Tables}

1. Christensen and others (2006), updated, and new regression models and summary statistics for continuous concentration computations for the North Fork Ninnescah River upstream from Cheney Reservoir (site 07144780), south-central Kansas, 1999 through 2009

2. Dissolved solids, calcium, magnesium, sodium, and potassium simple linear regression model datasets for the North Fork Ninnescah River upstream from Cheney Reservoir (site 07144780), south-central Kansas, 1999 through 2009.

3. Chloride and sulfate simple linear regression model datasets for the North Fork Ninnescah River upstream from Cheney Reservoir (site 07144780), south-central Kansas, 1999 through 2009

4. Alkalinity and bicarbonate simple linear regression model datasets for the North Fork Ninnescah River upstream from Cheney Reservoir (site 07144780), south-central Kansas, 1999 through 2009.

5. Total suspended solids simple linear regression model dataset for the North Fork Ninnescah River above Cheney Reservoir (site 07144780), south-central Kansas, 1999 through 2009

6. Suspended-sediment concentration simple linear regression model dataset for the North Fork Ninnescah River upstream from Cheney Reservoir (site 07144780), south-central Kansas, 1999 through 2009.

7. Total nitrogen simple linear regression model dataset for the North Fork Ninnescah River upstream from Cheney Reservoir (site 07144780), south-central Kansas, 1999 through 2009

8. Total Kjeldahl nitrogen simple linear regression model dataset for the North Fork Ninnescah River upstream from Cheney Reservoir (site 07144780), south-central Kansas, 1999 through 2009

9. Organic nitrogen simple linear regression model dataset for the North Fork Ninnescah River upstream from Cheney Reservoir (site 07144780), south-central Kansas, 1999 through 2009.

10. Nitrate simple linear regression model dataset for the North Fork Ninnescah River upstream from Cheney Reservoir (site 07144780), south-central Kansas, 1999 through 2009

11. Total phosphorus simple linear regression model dataset using for the North Fork Ninnescah River upstream from Cheney Reservoir (site 07144780), south-central Kansas, 1999 through 2009

12. Orthophosphate simple linear regression model dataset for the North Fork Ninnescah River upstream from Cheney Reservoir (site 07144780), south-central Kansas, 1999 through 2009

13. Fecal coliform bacteria simple linear regression model dataset for the North Fork Ninnescah River upstream from Cheney Reservoir (site 07144780), south-central Kansas, 1999 through 2009

14. Escherichia coli bacteria simple linear regression model dataset for the North Fork Ninnescah River upstream from Cheney Reservoir (site 07144780), south-central Kansas, 1999 through 2009

15. Total organic carbon simple linear regression model dataset for the North Fork Ninnescah River upstream from Cheney Reservoir (site 07144780), south-central Kansas, 1999 through 2009. 


\section{Conversion Factors}

Inch/Pound to SI

\begin{tabular}{lcl}
\hline \multicolumn{1}{c}{ Multiply } & By & \multicolumn{1}{c}{ To obtain } \\
\hline foot $(\mathrm{ft})$ & Length & meter $(\mathrm{m})$ \\
mile $(\mathrm{mi})$ & 0.3048 & kilometer $(\mathrm{km})$ \\
\hline \multicolumn{1}{c}{ Area } & \\
\hline square mile $\left(\mathrm{mi}^{2}\right)$ & 1.609 & square kilometer $\left(\mathrm{km}^{2}\right)$ \\
\hline & 2.590 & \\
\hline milliliter $(\mathrm{mL})$ & Volume & ounce, fluid $(\mathrm{oz})$ \\
cubic foot $\left(\mathrm{ft}^{3}\right)$ & 0.0338 & cubic decimeter $\left(\mathrm{dm}^{3}\right)$ \\
\hline & 28.32 & cubic meter per second $\left(\mathrm{m}^{3} / \mathrm{s}\right)$ \\
\hline cubic foot per second $(\mathrm{ft} 3 / \mathrm{s})$ & Flow rate & parts per million $(\mathrm{ppm})$ \\
milligram per liter $(\mathrm{mg} / \mathrm{L})$ & 0.02832 & \\
\hline & 1 & gram $(\mathrm{g})$ \\
\hline milligram $(\mathrm{mg})$ & Mass &
\end{tabular}

Temperature in degrees Celsius $\left({ }^{\circ} \mathrm{C}\right)$ may be converted to degrees Fahrenheit $\left({ }^{\circ} \mathrm{F}\right)$ as follows:

${ }^{\circ} \mathrm{F}=\left(1.8 \times^{\circ} \mathrm{C}\right)+32$

Temperature in degrees Fahrenheit $\left({ }^{\circ} \mathrm{F}\right)$ may be converted to degrees Celsius $\left({ }^{\circ} \mathrm{C}\right)$ as follows:

${ }^{\circ} \mathrm{C}=\left({ }^{\circ} \mathrm{F}-32\right) / 1.8$

Horizontal coordinate information is referenced to the North American Datum of 1983 (NAD 83).

Specific conductance is given in microsiemens per centimeter at 25 degrees Celsius $(\mu \mathrm{S} / \mathrm{cm}$ at $\left.25^{\circ} \mathrm{C}\right)$.

Concentrations of chemical constituents in water are given in milligrams per liter (mg/L). 


\section{Abbreviations}

\begin{tabular}{|c|c|}
\hline $\operatorname{adjr}^{2}$ & adjusted $R^{2}$ \\
\hline$C_{p}$ & Mallow's $C_{p}$ \\
\hline cooksD & Cook's distance \\
\hline Df & degrees of freedom \\
\hline dfits & change in fitted values \\
\hline F-statistic & ratio of the mean square of the regression to the estimated variance \\
\hline F Value & explained variance divided by unexplained variance \\
\hline Max & maximum \\
\hline Mean Sq & mean square \\
\hline Min & minimum \\
\hline Nvars & number of explanatory variables \\
\hline$p$-value & $\begin{array}{l}\text { probability of observing a test statistic that is as extreme or more extreme } \\
\text { than currently observed assuming that the null hypothesis is true }\end{array}$ \\
\hline $\operatorname{Pr}(\mathrm{F})$ & $\begin{array}{l}\text { probability of observing a test statistic that is as extreme or more extreme } \\
\text { than currently observed assuming that the null hypothesis is true }\end{array}$ \\
\hline $\operatorname{Pr}(>|t|)$ & $\begin{array}{l}\text { probability of observing a test statistic that is as extreme or more extreme } \\
\text { than currently observed assuming that the null hypothesis is true }\end{array}$ \\
\hline press & prediction error sum of squares \\
\hline R-squared & coefficient of determination $\left(R^{2}\right)$ \\
\hline resids & residuals \\
\hline Std. Error & standard error \\
\hline Stderr & standard error \\
\hline stnd.res & standardized residuals \\
\hline stud.res & studentized residuals \\
\hline Sum of $\mathrm{Sq}$ & sum of squares \\
\hline $\mathrm{t}$ value & coefficient divided by its standard error \\
\hline yhat & predicted values \\
\hline 10 & first quartile \\
\hline 30 & third quartile \\
\hline
\end{tabular}




\title{
Model Documentation for Relations Between Continuous Real-Time and Discrete Water-Quality Constituents in the North Fork Ninnescah River Upstream from Cheney Reservoir, South-Central Kansas, 1999-2009
}

\author{
By Mandy L. Stone, Jennifer L. Graham, and Jackline W. Gatotho
}

\begin{abstract}
Cheney Reservoir in south-central Kansas is one of the primary sources of water for the city of Wichita. The North Fork Ninnescah River is the largest contributing tributary to Cheney Reservoir. The U.S. Geological Survey has operated a continuous real-time water-quality monitoring station since 1998 on the North Fork Ninnescah River. Continuously measured water-quality physical properties include streamflow, specific conductance, $\mathrm{pH}$, water temperature, dissolved oxygen, and turbidity. Discrete water-quality samples were collected during 1999 through 2009 and analyzed for sediment, nutrients, bacteria, and other water-quality constituents. Regression models were developed to establish relations between discretely sampled constituent concentrations and continuously measured physical properties to estimate concentrations of those constituents of interest that are not easily measured in real time because of limitations in sensor technology and fiscal constraints.

Regression models were published in 2006 that were based on a different dataset collected during 1997 through 2003. This report updates those models using discrete and continuous data collected during January 1999 through December 2009. Models also were developed for five new constituents, including additional nutrient species and indicator bacteria. The water-quality information in this report is important to the city of Wichita because it allows the concentrations of many potential pollutants of interest, including nutrients and sediment, to be estimated in real time and characterized over conditions and time scales that would not be possible otherwise.
\end{abstract}

\section{Introduction}

Cheney Reservoir (fig. 1), located in south-central Kansas, was constructed between 1962 and 1965 by the Bureau of Reclamation, U.S. Department of the Interior, to provide a municipal water supply for the city of Wichita, downstream flood control, wildlife habitat, and recreational areas. From 1995 through 2010, water from Cheney Reservoir contributed between 51 and 69 percent of Wichita's water supply (Ziegler and others, 2010). Water-supply needs and reliance on Cheney Reservoir will continue to increase with ongoing population growth and urban development.

The U.S. Geological Survey (USGS), in cooperation with the city of Wichita, continuously has monitored water quality on the North Fork Ninnescah River upstream from Cheney Reservoir (USGS station 07144780; fig. 1) since October 1998. Streamflow has been measured continuously on the North Fork Ninnescah River above Cheney Reservoir since July 1965. Water budget analysis during 1997 through 2003 indicated that the North Fork Ninnescah River contributes about 70 percent of the water flowing into the reservoir (Christensen and others, 2006). Water-quality monitoring on the North Fork Ninnescah River provides continuous measures of specific conductance, $\mathrm{pH}$, water temperature, dissolved oxygen, and turbidity. Dozens of discrete water-quality samples have been collected at this site by USGS personnel and used to develop regression models establishing relations between continuously monitored water-quality physical properties and water-quality constituents of interest that are not monitored continuously.

\section{Purpose and Scope}

The purpose of this report is to update and document regression models that establish relations between continuous and discrete water-quality data collected from the North Fork Ninnescah River upstream from Cheney Reservoir (USGS station 07144780; fig. 1). Regression models originally were published by Christensen and others (2006) using data collected during 1997 through 2003 for 15 water-quality constituents, including total suspended solids, suspended sediment, dissolved solids and major ions, total Kjeldahl nitrogen, total phosphorus, orthophosphate, and fecal coliform bacteria. In this report, those regression models are updated using data 
collected through 2009, and additional models are developed for nitrate, organic nitrogen, Escherichia coli (E. coli) bacteria, and total organic carbon. Models were updated to be more representative of water-quality conditions at this site and to evaluate whether relations have changed. The updated models are intended to replace existing models. These models are useful for evaluating concentrations of water-quality constituents to compare with water-quality criteria, evaluating variability during rapidly changing conditions, computing loads and yields to assess constituent transport through the watershed, and for providing more accurate load estimates compared to the original models published in 2006 . The water-quality information in this report is important to the city of Wichita because it allows many potential pollutant concentrations of interest, including sediment and nutrient inputs, to be estimated in real time and characterized over conditions and time scales that would not otherwise be possible.

\section{Description of Study Area}

The Cheney Reservoir watershed is located in southcentral Kansas (fig. 1) and has a contributing drainage area of 933 square miles $\left(\mathrm{mi}^{2}\right)$. The North Fork Ninnescah River is the largest tributary to Cheney Reservoir. The North Fork Ninnescah River above Cheney Reservoir (USGS station 07144780), where continuous water-quality data have been collected since October 1998, has a drainage area of $734 \mathrm{mi}^{2}$.

Land use in the Cheney Reservoir watershed predominately is rural (fig. 1); less than 1 percent of the land use in the watershed is classified as urban. All agricultural crops, including wheat, comprise about 55 percent of land use in the watershed above the North Fork Ninnescah River site. About 25 percent of the North Fork Ninnescah River site's watershed is grassland and about 18 percent is conservation reserve program land (Peterson and others, 2005).

\section{Methods}

Continuous and discrete water-quality data were collected at one inflow site on the North Fork Ninnescah River (fig. 1; USGS station 07144780, North Fork Ninnescah River above Cheney Reservoir), hereinafter referred to as the inflow site. The North Fork Ninnescah River is the largest contributing tributary to Cheney Reservoir, and thus one of the main contributors to reservoir water quality. Discrete water-quality samples routinely have been collected since February 1996. Continuous and discrete water-quality data collected by the USGS at the inflow site from January 1999 through December 2009 were used to develop updated and new site-specific regression models.

\section{Continuous Water-Quality Monitoring}

Continuous water-quality data were collected from the inflow site and were recorded hourly. Streamflow was measured using standard USGS methods (Turnipseed and Sauer, 2010). The inflow site was equipped with a YSI 6600 Extended Deployment System water-quality monitor that measured specific conductance, $\mathrm{pH}$, water temperature, dissolved oxygen (YSI Clark cell or optical dissolved oxygen sensors), and turbidity (YSI model 6026 turbidity sensor). The YSI Clark cell dissolved-oxygen sensor was used from November 1998 through March 2008 and was replaced by the YSI optical dissolved-oxygen sensor in March 2008. The monitor was installed near the centroid of streamflow to best represent conditions across the width of the stream and was maintained in accordance with standard USGS procedures (Wilde, 2008; Wagner and others, 2006). Continuous streamflow and waterquality data were recorded hourly and are available on the USGS website at http://nrtwq.usgs.gov/ks.

The specific conductance, $\mathrm{pH}$, water temperature, and dissolved oxygen sensors have wide ranges of operation (Wagner and others, 2006) that were not exceeded in this study. The YSI model 6026 turbidity sensor instrument maximum $(1,700$ formazin nephelometric units, FNU) was not exceeded during 1999 through 2009 and the maximum reading recorded at this site during the study period was 1,700 FNU. Continuous data during the study period generally required corrections of less than 10 percent, which classifies the data quality rating as good according to established guidelines (Wagner and others, 2006). Time-series measurements occasionally were missing or deleted from the dataset because of equipment malfunction or excessive fouling caused by environmental conditions. During 1999 through 2009, less than 1 percent of the discharge record, 6 percent of the specific conductance record, 4 percent of the $\mathrm{pH}$ record, 3 percent of the temperature record, 8 percent of the dissolved oxygen record, and 7 percent of the turbidity record were missing or deleted. Missing and deleted data were because of issues with calibration of the Clark cell dissolved oxygen sensor, sensors becoming submerged in sand, sensors not having enough water to be submerged during low flow conditions, sensor fouling, data corrections greater than the maximum allowable 20 percent, and extremely cold temperatures causing icy conditions.

\section{Discrete Water-Quality Samples}

Discrete water-quality samples were collected over a range of streamflow conditions during January 1999 through December 2009 using depth- and width-integrating samplecollection techniques (Wilde, 2008; U.S. Geological Survey, 2006). Samples collected using this approach are representative of the average chemical composition of the stream crosssectional area. All water samples were analyzed for dissolved solids and major ions, alkalinity, suspended solids and sediment, nutrients (nitrogen and phosphorus species), indicator 


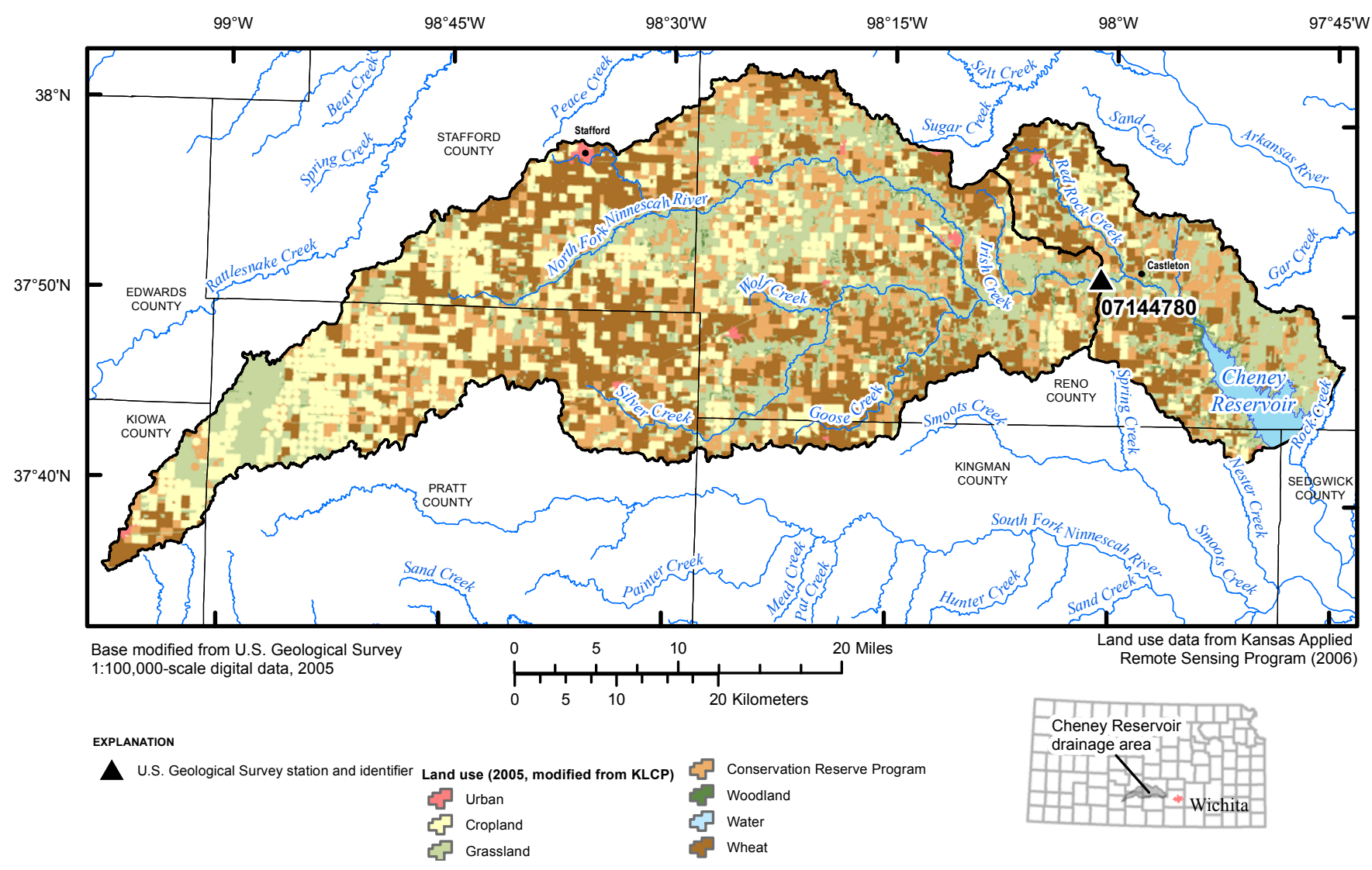

Figure 1. Location of continuous real-time water-quality monitoring station and land use in the Cheney Reservoir watershed.

bacteria, and organic carbon. Dissolved and suspended solids, major ions, alkalinity, nutrients (except for total Kjeldahl nitrogen), fecal coliform bacteria, and organic carbon were analyzed by the Wichita Municipal Water and Wastewater Laboratory in Wichita, Kansas according to standard methods (American Public Health Association and others, 1995). An incremental equivalence method was used for the alkalinity titrations. Bicarbonate concentrations were calculated by multiplying the alkalinity concentrations by 0.8202 (Rounds, 2012). Selected replicate samples were sent to the USGS National Water Quality Laboratory in Lakewood, Colorado and analyzed according to methods presented in Fishman and Friedman (1989). E. coli bacteria was analyzed at the USGS Wichita Field Office in Wichita, Kansas using methods described by Wilde (2008). Suspended sediment was analyzed at the USGS Iowa Sediment Laboratory in Iowa City, Iowa according to methods described in Guy (1969).

\section{Quality Assurance and Quality Control}

Replicate, standard reference, and blank samples were collected over a range of streamflow conditions as part of quality assurance/quality control (QA/QC). About 8 percent of discrete water-quality samples were QA/QC samples. Approximately 180 sequential replicate constituent pairs were collected during 1999 through 2009 for the inflow site. Replicate samples were analyzed to identify variability in sampling and analysis methods (Wilde, 2008). Relative percentage difference (RPD) was used to evaluate differences in analyte concentrations detected in replicate water samples. The RPD was calculated using the following equation:

$$
R P D=\left[|A-B| /\left(\frac{A+B}{2}\right)\right] \times 100
$$

where $A$ and $B$ are concentrations in each replicate pair. Replicate pairs with an RPD within 10 percent were considered acceptable for inorganic constituents (Ziegler and Combs, 1997). Replicate pairs with an RPD within 20 percent were considered acceptable for organic constituents (including total phosphorus), and RPDs within 50 percent were considered acceptable for bacterial analysis. The median RPD between all constituent replicate pairs was less than their respective acceptability limits. All constituent replicate pairs had median RPDs that were less than 5 percent, except for total Kjeldahl nitrogen (12 percent), total phosphorus (15 percent), E. coli (25 percent), and suspended sediment (6 percent). Larger RPDs generally occurred when the values were near the method detection limit. 
Approximately 65 sequential constituent replicate pairs were analyzed by the Wichita Municipal Water and Wastewater Laboratory and the USGS National Water Quality Laboratory. The median RPD between laboratories for ions was 6 percent. The median RPD between laboratories for nutrients was 12 percent. Larger nutrient RPDs generally occurred because of differences in laboratory method reporting levels and when the values were at or near the method reporting level.

Blank sample analysis included approximately 210 constituent concentrations. All constituents were below the method reporting level with the exception of ammonia. One ammonia value was 0.01 milligrams per liter $(\mathrm{mg} / \mathrm{L})$ above the method reporting level. Median blank bicarbonate concentration was $2.4 \mathrm{mg} / \mathrm{L}$. Median blank alkalinity concentration was $2.0 \mathrm{mg} / \mathrm{L}$.

Standard reference samples were analyzed by the Wichita Municipal Water and Wastewater Laboratory at least annually and submitted to the USGS Branch of Quality Systems for sample analysis and evaluation of laboratory performance. Median major ion constituent RPDs ranged from 1 to 6 percent and median nutrient constituent RPDs ranged from 3 to 5 percent during this study. Results are available at $h t t p: / / b q s$. usgs.gov/srs/.

Cross-sectional measurements were compared to the continuous measurements to provide verification that minimum bias occurred as a result of water-quality monitor location within the stream cross-section. The median RPD between cross-sectional and continuous monitor measurements was approximately 2 percent for all measurements. Larger differences (greater than 5 percent RPD) between cross-sectional and continuous monitor measurements occurred during stormwater runoff events when conditions were changing rapidly.

\section{Development of Regression Models to Compute Constituent Concentrations}

Models were developed using simple linear (ordinary least squares) regression analyses to relate discrete sample concentrations or densities of water-quality constituents to continuously measured water-quality physical properties (Helsel and Hirsch, 2002; Rasmussen and others, 2008). The methods used for the development of these models and quantifying uncertainty are described in detail in Rasmussen and others (2009). All data for this report were analyzed using TIBCO Spotfire $S+{ }^{\circledR} 8.1$ for Windows ${ }^{\circledR}$ statistical software (TIBCO Software, Inc., 2008).

To avoid false-positive quantification of a constituent, low concentrations are left-censored and reported as "less than" values by the laboratory (Childress and others, 1999). Two constituents had left-censored data: organic nitrogen (15 percent of samples) and orthophosphate (33 percent of samples). The left-censored data arbitrarily were assigned a value of one-half of the censoring level.
Although Christensen and others (2006) included discrete data collected in 1997 and 1998 in their regression analyses, these data were not included in the current analysis. Christensen and others (2006) used cross-sectional means of continuously measured physical properties as explanatory variables, whereas this current analysis uses continuously measured water-quality data after the Rasmussen and others (2009) protocol. Christensen and others (2006) also included discrete data collected by autosamplers as response variables; this report did not use autosampled data because the autosamples represented a relatively small part of the dataset and may not be representative of the average chemical composition of the stream cross-sectional area (Christensen and others, 2006; Rasmussen and others, 2008). Original models had numbers of discrete samples ranging from 20 to 127 , with a median of 27 (Christensen and others, 2006). The numbers of discrete samples for models in this report range from 22 to 61 , with a median of 54 .

All continuously measured variables and seasonal components (sine and cosine variables) were tested for significance ( $p$-value less than 0.05) for each response variable. Concomitant in-stream continuous measurements were used to correspond with discrete measurements as described in Rasmussen and others (2009). In-stream continuous data corresponding to each discrete sample were determined from time-series datasets by using time-weighted averages of continuous data values recorded immediately before, during, and after the discrete sample collection.

Outliers were identified and removed as described in Rasmussen and others (2009). Outliers in discrete samples primarily were removed when there was large heterogeneity in corresponding physical properties of cross-sectional data recorded during discrete sampling and when there were issues with nutrient laboratory analysis (such as an orthophosphate concentration being higher than the concomitant total phosphorus concentration). Overall, approximately 5 percent of the discrete-sample data were considered outliers and were removed from regression models. Three percent of the discrete-sample data was removed because of large heterogeneity in corresponding physical properties of cross-sectional data recorded during discrete sampling. One percent of the discrete-sample data was removed because of a large specific conductance value likely affected by road salt application. One percent of the discrete-sample data was removed because of laboratory analysis issues. Uncertainty in regression model predictions is unknown when the cross-sectional measurements vary greatly from the in situ measurements and when road salt is applied.

Regression models were evaluated based on diagnostic statistics $\left(R^{2}\right.$, coefficient of determination; Mallow's $C_{\mathrm{p}}$; $R M S E$, root mean square error; PRESS, prediction error sum of squares), patterns in residual plots, and the range and distribution of discrete and continuous data (Helsel and Hirsch, 2002). All linear models were considered for each constituent, and the best model for each constituent was selected to maximize the amount of variance in the response variable that 
is explained by the model (multiple $R^{2}$ for models with one explanatory variable and adjusted $R^{2}$ for models with more than one explanatory variable), that best fits the data (Mallow's $C_{\mathrm{p}}$ ), and that minimized heteroscedasticity (irregular scatter) in the residual plots and uncertainty associated with computed values (RMSE and PRESS). Model simplicity also was considered for model selection because, as more variables are included, the likelihood increases that the variability of the system is not described by the sampling dataset. A second significant explanatory variable was added to the model when doing so substantially increased $R^{2}$ and decreased Mallow's $C_{\mathrm{p}}$.

Mean square error (MSE) and RMSE were calculated for each model to assess the variance between predicted and observed values (Helsel and Hirsch, 2002). The model standard percentage error $(M S P E)$ was calculated as a percentage of the RMSE (Hardison, 1969). Because transformation of estimates back into original units results in a low biased estimate (Helsel and Hirsch, 2002), a bias correction factor $(B C F)$ was calculated for models with logarithmically transformed response variables (Duan, 1983). Uncertainty associated with regression-computed constituent concentrations was quantified using 90-percent prediction intervals (Helsel and Hirsch, 2002).

\section{Results of Regression Analysis for Selected Constituents}

Regression models for 15 constituents developed from data collected during 1997 through 2003 (Christensen and others, 2006) were updated and new models were developed for 5 additional constituents not described in Christensen and others (2006). The updated models were for dissolved solids, calcium, magnesium, sodium, chloride, potassium, sulfate, alkalinity, bicarbonate, total suspended solids, suspended sediment, total Kjeldahl nitrogen, total phosphorus, orthophosphate, and fecal coliform bacteria. The newly developed models were for the nutrient species total nitrogen, organic nitrogen, and nitrate; E. coli bacteria; and total organic carbon. Additional streamflow-based models of select constituents of interest were developed to allow computation of constituent concentrations when concomitant initial model real time data are unavailable. Streamflow-based models were developed for dissolved solids, sodium, chloride, sulfate, total suspended solids, suspended sediment, total nitrogen, nitrate, total phosphorus, and E. coli bacteria. Updated and newly developed models were developed from data collected during 1999 through 2009. Models are shown in table 1. Model datasets are presented in tables $2-15$ and TIBCO Spotfire $\mathrm{S}^{+}{ }^{\circledR}$ model $\left(\mathrm{S}^{{ }^{\circledR}}\right.$ ) statistical output is presented in figures 2-61 (see the Abbreviations list in the front of this report for definitions of abbreviations used in the figures).

Graphical $\mathrm{S}^{+}{ }^{\circledR}$ statistical output includes plots of the regression analysis for regression equations with one explanatory variable, computed versus measured ("actual") concentrations, a comparison of estimated ("fitted") concentrations and regression residuals ("residuals"), and a standard normal quantiles versus regression residuals plot. The plot of the fitted values and regression residuals indicates unexplained structure left in the residuals (TIBCO Software, Inc., 2008). The standard normal quantiles versus regression residuals plots the normal quantiles ("quantiles of standard normal") against the regression residuals ("residuals") and provides a visual test of the assumption that the model's errors are normally distributed (TIBCO Software, Inc., 2008).

In general, model forms and the amount of variance explained by the models was similar between the original (Christensen and others, 2006) and updated models (table 1). The model forms for most updated models remained unchanged. Dissolved solids, calcium, magnesium, sodium, chloride, potassium, and sulfate were strongly positively correlated with specific conductance; the calcium model included streamflow as an additional explanatory variable. On average, the updated ion models explained 9 percent more of the variance in ion concentrations compared to the original models (table 1). Actual (measured) versus computed plots of dissolved solids, sodium, and chloride using streamflow as an explanatory variable indicate that relations may be different at higher concentrations compared to lower concentrations suggesting limitations in the utility of the streamflow-based model for these constituents (figs. $5 B, 13 B, 17 B$ ).

The maximum $\mathrm{pH}$ for discrete water-quality samples associated with alkalinity titrations was 8.7. Alkalinity and bicarbonate were positively correlated with streamflow and specific conductance. The updated alkalinity model explained 6 percent more variance in alkalinity concentrations than the original model and the updated bicarbonate model explained 5 percent more variance than the original model (table 1).

Total suspended solids and suspended sediment were strongly positively correlated with turbidity. The updated suspended-sediment model also included streamflow as an explanatory variable and explained 5 percent more variance in suspended-sediment concentrations than the original model (table 1). The total suspended solids model that uses streamflow as an explanatory variable has a larger amount of variability when total suspended solids concentration is greater than about $150 \mathrm{mg} / \mathrm{L}$ than when total suspended solids concentration is less than about $150 \mathrm{mg} / \mathrm{L}$ (fig. 31B).

All nitrogen species and total phosphorus models included turbidity as an explanatory variable. Total nitrogen and nitrate models also included season as an explanatory variable. The updated total Kjeldahl nitrogen model explained 9 percent more variance in total Kjeldahl nitrogen concentrations than the original model (table 1). The organic nitrogen model also included specific conductance as an explanatory variable, and the orthophosphorus model had specific conductance as the explanatory variable. Fecal coliform and Escherichia coli bacteria models were positively related to turbidity and negatively related to specific conductance. The total organic carbon model was positively related to turbidity. 


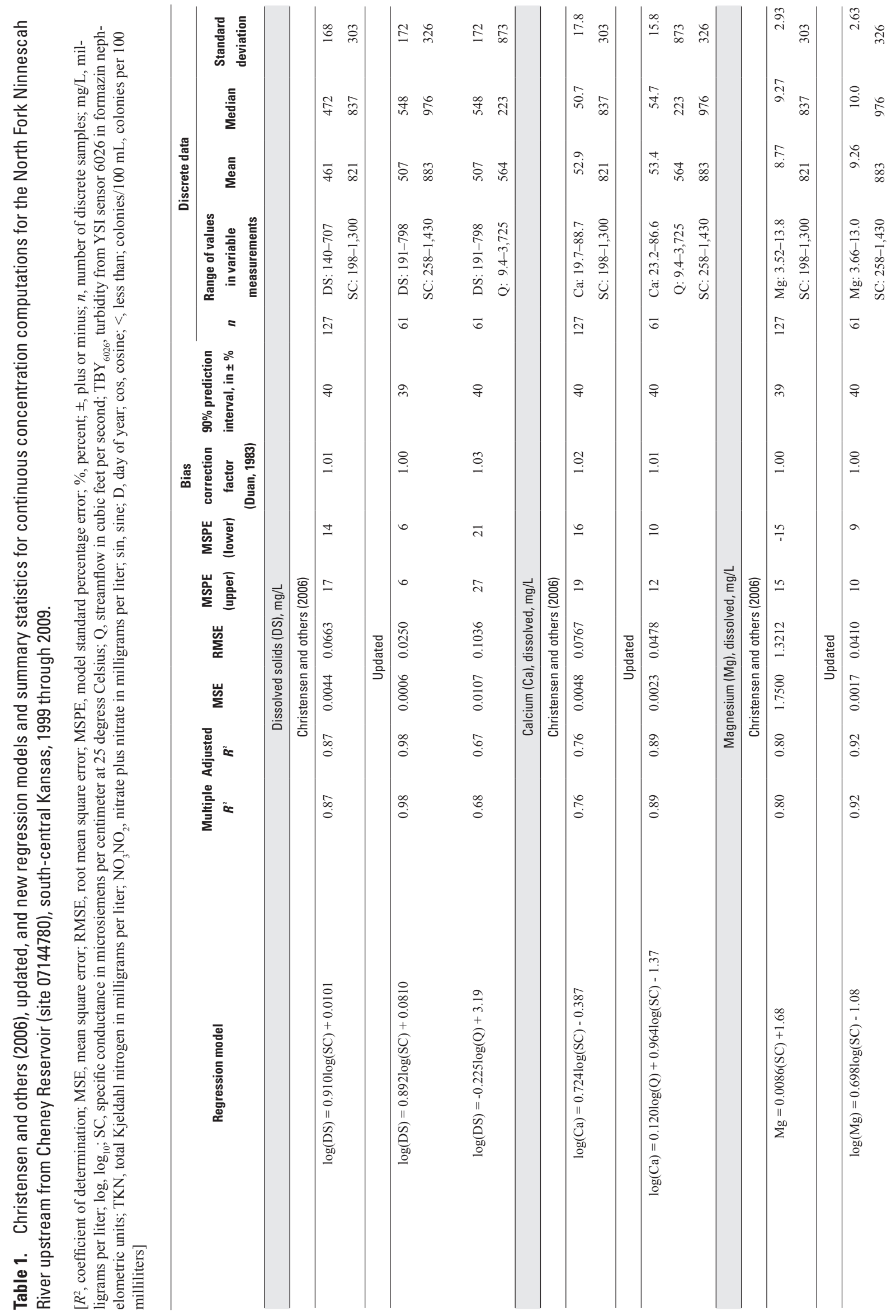



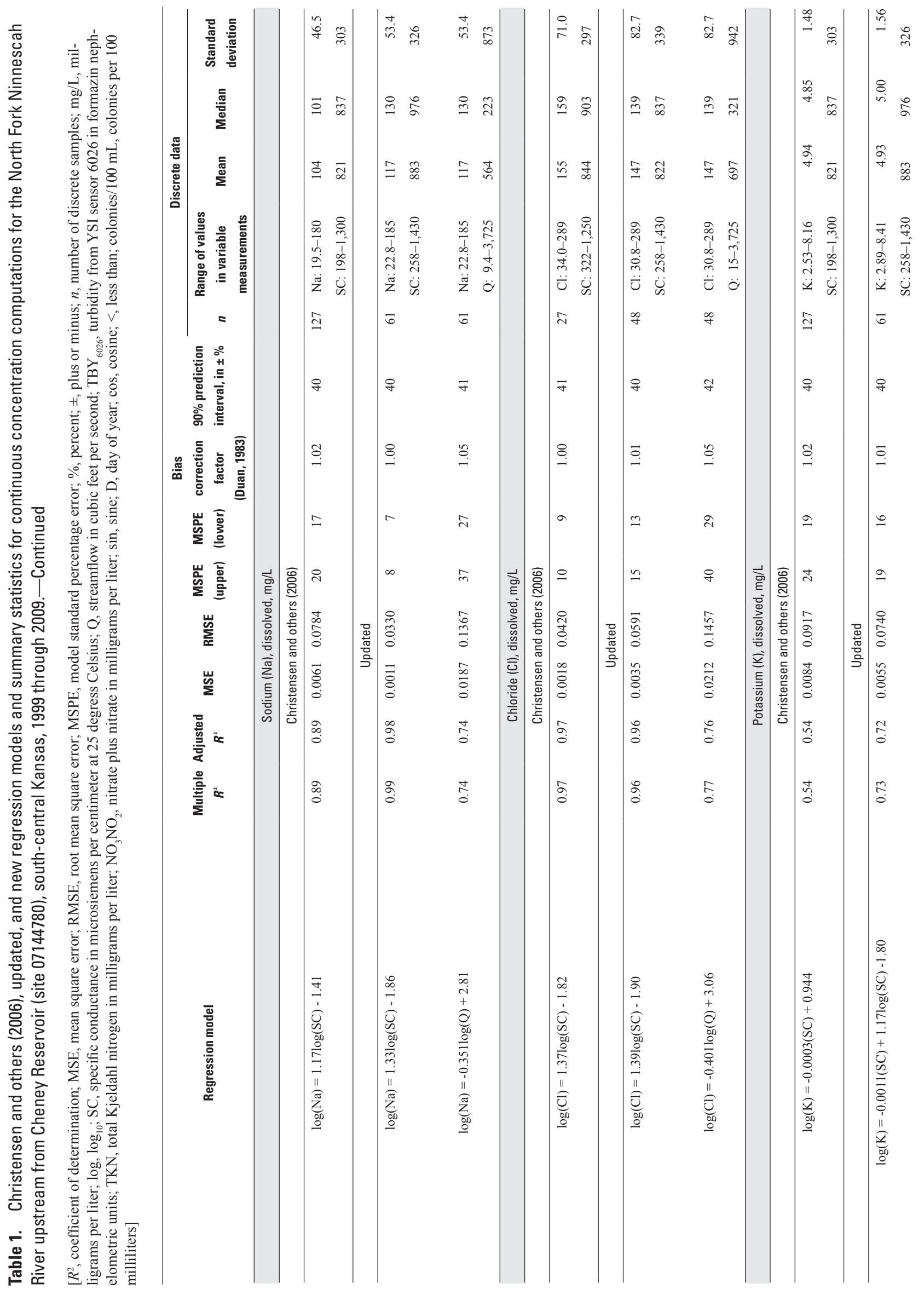

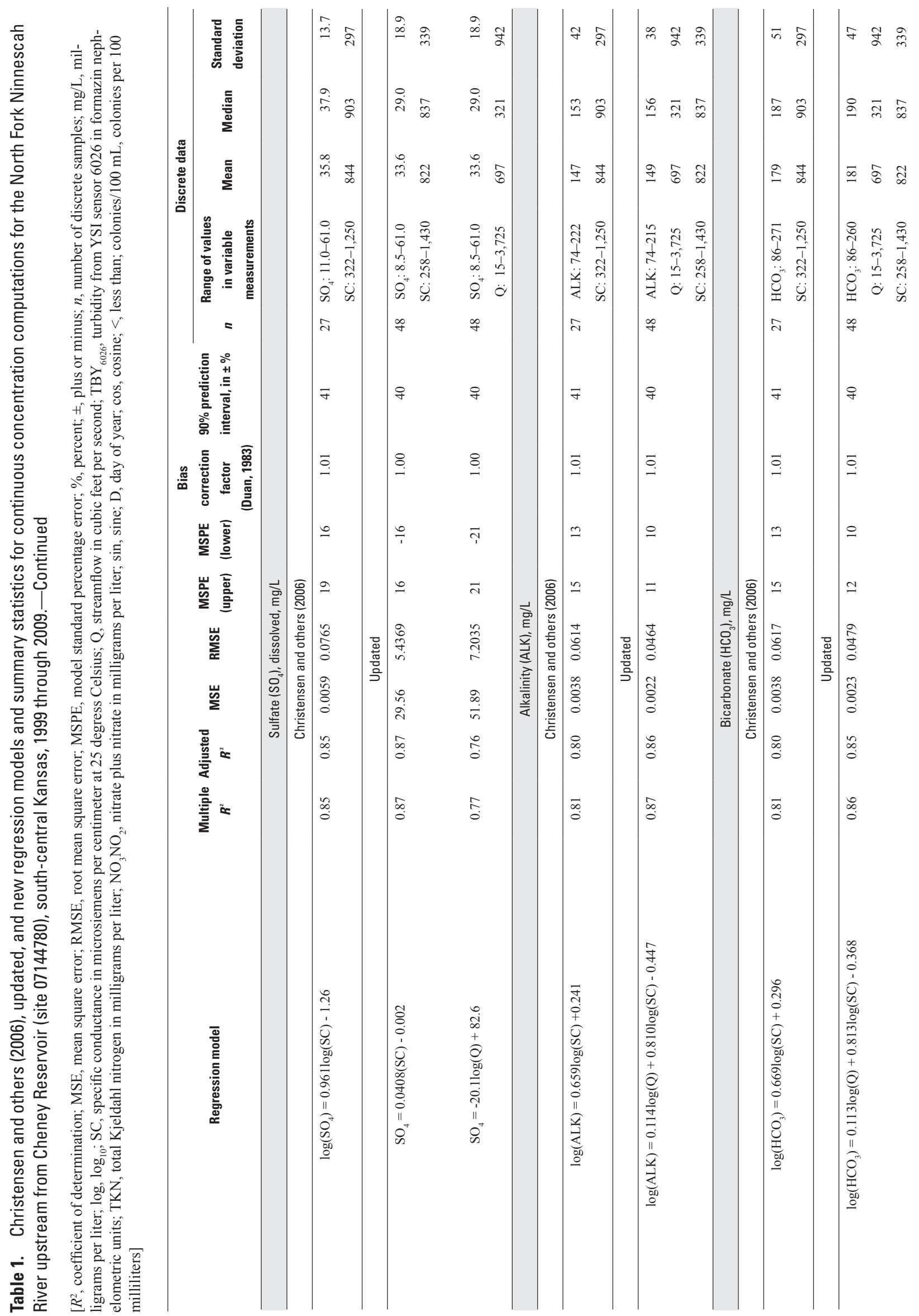

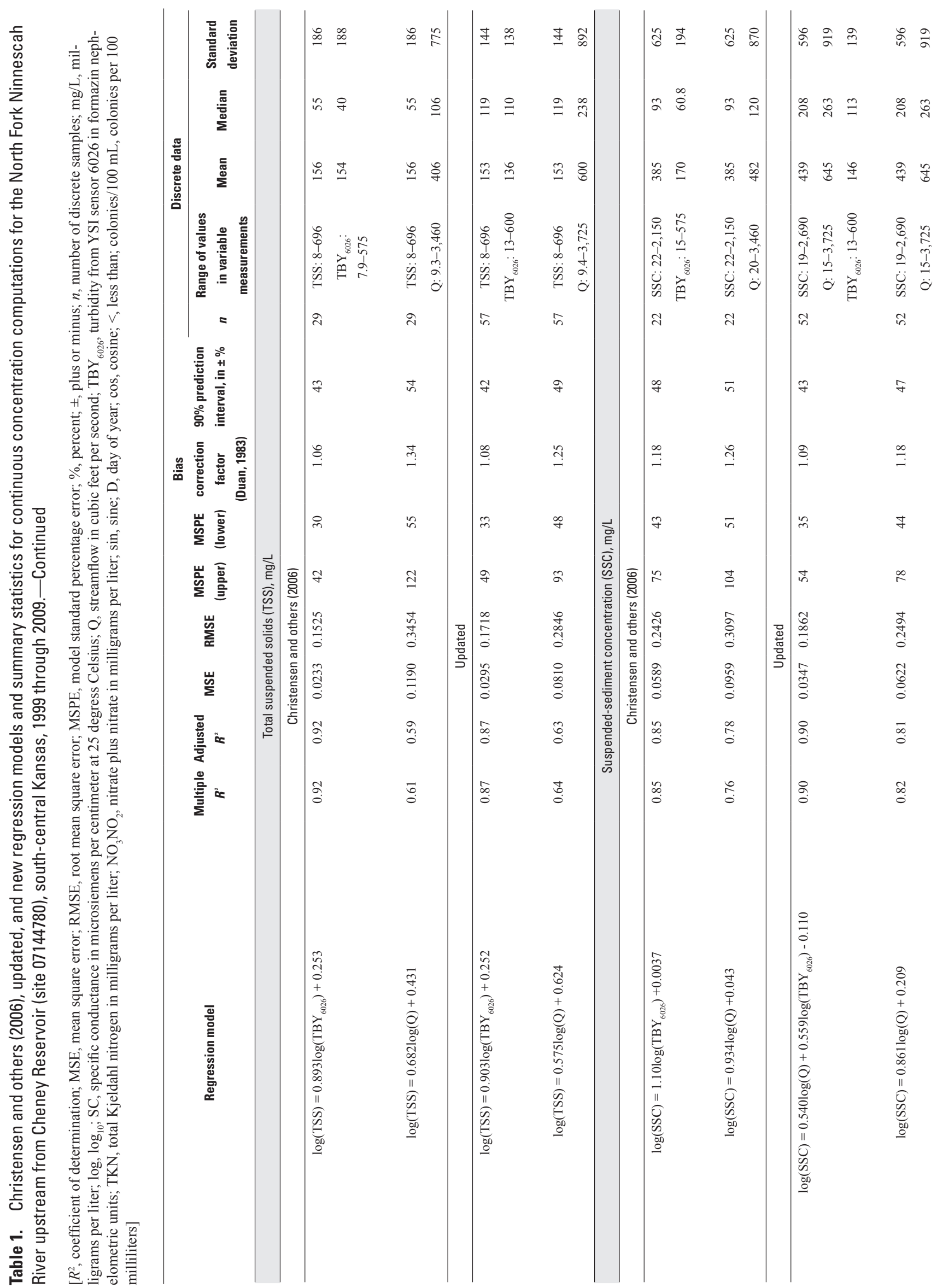


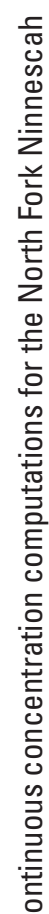

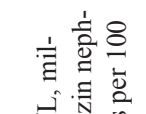

务

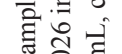

至

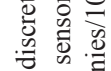

휴융

苯芯芯

$\therefore$ ?

解

के

空

+i

苟 ठ⿹

पे

뉴

î.

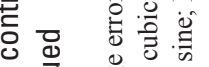

焉.

엉

过

를

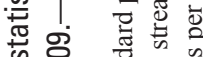

永余 焉

宸 동

के झ

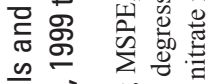

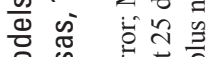

대

든

貿

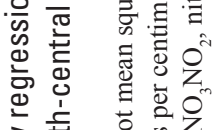

主

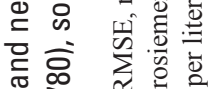

过 守完 है

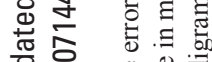

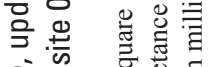

के 离苞.

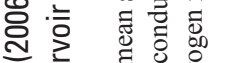

क

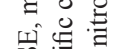

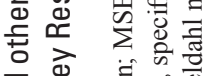

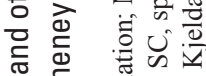

ธᄃ․ำ

¿

क्षे 过

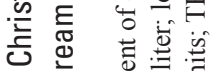

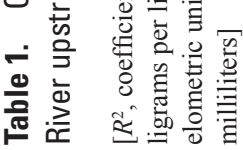

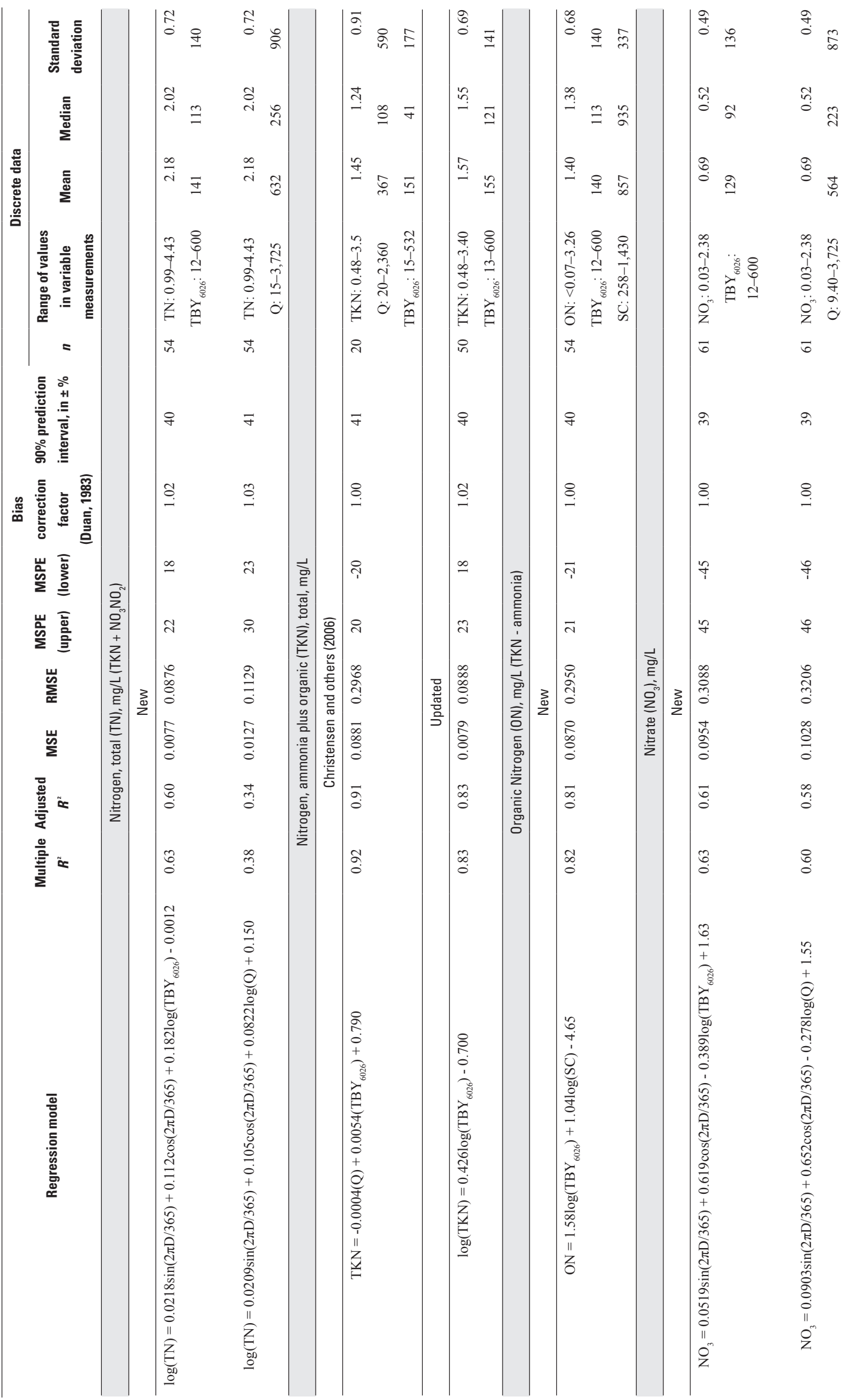


믈

$\stackrel{1}{=}$

흔

$\vec{g}$

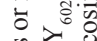
袁商

+i

茟

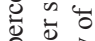

2.

$\therefore$ 这

व

迅. जी

论

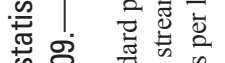

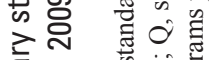

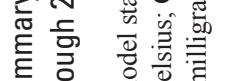

के

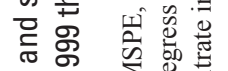

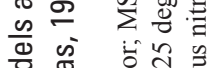

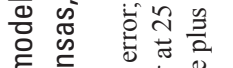

至垔

可

衣 d

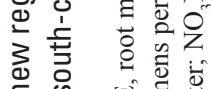

응 क्ष

守

䒕䓃

윽 용

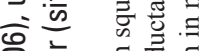

吕

心

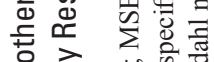

मे

它 离

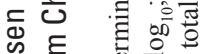

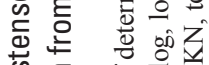

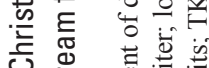

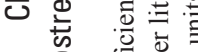

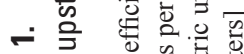

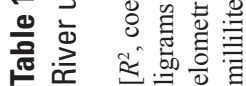

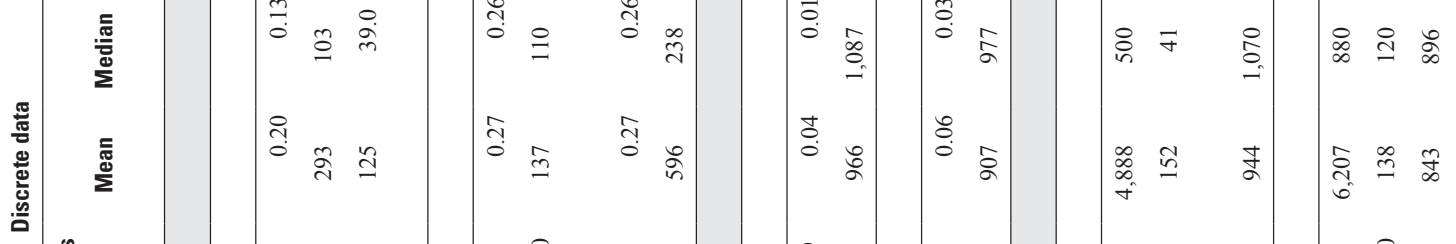

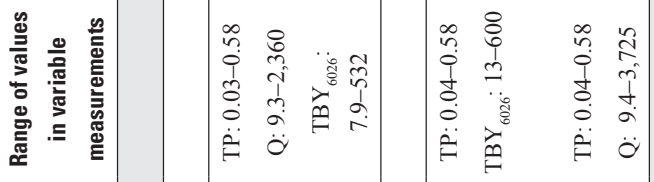

$=$ is in in

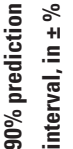

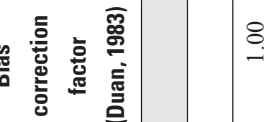

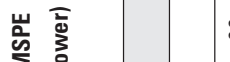

宸高
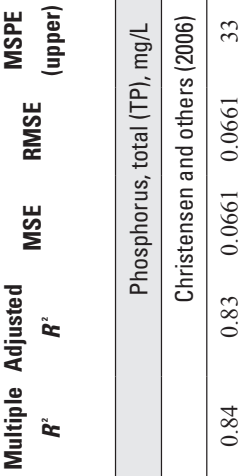

尊

宸
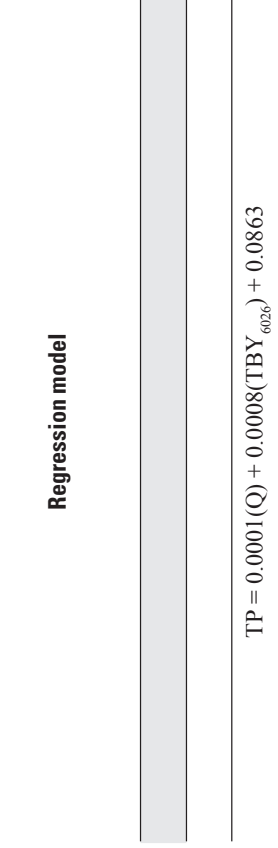

₹

$\stackrel{8}{\rightarrow}$

$\stackrel{0}{\circ}+\mid \stackrel{\circ}{\circ}$

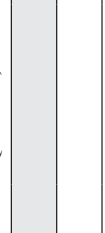

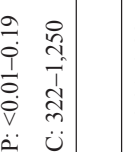

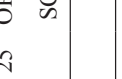

in

(3)

s.
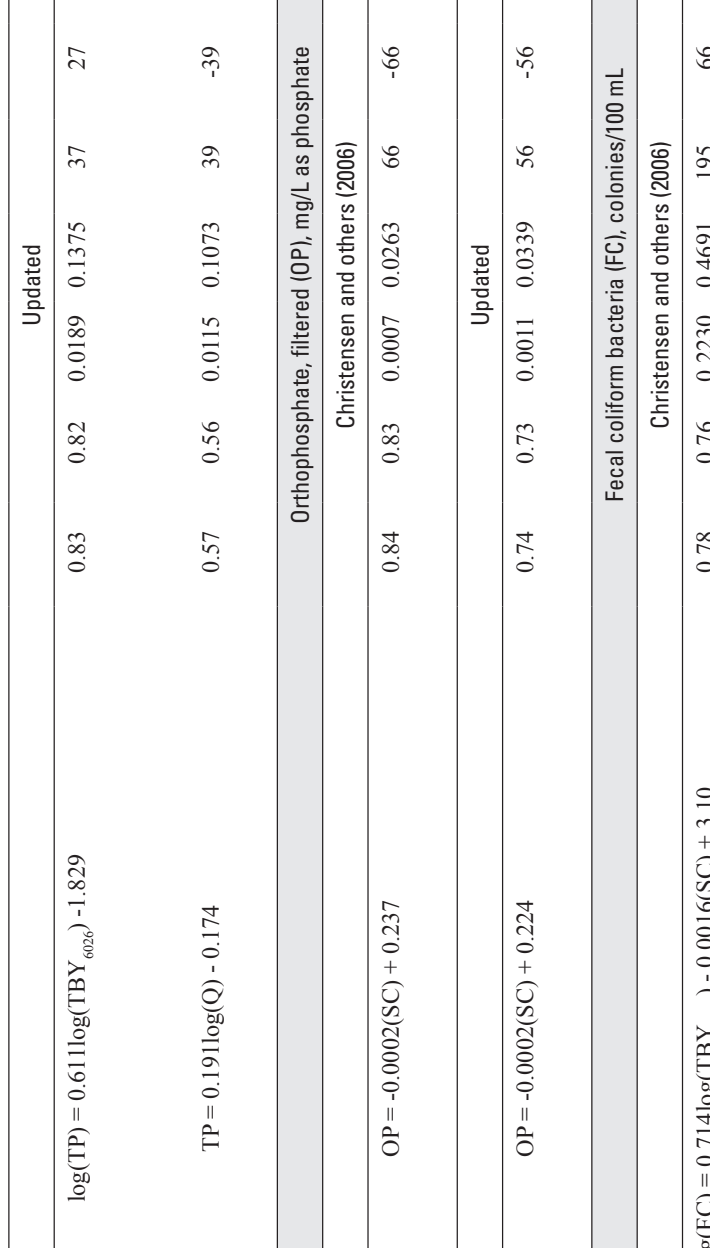

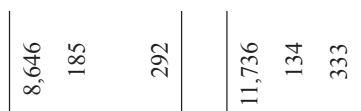

o

$\therefore$

5

독

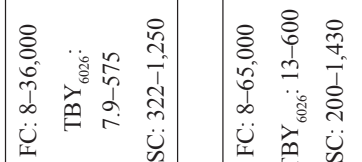




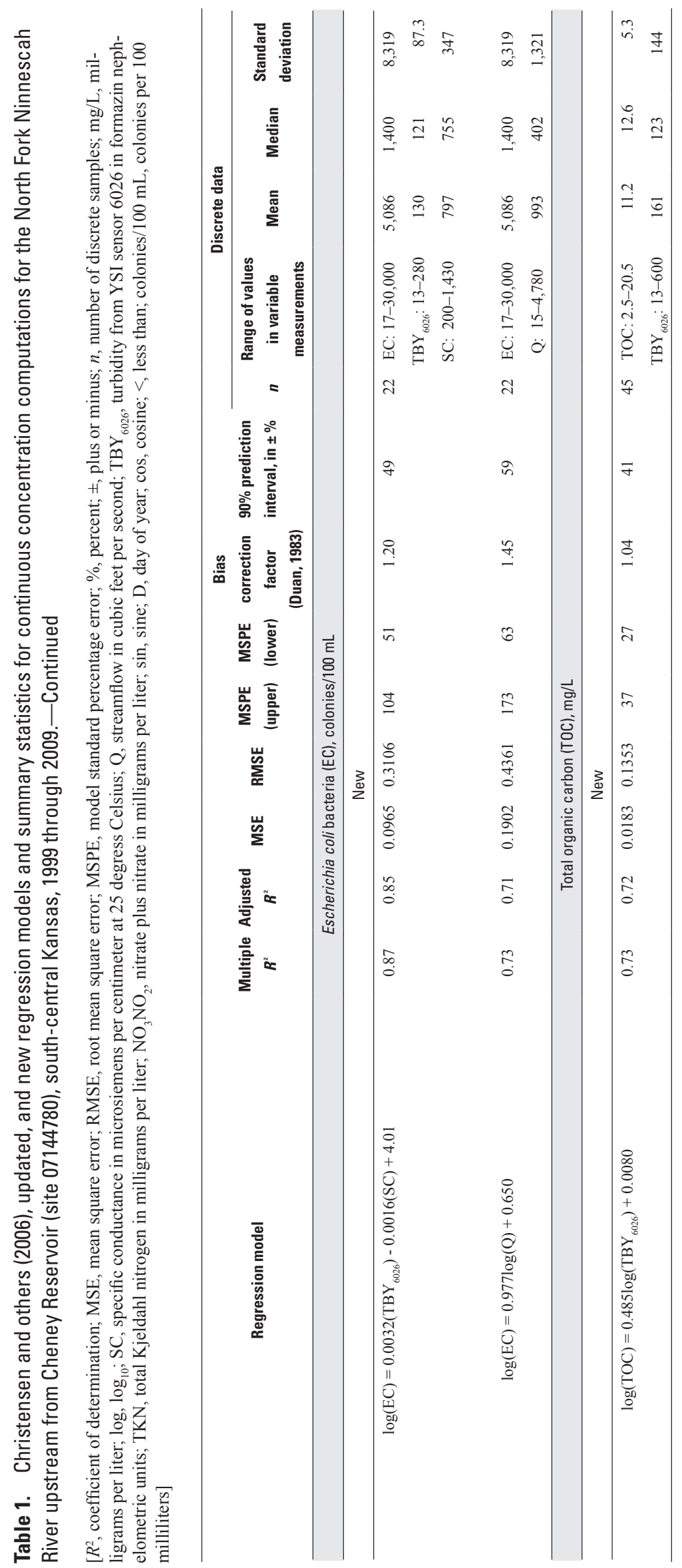


Table 2. Dissolved solids, calcium, magnesium, sodium, and potassium simple linear regression model datasets for the North Fork Ninnescah River upstream from Cheney Reservoir (site 07144780), south-central Kansas, 1999 through 2009.

[hh, hours; mm, minutes]

\begin{tabular}{|c|c|c|c|c|c|c|c|c|}
\hline Date & $\begin{array}{l}\text { Time, in } \\
\text { hhmm }\end{array}$ & $\begin{array}{c}\text { Specific } \\
\text { conductance, in } \\
\text { microsiemens } \\
\text { per centimeter } \\
\text { at } 25 \text { degrees } \\
\text { Celsius }\end{array}$ & $\begin{array}{l}\text { Streamflow, } \\
\text { in cubic feet } \\
\text { per second }\end{array}$ & $\begin{array}{l}\text { Dissolved } \\
\text { solids, in } \\
\text { milligrams } \\
\text { per liter }\end{array}$ & $\begin{array}{l}\text { Calcium, in } \\
\text { milligrams } \\
\text { per liter }\end{array}$ & $\begin{array}{c}\text { Magnesium, } \\
\text { in milligrams } \\
\text { per liter }\end{array}$ & $\begin{array}{c}\text { Sodium, in } \\
\text { milligrams } \\
\text { per liter }\end{array}$ & $\begin{array}{c}\text { Potassium, } \\
\text { in milligrams } \\
\text { per liter }\end{array}$ \\
\hline January 26, 1999 & 1150 & 1,195 & 106 & 677 & 84.9 & 11.7 & 164 & 2.89 \\
\hline May 24, 1999 & 1045 & 974 & 158 & 545 & 68.6 & 10.9 & 129 & 3.91 \\
\hline June 10, 1999 & 1200 & 1,125 & 86 & 641 & 59.8 & 12.3 & 155 & 2.92 \\
\hline June 25, 1999 & 1115 & 896 & 237 & 548 & 63.9 & 9.33 & 118 & 5.59 \\
\hline July 14, 1999 & 1120 & 1,078 & 63 & 618 & 56.3 & 11.1 & 159 & 3.47 \\
\hline September 22, 1999 & 1120 & 1,165 & 49 & 657 & 66.2 & 10.6 & 161 & 3.18 \\
\hline December 2, 1999 & 1035 & 1,230 & 62 & 684 & 69.0 & 10.8 & 163 & 3.28 \\
\hline February 25, 2000 & 1040 & 841 & 256 & 486 & 54.4 & 9.00 & 104 & 6.34 \\
\hline April 27, 2000 & 1045 & 1,180 & 110 & 658 & 75.8 & 12.0 & 147 & 2.99 \\
\hline May 25, 2000 & 1020 & 1,190 & 60 & 656 & 65.4 & 11.9 & 163 & 3.14 \\
\hline June 21, 2000 & 1200 & 1,120 & 47 & 642 & 50.6 & 10.2 & 155 & 3.41 \\
\hline July 26, 2000 & 1150 & 896 & 117 & 532 & 54.7 & 8.67 & 130 & 6.36 \\
\hline August 29, 2000 & 1100 & 1,080 & 9.4 & 581 & 45.9 & 11.1 & 162 & 3.83 \\
\hline September 28, 2000 & 1030 & 1,058 & 20 & 608 & 47.5 & 10.3 & 154 & 3.33 \\
\hline August 14, 2002 & 1135 & 398 & 347 & 239 & 30.2 & 4.70 & 45.0 & 6.29 \\
\hline March 18, 2003 & 1200 & 678 & 396 & 392 & 47.3 & 8.25 & 79.7 & 4.37 \\
\hline March 19, 2003 & 1220 & 342 & 2,245 & 224 & 27.6 & 4.99 & 34.5 & 5.81 \\
\hline April 21, 2003 & 1130 & 833 & 551 & 517 & 55.3 & 9.27 & 111 & 6.55 \\
\hline March 5, 2004 & 1210 & 445 & 1,968 & 355 & 35.1 & 5.79 & 50.1 & 5.91 \\
\hline May 14, 2004 & 1035 & 407 & 579 & 243 & 34.6 & 5.65 & 45.9 & 7.21 \\
\hline June 14, 2004 & 0945 & 576 & 238 & 331 & 39.3 & 6.64 & 63.4 & 8.41 \\
\hline September 8, 2004 & 1025 & 1,240 & 39 & 677 & 60.4 & 11.5 & 182 & 3.61 \\
\hline March 24, 2005 & 1015 & 1,060 & 381 & 621 & 69.0 & 12.4 & 144 & 5.17 \\
\hline May 16, 2005 & 1140 & 518 & 524 & 306 & 42.6 & 5.78 & 53.2 & 6.53 \\
\hline June 10, 2005 & 1055 & 258 & 1,100 & 191 & 23.2 & 4.43 & 22.8 & 6.00 \\
\hline June 13, 2005 & 0925 & 311 & 3,150 & 216 & 27.9 & 5.25 & 23.1 & 6.55 \\
\hline August 29, 2005 & 0935 & 707 & 256 & 420 & 52.2 & 6.68 & 83.0 & 8.05 \\
\hline March 2, 2006 & 0950 & 1,250 & 92 & 697 & 80.3 & 12.3 & 173 & 3.17 \\
\hline
\end{tabular}


Table 2. Dissolved solids, calcium, magnesium, sodium, and potassium simple linear regression model datasets for the North Fork Ninnescah River upstream from Cheney Reservoir (site 07144780), south-central Kansas, 1999 through 2009._Continued

[hh, hours; mm, minutes]

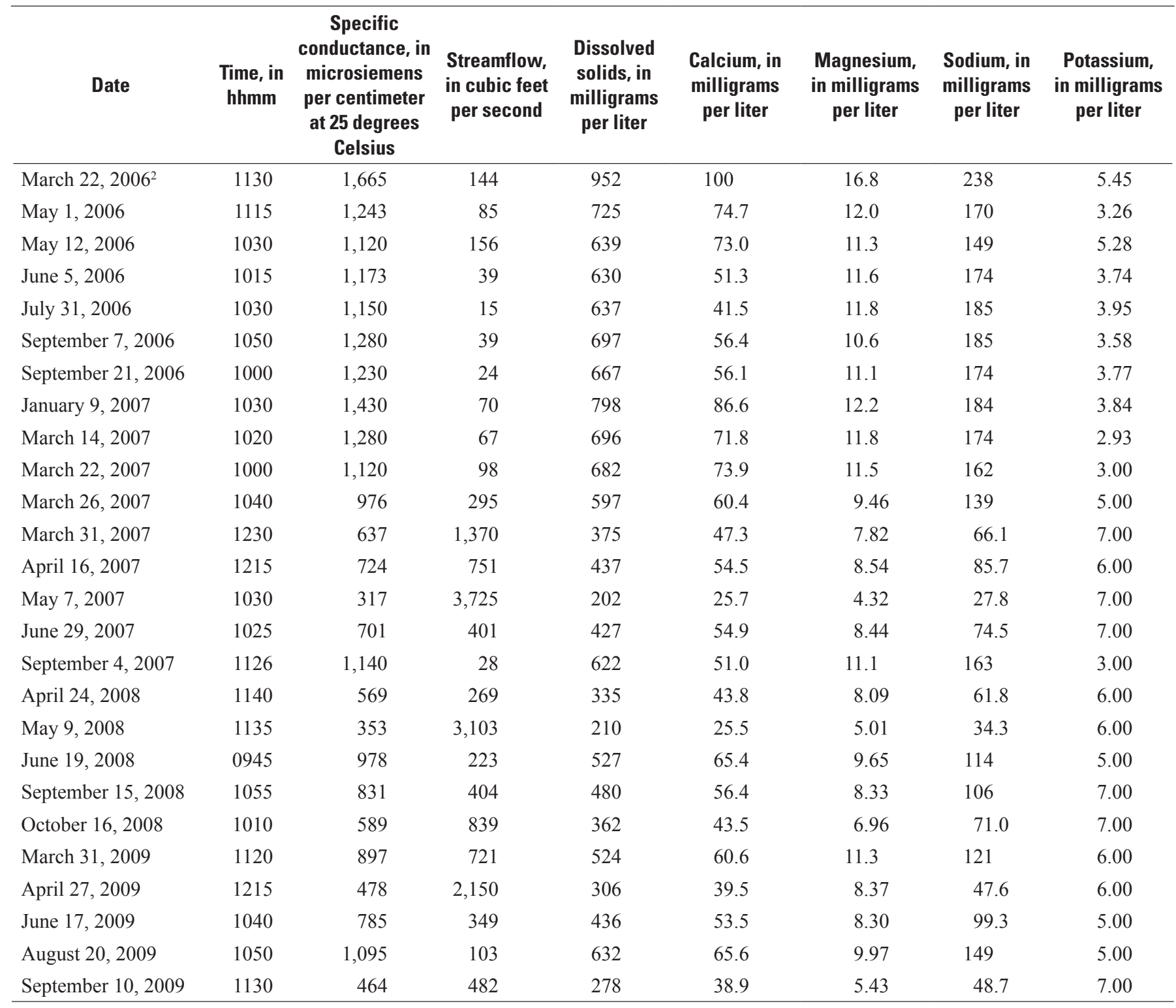

${ }^{1}$ Data point removed from final analysis because of atypically large heterogeneity in channel cross-sectional data during sample collection.

${ }^{2}$ Data point removed from final analysis because of the large specific conductance value likely affected by road salt application. 
Table 3. Chloride and sulfate simple linear regression model datasets for the North Fork Ninnescah River upstream from Cheney Reservoir (site 07144780), south-central Kansas, 1999 through 2009.

[hh, hours; mm, minutes]

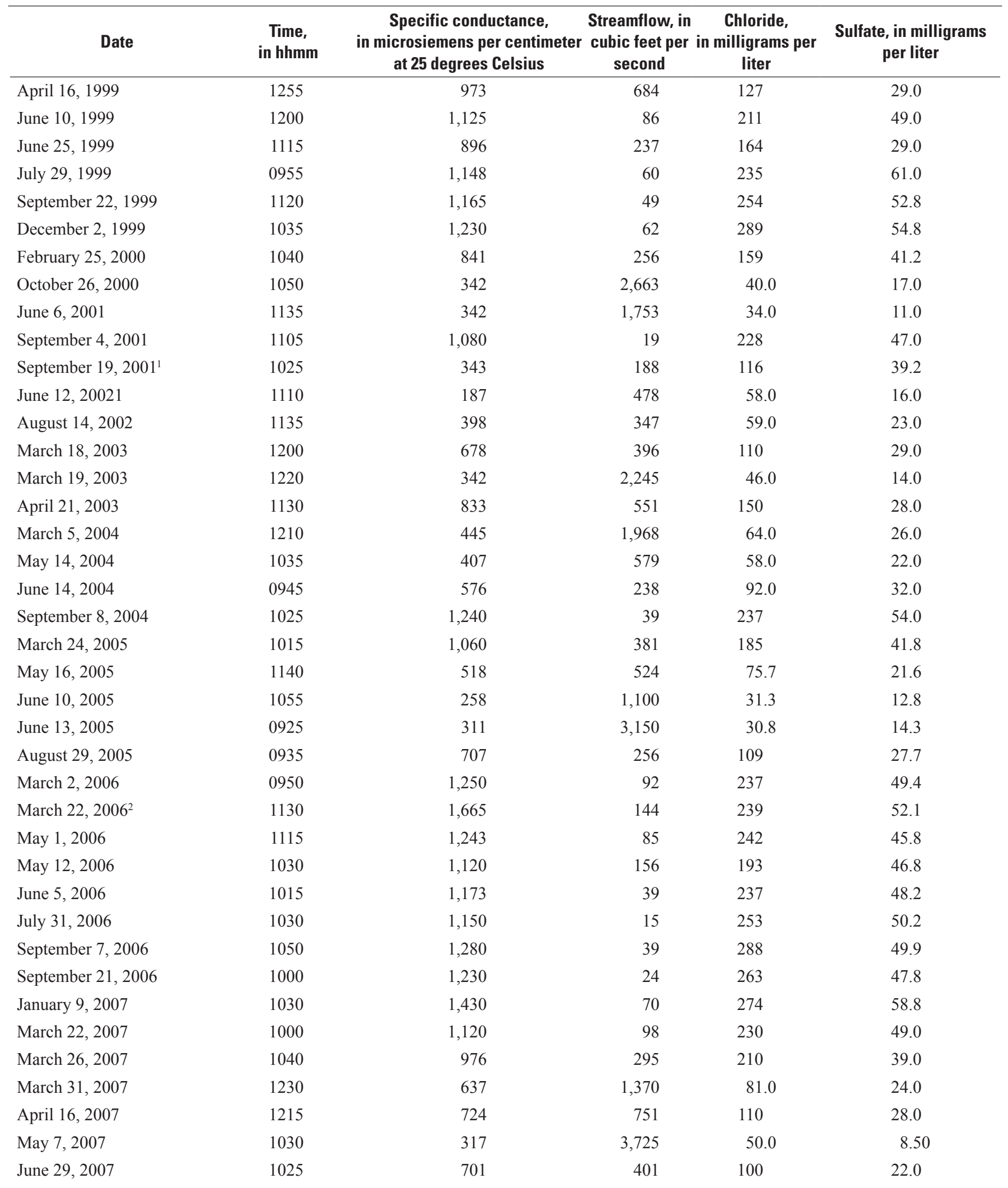


Table 3. Chloride and sulfate simple linear regression model datasets for the North Fork Ninnescah River upstream from Cheney Reservoir (site 07144780), south-central Kansas, 1999 through 2009._Continued

[hh, hours; mm, minutes]

\begin{tabular}{|c|c|c|c|c|c|}
\hline Date & $\begin{array}{c}\text { Time, } \\
\text { in hhmm }\end{array}$ & $\begin{array}{c}\text { Specific conductance, } \\
\text { in microsiemens per centimeter } \\
\text { at } 25 \text { degrees Celsius }\end{array}$ & $\begin{array}{l}\text { Streamflow, in } \\
\text { cubic feet per } \\
\text { second }\end{array}$ & $\begin{array}{l}\text { Chloride, } \\
\text { in milligrams per } \\
\text { liter }\end{array}$ & $\begin{array}{c}\text { Sulfate, in milligrams } \\
\text { per liter }\end{array}$ \\
\hline September 4, 2007 & 1126 & 1,140 & 28 & 240 & 46.0 \\
\hline April 24, 2008 & 1140 & 569 & 269 & 76.0 & 25.0 \\
\hline May 9, 2008 & 1135 & 353 & 3,103 & 40.0 & 12.0 \\
\hline June 19, 2008 & 0945 & 978 & 223 & 120 & 24.0 \\
\hline October 16, 2008 & 1010 & 589 & 839 & 96.0 & 21.0 \\
\hline March 31, 2009 & 1120 & 897 & 721 & 150 & 38.0 \\
\hline April 27, 2009 & 1215 & 478 & 2,150 & 48.0 & 16.0 \\
\hline June 17, 2009 & 1040 & 785 & 349 & 120 & 22.0 \\
\hline
\end{tabular}

${ }^{1}$ Data point removed from final analysis because of atypically large heterogeneity in channel cross-sectional data during sample collection.

${ }^{2}$ Data point removed from final analysis because of the large specific conductance value likely affected by road salt application. 
Table 4. Alkalinity and bicarbonate simple linear regression model datasets for the North Fork Ninnescah River upstream from Cheney Reservoir (site 07144780), south-central Kansas, 1999 through 2009.

[hh, hours; mm, minutes]

\begin{tabular}{|c|c|c|c|c|c|}
\hline Date & Time, in hhmm & $\begin{array}{l}\text { Streamflow, in cubic } \\
\text { feet per second }\end{array}$ & $\begin{array}{c}\text { Specific } \\
\text { conductance, in } \\
\text { microsiemens per cen- } \\
\text { timeter at } 25 \text { degrees } \\
\text { Celsius }\end{array}$ & $\begin{array}{l}\text { Alkalinity, in } \\
\text { milligrams per liter }\end{array}$ & $\begin{array}{l}\text { Bicarbonate, in } \\
\text { milligrams per liter }\end{array}$ \\
\hline April 16, 1999 & 1255 & 684 & 973 & 179 & 220 \\
\hline June 10, 1999 & 1200 & 86 & 1,125 & 176 & 220 \\
\hline July 29, 1999 & 0955 & 60 & 1,148 & 172 & 210 \\
\hline September 22, 1999 & 1120 & 49 & 1,165 & 182 & 220 \\
\hline December 2, 1999 & 1035 & 62 & 1,230 & 192 & 230 \\
\hline February 25, 2000 & 1040 & 256 & 841 & 153 & 190 \\
\hline October 26,2000 & 1050 & 2,663 & 342 & 74.0 & 86.0 \\
\hline June $12,2002^{1}$ & 1110 & 478 & 187 & 74.0 & 90.0 \\
\hline August 14, 2002 & 1135 & 347 & 398 & 80.0 & 98.0 \\
\hline March 18, 2003 & 1200 & 396 & 678 & 143 & 170 \\
\hline March 19, 2003 & 1220 & 2,245 & 342 & 89.0 & 110 \\
\hline April 21, 2003 & 1130 & 551 & 833 & 174 & 210 \\
\hline March 5, 2004 & 1210 & 1,968 & 445 & 98.0 & 120 \\
\hline May 14, 2004 & 1035 & 579 & 407 & 104 & 130 \\
\hline June 14, 2004 & 0945 & 238 & 576 & 120 & 150 \\
\hline March 2, 2006 & 0950 & 92 & 1,250 & 202 & 250 \\
\hline March 22, 2006² & 1130 & 144 & 1,665 & 230 & 280 \\
\hline May 1, 2006 & 1115 & 85 & 1,243 & 200 & 240 \\
\hline May 12, 2006 & 1030 & 156 & 1,120 & 195 & 240 \\
\hline June 5, 2006 & 1015 & 39 & 1,173 & 144 & 180 \\
\hline July 31, 2006 & 1030 & 15 & 1,150 & 121 & 150 \\
\hline September 7, 2006 & 1050 & 39 & 1,280 & 152 & 180 \\
\hline September 21, 2006 & 1000 & 24 & 1,230 & 159 & 190 \\
\hline January 9, 2007 & 1030 & 70 & 1,430 & 215 & 260 \\
\hline March 22, 2007 & 1000 & 98 & 1,120 & 196 & 240 \\
\hline March 26, 2007 & 1040 & 295 & 976 & 160 & 200 \\
\hline March 31, 2007 & 1230 & 1,370 & 637 & 149 & 180 \\
\hline April 16, 2007 & 1215 & 751 & 724 & 164 & 200 \\
\hline May 7, 2007 & 1030 & 3,725 & 317 & 90.0 & 110 \\
\hline
\end{tabular}


Table 4. Alkalinity and bicarbonate simple linear regression model datasets for the North Fork Ninnescah River upstream from Cheney Reservoir (site 07144780), south-central Kansas, 1999 through 2009._-Continued

[hh, hours; mm, minutes]

\begin{tabular}{|c|c|c|c|c|c|}
\hline Date & Time, in hhmm & $\begin{array}{l}\text { Streamflow, in cubic } \\
\text { feet per second }\end{array}$ & $\begin{array}{c}\text { Specific } \\
\text { conductance, in } \\
\text { microsiemens per cen- } \\
\text { timeter at } 25 \text { degrees } \\
\text { Celsius }\end{array}$ & $\begin{array}{l}\text { Alkalinity, in } \\
\text { milligrams per liter }\end{array}$ & $\begin{array}{l}\text { Bicarbonate, in } \\
\text { milligrams per liter }\end{array}$ \\
\hline June 29, 2007 & 1025 & 401 & 701 & 170 & 210 \\
\hline September 4, 2007 & 1126 & 28 & 1,140 & 158 & 190 \\
\hline May 9, 2008 & 1135 & 3,103 & 353 & 92.0 & 110 \\
\hline June 19, 2008 & 945 & 223 & 978 & 186 & 230 \\
\hline September 15, 2008 & 1055 & 404 & 831 & 144 & 180 \\
\hline October 16, 2008 & 1010 & 839 & 589 & 132 & 160 \\
\hline March 31, 2009 & 1120 & 721 & 897 & 174 & 210 \\
\hline September 10, 2009 & 1130 & 482 & 464 & 104 & 130 \\
\hline
\end{tabular}

${ }^{1}$ Data point removed from final analysis because of atypically large heterogeneity in channel cross-sectional data during sample collection.

${ }^{2}$ Data point removed from final analysis because of the large specific conductance value likely affected by road salt application. 
Table 5. Total suspended solids simple linear regression model dataset for the North Fork Ninnescah River above Cheney Reservoir (site 07144780), south-central Kansas, 1999 through 2009.

[hh, hours; mm, minutes]

\begin{tabular}{|c|c|c|c|c|}
\hline Date & Time, in hhmm & $\begin{array}{l}\text { Turbidity, in formazin } \\
\text { nephelometric units }\end{array}$ & $\begin{array}{l}\text { Streamflow, in cubic } \\
\text { feet per second }\end{array}$ & $\begin{array}{c}\text { Total suspended } \\
\text { solids, in milligrams } \\
\text { per liter }\end{array}$ \\
\hline January 26, 1999 & 1150 & 21 & 106 & 17 \\
\hline April 16, 1999 & 1255 & 128 & 684 & 309 \\
\hline May 13, 1999 & 1025 & 15 & 98 & 55 \\
\hline May 24, 1999 & 1045 & 138 & 158 & 119 \\
\hline June 10, 1999 & 1200 & 32 & 86 & 61 \\
\hline June 25, 1999 & 1115 & 120 & 237 & 148 \\
\hline July 29, 1999 & 0955 & 56 & 60 & 48 \\
\hline August 12, 1999 & 1035 & 51 & 43 & 35 \\
\hline August 26, 1999 & 1050 & 27 & 34 & 21 \\
\hline September 22, 1999 & 1120 & 22 & 49 & 30 \\
\hline December 2, 1999 & 1035 & 18 & 62 & 25 \\
\hline February 25, 2000 & 1040 & 272 & 256 & 422 \\
\hline April 27, 2000 & 1045 & 13 & 110 & 27 \\
\hline May 25,2000 & 1020 & 27 & 60 & 38 \\
\hline June 21,2000 & 1200 & 45 & 47 & 55 \\
\hline July 26, 2000 & 1150 & 123 & 117 & 142 \\
\hline August 29, 2000 & 1100 & 13 & 9.4 & 15 \\
\hline September 28, 2000 & 1030 & 22 & 20 & 8 \\
\hline October 26, 2000 & 1050 & 320 & 2,663 & 162 \\
\hline June 6, 2001 & 1135 & 250 & 1,753 & 212 \\
\hline September $19,2001^{1}$ & 1025 & 1,335 & 188 & 357 \\
\hline June $12,2002^{1}$ & 1110 & 965 & 478 & 582 \\
\hline August 14, 2002 & 1135 & 435 & 347 & 264 \\
\hline March 18, 2003 & 1200 & 600 & 396 & 696 \\
\hline March 19, 2003 & 1220 & 580 & 2,245 & 476 \\
\hline April 21, 2003 & 1130 & 130 & 551 & 124 \\
\hline March 5, 2004 & 1210 & 475 & 1,968 & 375 \\
\hline May 14, 2004 & 1035 & 210 & 579 & 100 \\
\hline June 14, 2004 & 0945 & 120 & 238 & 162 \\
\hline March 24, 2005 & 1015 & 105 & 381 & 120 \\
\hline May 16, 2005 & 1140 & 115 & 524 & 128 \\
\hline June 10, 2005 & 1055 & 240 & 1,100 & 250 \\
\hline June 13, 2005 & 0925 & 125 & 3,150 & 145 \\
\hline August 29, 2005 & 0935 & 140 & 256 & 172 \\
\hline March 2, 2006 & 0950 & 14 & 92 & 21 \\
\hline March 22, 2006 & 1130 & 71 & 144 & 87 \\
\hline June 5, 2006 & 1015 & 48 & 39 & 75 \\
\hline July 31, 2006 & 1030 & 31 & 15 & 24 \\
\hline September 7, 2006 & 1050 & 25 & 39 & 29 \\
\hline September 21, 2006 & 1000 & 13 & 24 & 15 \\
\hline
\end{tabular}


Table 5. Total suspended solids simple linear regression model dataset for the North Fork Ninnescah River above Cheney Reservoir (site 07144780), south-central Kansas, 1999 through 2009._Continued

$[\mathrm{hh}$, hours; mm, minutes]

\begin{tabular}{|c|c|c|c|c|}
\hline Date & Time, in hhmm & $\begin{array}{l}\text { Turbidity, in formazin } \\
\text { nephelometric units }\end{array}$ & $\begin{array}{l}\text { Streamflow, in cubic } \\
\text { feet per second }\end{array}$ & $\begin{array}{c}\text { Total suspended } \\
\text { solids, in milligrams } \\
\text { per liter }\end{array}$ \\
\hline January 9, 2007 & 1030 & 22 & 70 & 30 \\
\hline March 14, 2007 & 1020 & 15 & 67 & 23 \\
\hline March 22, 2007 & 1000 & 39 & 98 & 74 \\
\hline March 26, 2007 & 1040 & 190 & 295 & 316 \\
\hline March 31, 2007 & 1230 & 220 & 1,370 & 459 \\
\hline April 16, 2007 & 1215 & 65 & 751 & 94 \\
\hline May 7, 2007 & 1030 & 170 & 3,725 & 211 \\
\hline June 29, 2007 & 1025 & 68 & 401 & 92 \\
\hline September 4, 2007 & 1126 & 15 & 28 & 22 \\
\hline April 24, 2008 & 1140 & 123 & 269 & 136 \\
\hline May 9, 2008 & 1135 & 253 & 3,103 & 283 \\
\hline June 19, 2008 & 0945 & 92 & 223 & 67 \\
\hline September 15, 2008 & 1055 & 74 & 404 & 146 \\
\hline October 16, 2008 & 1010 & 110 & 839 & 112 \\
\hline March 31, 2009 & 1120 & 220 & 721 & 364 \\
\hline April 27, 2009 & 1215 & 270 & 2,150 & 318 \\
\hline June 17, 2009 & 1040 & 140 & 349 & 201 \\
\hline August 20, 2009 & 1050 & 220 & 103 & 278 \\
\hline September 10, 2009 & 1130 & 280 & 482 & 258 \\
\hline
\end{tabular}

${ }^{1}$ Data point removed from final analysis because of atypically large heterogeneity in channel cross-sectional data during sample collection. 
Table 6. Suspended-sediment concentration simple linear regression model dataset for the North Fork Ninnescah River upstream from Cheney Reservoir (site 07144780), south-central Kansas, 1999 through 2009.

[hh, hours; mm, minutes]

\begin{tabular}{|c|c|c|c|c|}
\hline Date & Time, in hhmm & $\begin{array}{l}\text { Turbidity, in formazin } \\
\text { nephelometric units }\end{array}$ & $\begin{array}{l}\text { Streamflow, in cubic } \\
\text { feet per second }\end{array}$ & $\begin{array}{l}\text { Suspended-sediment } \\
\text { concentration, } \\
\text { in milligrams per liter }\end{array}$ \\
\hline May 13,1999 & 1025 & 15 & 98 & 67 \\
\hline May 24, 1999 & 1045 & 138 & 158 & 233 \\
\hline June 10, 1999 & 1200 & 32 & 86 & 28 \\
\hline June 25, 1999 & 1115 & 120 & 237 & 180 \\
\hline July 8, 1999 & 1400 & 90 & 76 & 62 \\
\hline July 29, 1999 & 0955 & 56 & 60 & 43 \\
\hline December 2, 1999 & 1035 & 18 & 62 & 22 \\
\hline April 27, 2000 & 1045 & 13 & 110 & 32 \\
\hline May 25, 2000 & 1020 & 27 & 60 & 44 \\
\hline June 21, 2000 & 1200 & 45 & 47 & 65 \\
\hline October 26, 2000 & 1050 & 320 & 2,663 & 2,100 \\
\hline June 6, 2001 & 1135 & 250 & 1,753 & 303 \\
\hline June 27, 2001 & 1155 & 48 & 77 & 94 \\
\hline September $19,2001^{1}$ & 1025 & 1,335 & 188 & 547 \\
\hline January 8, 2002 & 1120 & 50 & 81 & 93 \\
\hline May 13, 2002 & 1040 & 245 & 318 & 226 \\
\hline May 15, 2002 & 1100 & 66 & 130 & 91 \\
\hline June $12,2002^{1}$ & 1110 & 965 & 478 & 801 \\
\hline August 14, 2002 & 1135 & 435 & 347 & 468 \\
\hline March 18, 2003 & 1200 & 600 & 396 & 1,090 \\
\hline March 19, 2003 & 1220 & 580 & 2,245 & 2,150 \\
\hline April 21, 2003 & 1130 & 130 & 551 & 208 \\
\hline March 5, 2004 & 1210 & 475 & 1,968 & 2,690 \\
\hline May 14, 2004 & 1035 & 210 & 579 & 219 \\
\hline June 14, 2004 & 0945 & 120 & 238 & 187 \\
\hline March 24, 2005 & 1015 & 105 & 381 & 174 \\
\hline May 16, 2005 & 1140 & 115 & 524 & 295 \\
\hline June 10, 2005 & 1055 & 240 & 1,100 & 673 \\
\hline June 13, 2005 & 0925 & 125 & 3,150 & 747 \\
\hline August 29, 2005 & 0935 & 140 & 256 & 227 \\
\hline March 2, 2006 & 0950 & 14 & 92 & 51 \\
\hline March 22, 2006 & 1130 & 71 & 144 & 99 \\
\hline June 5, 2006 & 1015 & 48 & 39 & 52 \\
\hline July 31, 2006 & 1030 & 31 & 15 & 23 \\
\hline September 7, 2006 & 1050 & 25 & 39 & 46 \\
\hline September 21, 2006 & 1000 & 13 & 24 & 19 \\
\hline January 9, 2007 & 1030 & 22 & 70 & 82 \\
\hline March 14, 2007 & 1020 & 15 & 67 & 38 \\
\hline March 22, 2007 & 1000 & 39 & 98 & 72 \\
\hline March 26, 2007 & 1040 & 190 & 295 & 333 \\
\hline
\end{tabular}


Table 6. Suspended-sediment concentration simple linear regression model dataset for the North Fork Ninnescah River upstream from Cheney Reservoir (site 07144780), south-central Kansas, 1999 through 2009._Continued

[hh, hours; mm, minutes]

\begin{tabular}{lcccc}
\hline \multicolumn{1}{c}{ Date } & Time, in hhmm & $\begin{array}{c}\text { Turbidity, in formazin } \\
\text { nephelometric units }\end{array}$ & $\begin{array}{c}\text { Streamflow, in cubic } \\
\text { feet per second }\end{array}$ & $\begin{array}{c}\text { Suspended-sediment } \\
\text { concentration, } \\
\text { in milligrams per liter }\end{array}$ \\
\hline March 31, 2007 & 1230 & 220 & 1,370 & 1,240 \\
April 16, 2007 & 1215 & 65 & 751 & 288 \\
May 7, 2007 & 1030 & 170 & 3,725 & 1,390 \\
June 29, 2007 & 1025 & 68 & 401 & 149 \\
April 24, 2008 & 1140 & 123 & 269 & 208 \\
May 9, 2008 & 1135 & 253 & 3,103 & 1,110 \\
June 19, 2008 & 0945 & 92 & 223 & 139 \\
September 15, 2008 & 1055 & 74 & 404 & 229 \\
October 16, 2008 & 1010 & 110 & 839 & 1,060 \\
March 31, 2009 & 1120 & 220 & 721 & 859 \\
April 27, 2009 & 1215 & 270 & 2,150 & 967 \\
June 17, 2009 & 1040 & 140 & 349 & 858 \\
August 20, 2009 & 1050 & 220 & 103 & 292 \\
September 10, 2009 & 1130 & 280 & 482 & 420 \\
\hline
\end{tabular}

${ }^{1}$ Data point removed from final analysis because of atypically large heterogeneity in channel cross-sectional data during sample collection. 


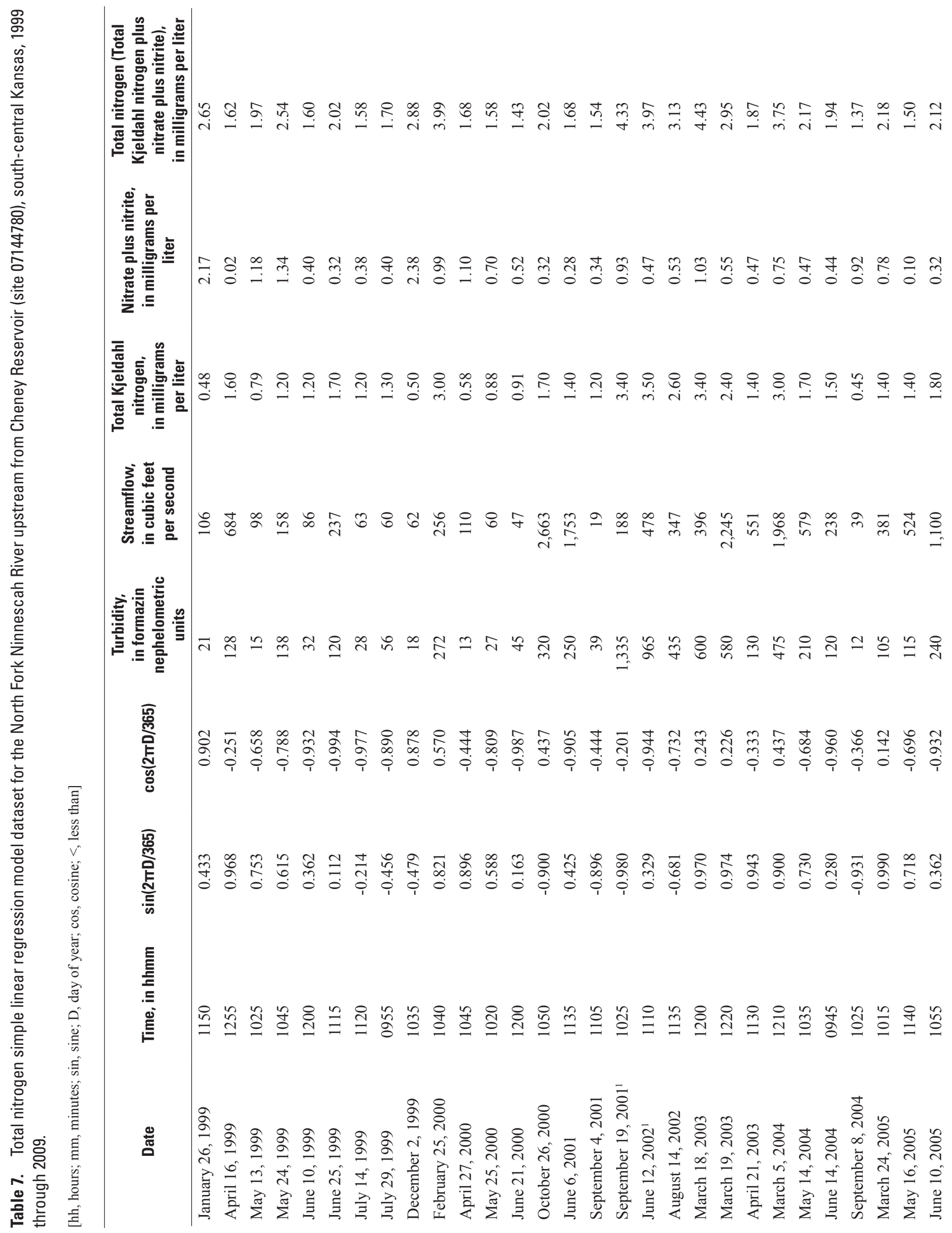




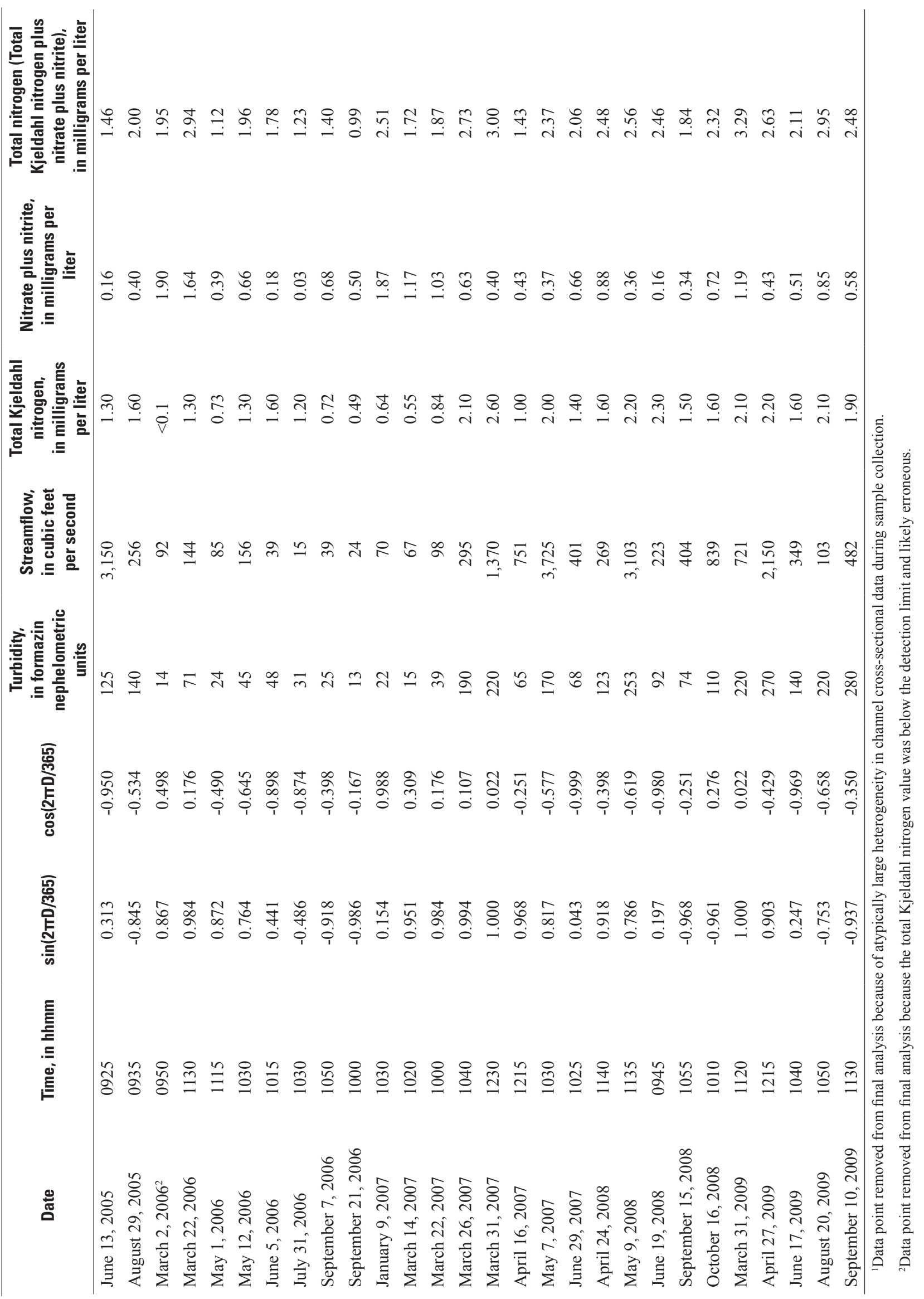


Table 8. Total Kjeldahl nitrogen simple linear regression model dataset for the North Fork Ninnescah River upstream from Cheney Reservoir (site 07144780), south-central Kansas, 1999 through 2009.

[hh, hours; mm, minutes; <, less than]

\begin{tabular}{|c|c|c|c|}
\hline Date & Time, in hhmm & $\begin{array}{l}\text { Turbidity, in formazin } \\
\text { nephelometric units }\end{array}$ & $\begin{array}{c}\text { Total Kjeldahl nitrogen, in } \\
\text { milligrams per liter }\end{array}$ \\
\hline January 26, 1999 & 1150 & 21 & 0.48 \\
\hline April 16, 1999 & 1255 & 128 & 1.60 \\
\hline May 13, 1999 & 1025 & 14.5 & 0.79 \\
\hline May 24, 1999 & 1045 & 138 & 1.20 \\
\hline June 10, 1999 & 1200 & 32 & 1.20 \\
\hline June 25, 1999 & 1115 & 120 & 1.70 \\
\hline July 29, 1999 & 0955 & 56 & 1.30 \\
\hline December 2, 1999 & 1035 & 18 & 0.50 \\
\hline February 25, 2000 & 1040 & 272 & 3.00 \\
\hline April 27, 2000 & 1045 & 13 & 0.58 \\
\hline May 25, 2000 & 1020 & 27 & 0.88 \\
\hline June 21, 2000 & 1200 & 45 & 0.91 \\
\hline October 26, 2000 & 1050 & 320 & 1.70 \\
\hline June 6, 2001 & 1135 & 250 & 1.40 \\
\hline September $19,2001^{1}$ & 1025 & 1,335 & 3.40 \\
\hline May 13, 2002 & 1040 & 245 & 2.00 \\
\hline June $12,2002^{1}$ & 1110 & 965 & 3.50 \\
\hline August 14, 2002 & 1135 & 435 & 2.60 \\
\hline March 18, 2003 & 1200 & 600 & 3.40 \\
\hline March 19, 2003 & 1220 & 580 & 2.40 \\
\hline April 21, 2003 & 1130 & 130 & 1.40 \\
\hline March 5, 2004 & 1210 & 475 & 3.00 \\
\hline May 14, 2004 & 1035 & 210 & 1.70 \\
\hline June 14, 2004 & 945 & 120 & 1.50 \\
\hline March 24, 2005 & 1015 & 105 & 1.40 \\
\hline May 16, 2005 & 1140 & 115 & 1.40 \\
\hline June 10, 2005 & 1055 & 240 & 1.80 \\
\hline June 13, 2005 & 0925 & 125 & 1.30 \\
\hline August 29, 2005 & 0935 & 140 & 1.60 \\
\hline March 2, $2006^{2}$ & 0950 & 14 & $<0.1$ \\
\hline March 22, 2006 & 1130 & 71 & 1.30 \\
\hline June 5, 2006 & 1015 & 48 & 1.60 \\
\hline July 31, 2006 & 1030 & 31 & 1.20 \\
\hline September 7, 2006 & 1050 & 25 & 0.72 \\
\hline September 21, 2006 & 1000 & 13 & 0.49 \\
\hline January 9, 2007 & 1030 & 22 & 0.64 \\
\hline March 14, 2007 & 1020 & 15 & 0.55 \\
\hline March 22, 2007 & 1000 & 39 & 0.84 \\
\hline March 26, 2007 & 1040 & 190 & 2.10 \\
\hline March 31, 2007 & 1230 & 220 & 2.60 \\
\hline April 16, 2007 & 1215 & 65 & 1.00 \\
\hline
\end{tabular}


Table 8. Total Kjeldahl nitrogen simple linear regression model dataset for the North Fork Ninnescah River upstream from Cheney Reservoir (site 07144780), south-central Kansas, 1999 through 2009._Continued

[hh, hours; mm, minutes; <, less than]

\begin{tabular}{lccc}
\hline \multicolumn{1}{c}{ Date } & Time, in hhmm & $\begin{array}{c}\text { Turbidity, in formazin } \\
\text { nephelometric units }\end{array}$ & $\begin{array}{c}\text { Total Kjeldahl nitrogen, in } \\
\text { milligrams per liter }\end{array}$ \\
\hline May 7, 2007 & 1030 & 170 & 2.00 \\
June 29, 2007 & 1025 & 68 & 1.40 \\
April 24, 2008 & 1140 & 123 & 1.60 \\
May 9, 2008 & 1135 & 253 & 2.20 \\
June 19, 2008 & 0945 & 92 & 2.30 \\
September 15, 2008 & 1055 & 74 & 1.50 \\
October 16, 2008 & 1010 & 110 & 1.60 \\
March 31, 2009 & 1120 & 220 & 2.10 \\
April 27, 2009 & 1215 & 270 & 2.20 \\
June 17, 2009 & 1040 & 140 & 1.60 \\
August 20, 2009 & 1050 & 220 & 2.10 \\
September 10, 2009 & 1130 & 280 & 1.90 \\
\hline
\end{tabular}

${ }^{1}$ Data point removed from final analysis because of atypically large heterogeneity in channel cross-sectional data during sample collection.

${ }^{2}$ Data point removed from final analysis because the total Kjeldahl nitrogen value was below the detection limit and likely erroneous. 
Table 9. Organic nitrogen simple linear regression model dataset for the North Fork Ninnescah River upstream from Cheney Reservoir (site 07144780), south-central Kansas, 1999 through 2009.

[hh, hours; mm, minutes; $<$, less than $]$

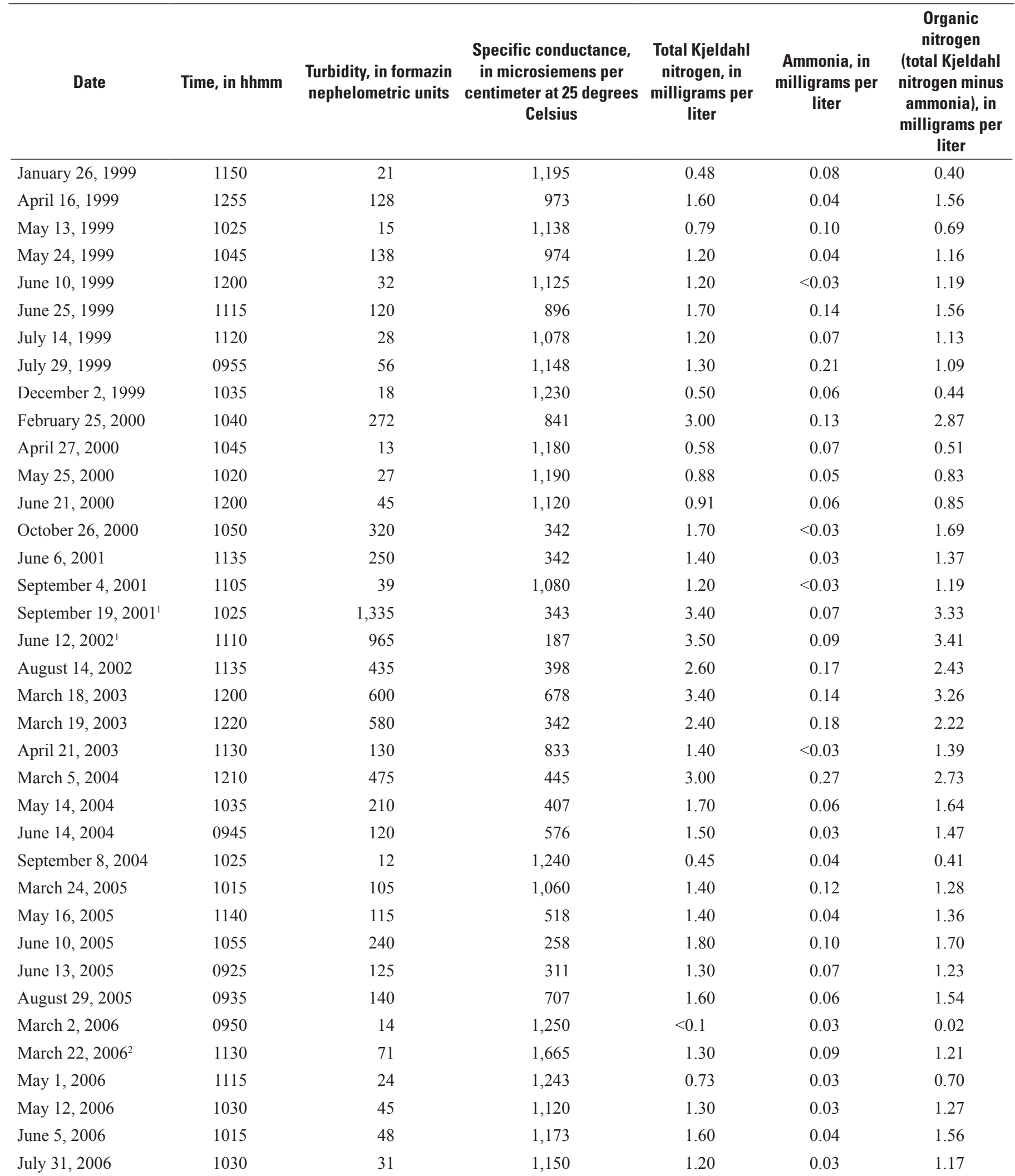


Table 9. Organic nitrogen simple linear regression model dataset for the North Fork Ninnescah River upstream from Cheney Reservoir (site 07144780), south-central Kansas, 1999 through 2009.-Continued

[hh, hours; mm, minutes; <, less than]

\begin{tabular}{|c|c|c|c|c|c|c|}
\hline Date & Time, in hhmm & $\begin{array}{l}\text { Turbidity, in formazin } \\
\text { nephelometric units }\end{array}$ & $\begin{array}{c}\text { Specific conductance, } \\
\text { in microsiemens per } \\
\text { centimeter at } 25 \text { degrees } \\
\text { Celsius }\end{array}$ & $\begin{array}{l}\text { Total Kjeldahl } \\
\text { nitrogen, in } \\
\text { milligrams per } \\
\text { liter }\end{array}$ & $\begin{array}{l}\text { Ammonia, in } \\
\text { milligrams per } \\
\text { liter }\end{array}$ & $\begin{array}{c}\text { Organic } \\
\text { nitrogen } \\
\text { (total Kjeldahl } \\
\text { nitrogen minus } \\
\text { ammonia), in } \\
\text { milligrams per } \\
\text { liter }\end{array}$ \\
\hline September 7, 2006 & 1050 & 25 & 1,280 & 0.72 & $<0.03$ & 0.71 \\
\hline September 21, 2006 & 1000 & 13 & 1,230 & 0.49 & 0.03 & 0.46 \\
\hline January 9, 2007 & 1030 & 22 & 1,430 & 0.64 & 0.04 & 0.60 \\
\hline March 14, 2007 & 1020 & 15 & 1,280 & 0.55 & 0.03 & 0.52 \\
\hline March 22, 2007 & 1000 & 39 & 1,120 & 0.84 & 0.07 & 0.77 \\
\hline March 26, 2007 & 1040 & 190 & 976 & 2.10 & 0.03 & 2.07 \\
\hline March 31, 2007 & 1230 & 220 & 637 & 2.60 & 0.10 & 2.50 \\
\hline April 16, 2007 & 1215 & 65 & 724 & 1.00 & 0.06 & 0.94 \\
\hline May 7, 2007 & 1030 & 170 & 317 & 2.00 & 0.05 & 1.95 \\
\hline June 29, 2007 & 1025 & 68 & 701 & 1.40 & 0.05 & 1.35 \\
\hline April 24, 2008 & 1140 & 123 & 569 & 1.60 & 0.08 & 1.52 \\
\hline May 9, 2008 & 1135 & 253 & 353 & 2.20 & 0.68 & 1.52 \\
\hline June 19, 2008 & 0945 & 92 & 978 & 2.30 & $<0.03$ & 2.29 \\
\hline September 15, 2008 & 1055 & 74 & 831 & 1.50 & 0.03 & 1.47 \\
\hline October 16, 2008 & 1010 & 110 & 589 & 1.60 & 0.10 & 1.50 \\
\hline March 31, 2009 & 1120 & 220 & 897 & 2.10 & 0.17 & 1.93 \\
\hline April 27, 2009 & 1215 & 270 & 478 & 2.20 & 0.10 & 2.10 \\
\hline June 17, 2009 & 1040 & 140 & 785 & 1.60 & $<0.03$ & 1.59 \\
\hline August 20, 2009 & 1050 & 220 & 1,095 & 2.10 & 0.02 & 2.07 \\
\hline September 10, 2009 & 1130 & 280 & 464 & 1.90 & 0.08 & 1.82 \\
\hline
\end{tabular}

${ }^{1}$ Data point removed from final analysis because of atypically large heterogeneity in channel cross-sectional data during sample collection.

${ }^{2}$ Data point removed from final analysis because of the large specific conductance value likely affected by road salt application. 
Table 10. Nitrate simple linear regression model dataset for the North Fork Ninnescah River upstream from Cheney Reservoir (site 07144780), south-central Kansas, 1999 through 2009.

[hh, hours; mm, minutes; sin, sine; D, day of year; cos, cosine]

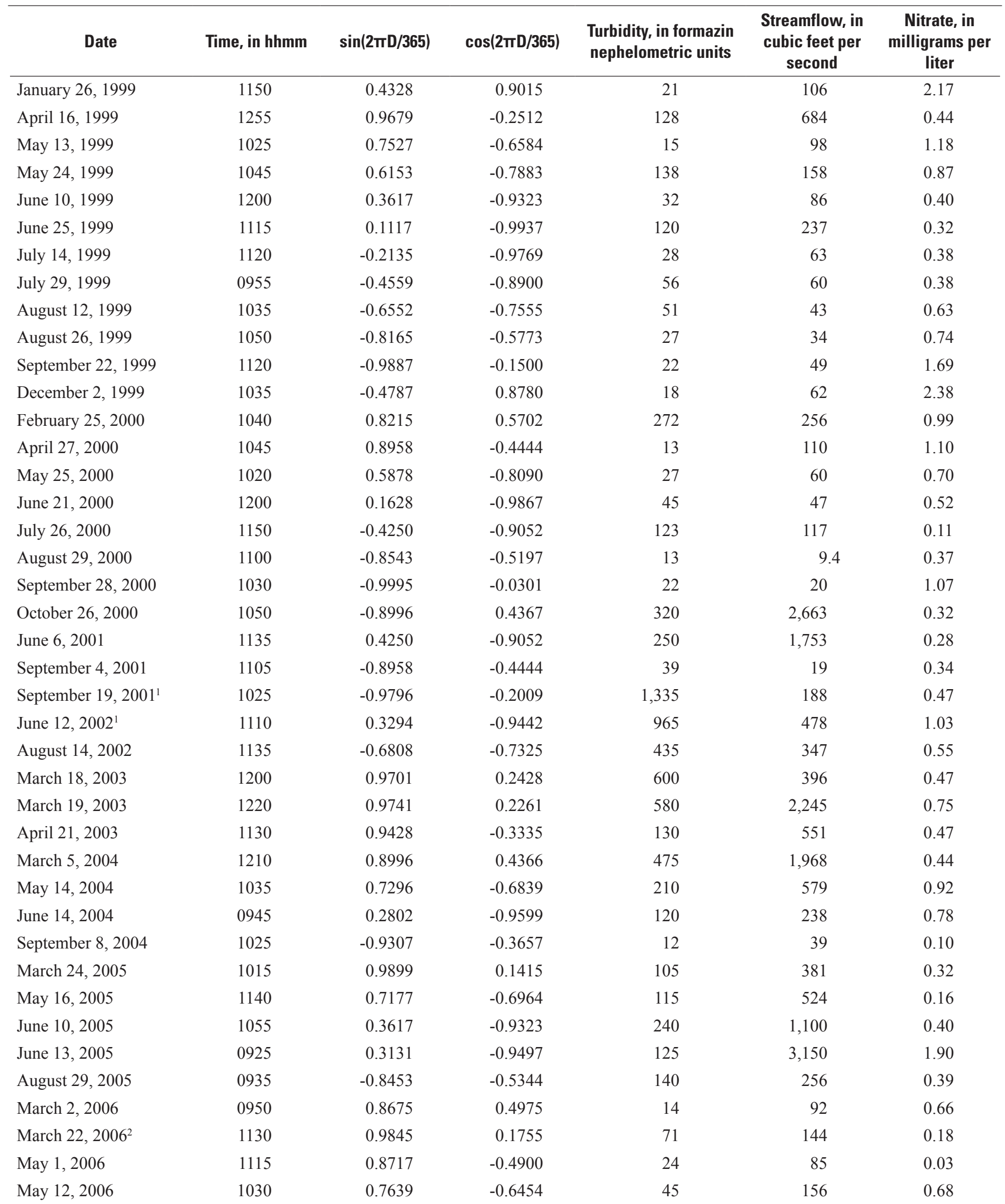


Table 10. Nitrate simple linear regression model dataset for the North Fork Ninnescah River upstream from Cheney Reservoir (site 07144780), south-central Kansas, 1999 through 2009.-Continued

[hh, hours; mm, minutes; sin, sine; D, day of year; cos, cosine]

\begin{tabular}{|c|c|c|c|c|c|c|}
\hline Date & Time, in hhmm & $\sin (2 \pi D / 365)$ & $\cos (2 \pi \mathrm{D} / 365)$ & $\begin{array}{l}\text { Turbidity, in formazin } \\
\text { nephelometric units }\end{array}$ & $\begin{array}{l}\text { Streamflow, in } \\
\text { cubic feet per } \\
\text { second }\end{array}$ & $\begin{array}{c}\text { Nitrate, in } \\
\text { milligrams per } \\
\text { liter }\end{array}$ \\
\hline June 5, 2006 & 1015 & 0.4405 & -0.8977 & 48 & 39 & 0.50 \\
\hline July 31, 2006 & 1030 & -0.4863 & -0.8738 & 31 & 15 & 1.87 \\
\hline September 7, 2006 & 1050 & -0.9176 & -0.3975 & 25 & 39 & 1.17 \\
\hline March 14, 2007 & 1020 & 0.9511 & 0.3090 & 15 & 67 & 0.40 \\
\hline March 22, 2007 & 1000 & 0.9845 & 0.1755 & 39 & 98 & 0.43 \\
\hline March 26, 2007 & 1040 & 0.9942 & 0.1074 & 190 & 295 & 0.37 \\
\hline March 31, 2007 & 1230 & 0.9998 & 0.0215 & 220 & 1,370 & 0.66 \\
\hline September 4, 2007 & 1126 & -0.8958 & -0.4444 & 15 & 28 & 0.14 \\
\hline April 24, 2008 & 1140 & 0.9176 & -0.3975 & 123 & 269 & 0.34 \\
\hline May 9, 2008 & 1135 & 0.7856 & -0.6187 & 253 & 3,103 & 0.70 \\
\hline June 19, 2008 & 0945 & 0.1967 & -0.9805 & 92 & 223 & 1.18 \\
\hline September 15, 2008 & 1055 & -0.9679 & -0.2512 & 74 & 404 & 0.42 \\
\hline October 16, 2008 & 1010 & -0.9611 & 0.2761 & 110 & 839 & 0.51 \\
\hline March 31, 2009 & 1120 & 0.9998 & 0.0215 & 220 & 721 & 0.83 \\
\hline April 27, 2009 & 1215 & 0.9034 & -0.4289 & 270 & 2,150 & 0.56 \\
\hline June 17, 2009 & 1040 & 0.2470 & -0.9690 & 140 & 349 & 0.51 \\
\hline
\end{tabular}

${ }^{1}$ Data point removed from final analysis because of atypically large heterogeneity in channel cross-sectional data during sample collection.

${ }^{2}$ Data point removed from final analysis because of the large specific conductance value likely affected by road salt application. 
Table 11. Total phosphorus simple linear regression model dataset for the North Fork Ninnescah River upstream from Cheney Reservoir (site 07144780), south-central Kansas, 1999 through 2009.

[hh, hours; mm, minutes]

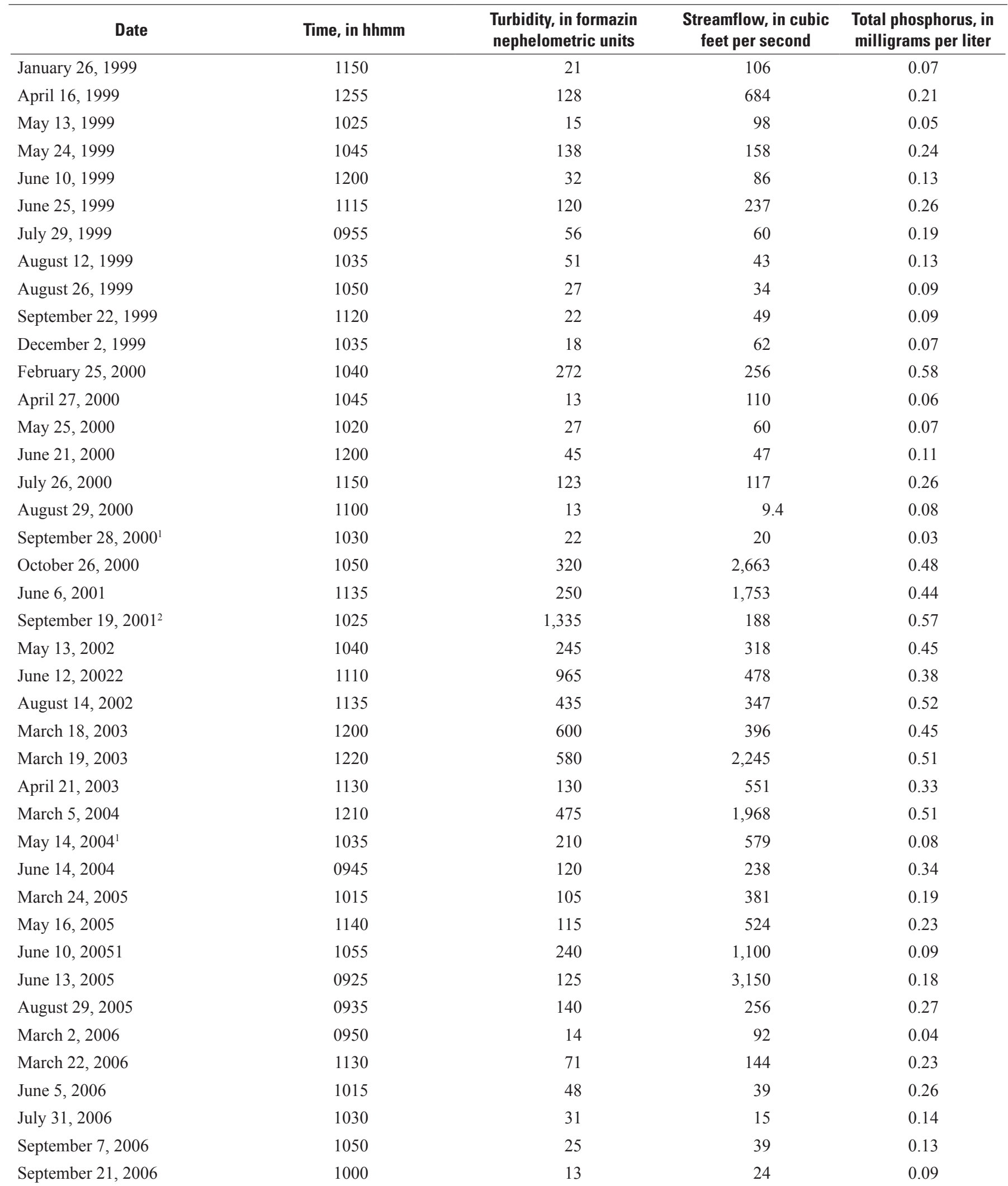


Table 11. Total phosphorus simple linear regression model dataset for the North Fork Ninnescah River upstream from Cheney Reservoir (site 07144780), south-central Kansas, 1999 through 2009.-Continued

[hh, hours; mm, minutes]

\begin{tabular}{lcccc}
\hline \multicolumn{1}{c}{ Date } & Time, in hhmm & $\begin{array}{c}\text { Turbidity, in formazin } \\
\text { nephelometric units }\end{array}$ & $\begin{array}{c}\text { Streamflow, in cubic } \\
\text { feet per second }\end{array}$ & $\begin{array}{c}\text { Total phosphorus, in } \\
\text { milligrams per liter }\end{array}$ \\
\hline January 9, 2007 & 1030 & 22 & 70 & 0.07 \\
March 14, 2007 & 1020 & 15 & 67 & 0.10 \\
March 22, 2007 & 1000 & 39 & 98 & 0.12 \\
March 26, 2007 & 1040 & 190 & 295 & 0.49 \\
March 31, 2007 & 1230 & 220 & 1,370 & 0.48 \\
April 16, 2007 & 1215 & 65 & 751 & 0.31 \\
May 7, 2007 & 1030 & 170 & 3,725 & 0.51 \\
June 29, 2007 & 1025 & 68 & 401 & 0.45 \\
September 4, 2007 & 1126 & 15 & 28 & 0.11 \\
April 24, 2008 & 1140 & 253 & 269 & 0.34 \\
May 9, 2008 & 1135 & 92 & 3,103 & 0.47 \\
June 19, 2008 & 0945 & 74 & 223 & 0.31 \\
September 15, 2008 & 1055 & 110 & 404 & 0.41 \\
October 16, 2008 & 1010 & 220 & 839 & 0.45 \\
March 31, 2009 & 1120 & 270 & 721 & 0.39 \\
April 27, 2009 & 1215 & 140 & 2,150 & 0.42 \\
June 17, 2009 & 1040 & 220 & 349 & 0.38 \\
August 20, 2009 & 1050 & 280 & 103 & 0.31 \\
September 10, 2009 & 1130 & 482 & 0.40 \\
\hline
\end{tabular}

'Data point removed from final analysis because of laboratory issues with phosphorus analysis. Dissolved phosphorus was greater than total phosphorus.

${ }^{2}$ Data point removed from final analysis because of atypically large heterogeneity in channel cross-sectional data during sample collection. 
Table 12. Orthophosphate simple linear regression model dataset for the North Fork Ninnescah River upstream from Cheney Reservoir (site 07144780), south-central Kansas, 1999 through 2009.

[hh, hours; mm, minutes]

\begin{tabular}{|c|c|c|c|}
\hline Date & Time, in hhmm & $\begin{array}{l}\text { Specific conductance, } \\
\text { in microsiemens per centime- } \\
\text { ter at } 25 \text { degrees Celsius }\end{array}$ & $\begin{array}{l}\text { Orthophosphate, in } \\
\text { milligrams per liter }\end{array}$ \\
\hline January 26, 1999 & 1150 & 1,195 & 0.02 \\
\hline April 16, 1999 & 1255 & 973 & 0.05 \\
\hline May 13, 1999 & 1025 & 1,138 & $<0.01$ \\
\hline May 24, 1999 & 1045 & 974 & 0.02 \\
\hline June 10, 1999 & 1200 & 1,125 & $<0.01$ \\
\hline June 25, 1999 & 1115 & 896 & 0.06 \\
\hline July 14, 1999 & 1120 & 1,078 & 0.02 \\
\hline July 29, 1999 & 0955 & 1,148 & 0.02 \\
\hline August 12, 1999 & 1035 & 1,150 & $<0.01$ \\
\hline August 26, 1999 & 1050 & 1,080 & $<0.01$ \\
\hline December 2, 1999 & 1035 & 1,230 & $<0.01$ \\
\hline February 25, 2000 & 1040 & 841 & $<0.01$ \\
\hline April 27, 2000 & 1045 & 1,180 & 0.01 \\
\hline May 25, 2000 & 1020 & 1,190 & $<0.01$ \\
\hline June 21, 2000 & 1200 & 1,120 & $<0.01$ \\
\hline July 26, 2000 & 1150 & 896 & $<0.01$ \\
\hline August 29, 2000 & 1100 & 1,080 & $<0.01$ \\
\hline September $28,2000^{1}$ & 1030 & 1,058 & $<0.01$ \\
\hline October 26, 2000 & 1050 & 342 & 0.18 \\
\hline June 6, 2001 & 1135 & 342 & 0.18 \\
\hline September 4, 2001 & 1105 & 1,080 & $<0.01$ \\
\hline September $19,2001^{2}$ & 1025 & 343 & 0.04 \\
\hline June $12,2002^{2}$ & 1110 & 187 & 0.19 \\
\hline August 14, 2002 & 1135 & 398 & 0.11 \\
\hline March 18, 2003 & 1200 & 678 & 0.05 \\
\hline March 19, 2003 & 1220 & 342 & 0.14 \\
\hline April 21, 2003 & 1130 & 833 & 0.07 \\
\hline March 5, 2004 & 1210 & 445 & 0.15 \\
\hline May $14,2004^{1}$ & 1035 & 407 & 0.16 \\
\hline June $14,2004^{3}$ & 0945 & 576 & 0.12 \\
\hline September 8, 2004 & 1025 & 1,240 & 0.02 \\
\hline March 24, 2005 & 1015 & 1,060 & 0.05 \\
\hline May 16, 2005 & 1140 & 518 & 0.04 \\
\hline June $10,2005^{3}$ & 1055 & 258 & 0.17 \\
\hline June 13, 20053 & 0925 & 311 & 0.16 \\
\hline August 29, 2005 & 0935 & 707 & 0.11 \\
\hline March 2, 2006 & 0950 & 1,250 & 0.02 \\
\hline March 22, 2006 & 1130 & 1,665 & 0.08 \\
\hline May 1, 2006 & 1115 & 1,243 & 0.02 \\
\hline May $12,2006^{3}$ & 1030 & 1,120 & 0.13 \\
\hline
\end{tabular}


Table 12. Orthophosphate simple linear regression model dataset for the North Fork Ninnescah River upstream from Cheney Reservoir (site 07144780), south-central Kansas, 1999 through 2009._Continued

[hh, hours; mm, minutes]

\begin{tabular}{lccc}
\hline \multicolumn{1}{c}{ Date } & Time, in hhmm & $\begin{array}{c}\text { Specific conductance, } \\
\text { in microsiemens per centime- } \\
\text { ter at 25 degrees Celsius }\end{array}$ & $\begin{array}{c}\text { Orthophosphate, in } \\
\text { milligrams per liter }\end{array}$ \\
\hline June 5, 2006 & 1015 & 1,173 & 0.02 \\
July 31, 2006 & 1030 & 1,150 & $<0.01$ \\
September 7, 2006 & 1050 & 1,280 & $<0.01$ \\
September 21, 2006 & 1000 & 1,230 & $<0.01$ \\
January 9, 2007 & 1030 & 1,430 & $<0.01$ \\
March 14, 2007 & 1020 & 1,280 & $<0.01$ \\
March 22, 2007 & 1000 & 1,120 & $<0.01$ \\
March 26, 2007 & 1040 & 976 & 0.03 \\
March 31, 2007 & 1230 & 637 & 0.14 \\
April 16, 2007 & 1215 & 724 & 0.11 \\
May 7, 2007 & 1030 & 317 & 0.21 \\
June 29, 2007 & 1025 & 701 & 0.23 \\
September 4, 2007 & 1126 & 1,140 & $<0.01$ \\
April 24, 2008 & 1140 & 569 & 0.14 \\
May 9, 2008 & 1135 & 353 & 0.16 \\
June 19, 2008 & 0945 & 978 & 0.04 \\
September 15, 2008 & 1055 & 831 & 0.09 \\
October 16, 2008 & 1010 & 589 & 0.19 \\
March 31, 2009 & 1120 & 897 & 0.09 \\
April 27, 2009 & 1215 & 478 & 0.13 \\
June 17, 2009 & 1040 & 785 & 0.12 \\
August 20, 2009 & 1050 & 1,095 & 0.04 \\
September 10, 2009 & 1130 & 464 & 0.11 \\
\hline
\end{tabular}

${ }^{1}$ Data point removed from final analysis because of laboratory issues with phosphorus analysis. Dissolved phosphorus was greater than total phosphorus.

${ }^{2}$ Data point removed from final analysis because of atypically large heterogeneity in channel cross-sectional data during sample collection.

${ }^{3}$ Data point removed from final analysis because of laboratory issues with phosphorus analysis. Orthophosphorus was larger than dissolved phosphorus.

${ }^{4}$ Data point removed from final analysis because of the large specific conductance value likely affected by road salt application. 
Table 13. Fecal coliform bacteria simple linear regression model dataset for the North Fork Ninnescah River upstream from Cheney Reservoir (site 07144780), south-central Kansas, 1999 through 2009.

[hh, hours; mm, minutes]

\begin{tabular}{|c|c|c|c|c|}
\hline Date & Time, in hhmm & $\begin{array}{l}\text { Turbidity, in formazin } \\
\text { nephelometric units }\end{array}$ & $\begin{array}{l}\text { Specific conductance, in } \\
\text { microsiemens per centimeter } \\
\text { at } 25 \text { degrees Celsius }\end{array}$ & $\begin{array}{l}\text { Fecal coliform bacteria, in } \\
\text { colonies per } 100 \text { milligrams }\end{array}$ \\
\hline January 26, 1999 & 1150 & 21 & 1,195 & 8.0 \\
\hline February 1, 1999 & 1055 & 120 & 1,060 & 200 \\
\hline April 15, 1999 & 1125 & 180 & 629 & 65,000 \\
\hline April 16, 1999 & 1255 & 128 & 973 & 5,700 \\
\hline May 24, 1999 & 1045 & 138 & 974 & 760 \\
\hline June 10, 1999 & 1200 & 32 & 1,125 & 280 \\
\hline June 25, 1999 & 1115 & 120 & 896 & 780 \\
\hline July 29, 1999 & 0955 & 56 & 1,148 & 190 \\
\hline December 2, 1999 & 1035 & 18 & 1,230 & 80 \\
\hline February 25, 2000 & 1040 & 272 & 841 & 13,000 \\
\hline April 27, 2000 & 1045 & 13 & 1,180 & 240 \\
\hline May 25, 2000 & 1020 & 27 & 1,190 & 100 \\
\hline June 21, 2000 & 1200 & 45 & 1,120 & 300 \\
\hline July 26, 2000 & 1150 & 123 & 896 & 700 \\
\hline August 29, 2000 & 1100 & 13 & 1,080 & 530 \\
\hline September 28, 2000 & 1030 & 22 & 1,058 & 330 \\
\hline October 26, 2000 & 1050 & 320 & 342 & 36,000 \\
\hline April 21, 2003 & 1130 & 130 & 833 & 2,500 \\
\hline March 5, 2004 & 1210 & 475 & 445 & 3,900 \\
\hline May 14, 2004 & 1035 & 210 & 407 & 11,000 \\
\hline June 14, 2004 & 0945 & 120 & 576 & 1,700 \\
\hline March 24, 2005 & 1015 & 105 & 1,060 & 3,200 \\
\hline May 16, 2005 & 1140 & 115 & 518 & 1,300 \\
\hline June 10, 2005 & 1055 & 240 & 258 & 810 \\
\hline June 13, 2005 & 0925 & 125 & 311 & 3,300 \\
\hline August 29, 2005 & 0935 & 140 & 707 & 590 \\
\hline March 2, 2006 & 0950 & 14 & 1,250 & 27 \\
\hline $\operatorname{March} 22,2006^{2}$ & 1130 & 71 & 1,665 & 220 \\
\hline June 5, 2006 & 1015 & 48 & 1,173 & 19 \\
\hline July 31, 2006 & 1030 & 31 & 1,150 & 400 \\
\hline
\end{tabular}


Table 13. Fecal coliform bacteria simple linear regression model dataset for the North Fork Ninnescah River upstream from Cheney Reservoir (site 07144780), south-central Kansas, 1999 through 2009._Continued

[hh, hours; mm, minutes]

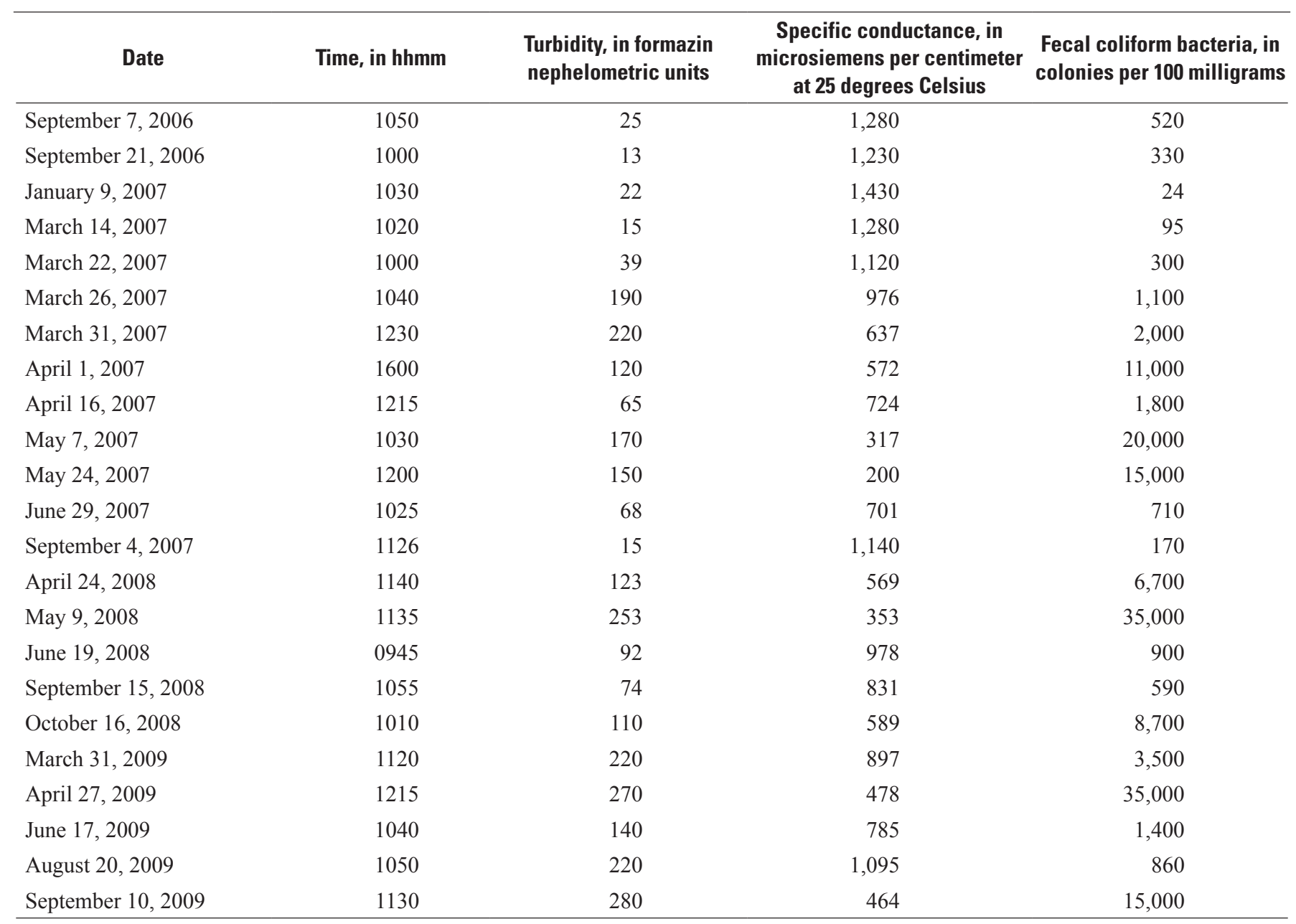

${ }^{1}$ Data point removed from final analysis because of atypically large heterogeneity in channel cross-sectional data during sample collection.

${ }^{2}$ Data point removed from final analysis because of the large specific conductance value likely affected by road salt application. 
Table 14. Escherichia coli bacteria simple linear regression model dataset for the North Fork Ninnescah River upstream from Cheney Reservoir (site 07144780), south-central Kansas, 1999 through 2009.

[hh, hours; mm, minutes]

\begin{tabular}{|c|c|c|c|c|c|}
\hline Date & $\begin{array}{l}\text { Time, } \\
\text { in hhmm }\end{array}$ & $\begin{array}{l}\text { Turbidity, in formazin } \\
\text { nephelometric units }\end{array}$ & $\begin{array}{l}\text { Specific conductance, } \\
\text { in microsiemens } \\
\text { per centimeter at } 25 \\
\text { degrees Celsius }\end{array}$ & $\begin{array}{l}\text { Streamflow, in cubic } \\
\text { feet per second }\end{array}$ & $\begin{array}{c}\text { Escherichia coli, } \\
\text { in colonies per } \\
100 \text { milliliters }\end{array}$ \\
\hline September 7, 2006 & 1050 & 25 & 1,280 & 39 & 250 \\
\hline September 21, 2006 & 1000 & 13 & 1,230 & 24 & 140 \\
\hline March 14, 2007 & 1020 & 15 & 1,280 & 67 & 82 \\
\hline March 26, 2007 & 1040 & 190 & 976 & 295 & 1,300 \\
\hline March 31, 2007 & 1230 & 220 & 637 & 1,370 & 6,000 \\
\hline April 1, 2007 & 1600 & 120 & 572 & 1,660 & 6,100 \\
\hline June 29, 2007 & 1025 & 68 & 701 & 401 & 680 \\
\hline April 24, 2008 & 1140 & 123 & 569 & 269 & 2,600 \\
\hline May 9, 2008 & 1135 & 253 & 353 & 3,103 & 28,000 \\
\hline June 19, 2008 & 0945 & 92 & 978 & 223 & 670 \\
\hline September 15, 2008 & 1055 & 74 & 831 & 404 & 620 \\
\hline October 16, 2008 & 1010 & 110 & 589 & 839 & 6,300 \\
\hline March 31, 2009 & 1120 & 220 & 897 & 721 & 3,900 \\
\hline April 27, 2009 & 1215 & 270 & 478 & 2,150 & 30,000 \\
\hline June 17, 2009 & 1040 & 140 & 785 & 349 & 1,200 \\
\hline
\end{tabular}


Table 15. Total organic carbon simple linear regression model dataset for the North Fork Ninnescah River upstream from Cheney Reservoir (site 07144780), south-central Kansas, 1999 through 2009.

[hh, hours; mm, minutes]

\begin{tabular}{|c|c|c|c|}
\hline Date & Time, in hhmm & $\begin{array}{l}\text { Turbidity, in formazin } \\
\text { nephelometric units }\end{array}$ & $\begin{array}{l}\text { Total organic carbon, } \\
\text { in milligrams per liter }\end{array}$ \\
\hline April 16, 1999 & 1255 & 128 & 10.7 \\
\hline June 10, 1999 & 1200 & 32 & 3.40 \\
\hline June 25, 1999 & 1115 & 120 & 7.60 \\
\hline July 29, 1999 & 0955 & 56 & 4.60 \\
\hline September 22, 1999 & 1120 & 22 & 3.00 \\
\hline December 2, 1999 & 1035 & 18 & 2.50 \\
\hline February 25, 2000 & 1040 & 272 & 9.70 \\
\hline October 26, 2000 & 1050 & 320 & 6.70 \\
\hline June 6, 2001 & 1135 & 250 & 7.40 \\
\hline September $19,2001^{1}$ & 1025 & 1,335 & 6.30 \\
\hline June $12,2002^{1}$ & 1110 & 965 & 22.5 \\
\hline August 14, 2002 & 1135 & 435 & 19.4 \\
\hline March 18, 2003 & 1200 & 600 & 15.9 \\
\hline March 19, 2003 & 1220 & 580 & 18.9 \\
\hline April 21, 2003 & 1130 & 130 & 13.7 \\
\hline March 5, 2004 & 1210 & 475 & 20.5 \\
\hline May 14, 2004 & 1035 & 210 & 12.9 \\
\hline June 14, 2004 & 0945 & 120 & 12.6 \\
\hline March 24, 2005 & 1015 & 105 & 9.90 \\
\hline May 16, 2005 & 1140 & 115 & 9.50 \\
\hline June 10,2005 & 1055 & 240 & 15.4 \\
\hline June 13, 2005 & 0925 & 125 & 15.6 \\
\hline August 29, 2005 & 0935 & 140 & 12.6 \\
\hline March 2, 2006 & 0950 & 14 & 2.80 \\
\hline March 22, 2006 & 1130 & 71 & 9.00 \\
\hline June 5, 2006 & 1015 & 48 & 6.90 \\
\hline July 31, 2006 & 1030 & 31 & 5.70 \\
\hline September 7, 2006 & 1050 & 25 & 4.90 \\
\hline September 21, 2006 & 1000 & 13 & 4.20 \\
\hline January 9, 2007 & 1030 & 22 & 4.50 \\
\hline March 22, 2007 & 1000 & 39 & 5.50 \\
\hline March 26, 2007 & 1040 & 190 & 15.7 \\
\hline March 31, 2007 & 1230 & 220 & 18.7 \\
\hline April 16, 2007 & 1215 & 65 & 10.5 \\
\hline May 7, 2007 & 1030 & 170 & 16.4 \\
\hline June 29, 2007 & 1025 & 68 & 12.7 \\
\hline September 4, 2007 & 1126 & 15 & 4.21 \\
\hline April 24, 2008 & 1140 & 123 & 13.0 \\
\hline May 9, 2008 & 1135 & 253 & 15.3 \\
\hline June 19, 2008 & 0945 & 92 & 11.2 \\
\hline September 15, 2008 & 1055 & 74 & 12.9 \\
\hline
\end{tabular}


Table 15. Total organic carbon simple linear regression model dataset for the North Fork Ninnescah River upstream from Cheney Reservoir (site 07144780), south-central Kansas, 1999 through 2009._-Continued

[hh, hours; mm, minutes]

\begin{tabular}{lccc}
\hline \multicolumn{1}{c}{ Date } & Time, in hhmm & $\begin{array}{c}\text { Turbidity, in formazin } \\
\text { nephelometric units }\end{array}$ & $\begin{array}{c}\text { Total organic carbon, } \\
\text { in milligrams per liter }\end{array}$ \\
\hline October 16, 2008 & 1010 & 110 & 13.5 \\
March 31, 2009 & 1120 & 220 & 17.4 \\
Apri1 27, 2009 & 1215 & 270 & 19.7 \\
June 17, 2009 & 1040 & 140 & 15.5 \\
August 20, 2009 & 1050 & 220 & 14.3 \\
September 10, 2009 & 1130 & 280 & 16.4 \\
\hline
\end{tabular}

${ }^{1}$ Data point removed from final analysis because of atypically large heterogeneity in channel cross-sectional data during sample collection. 


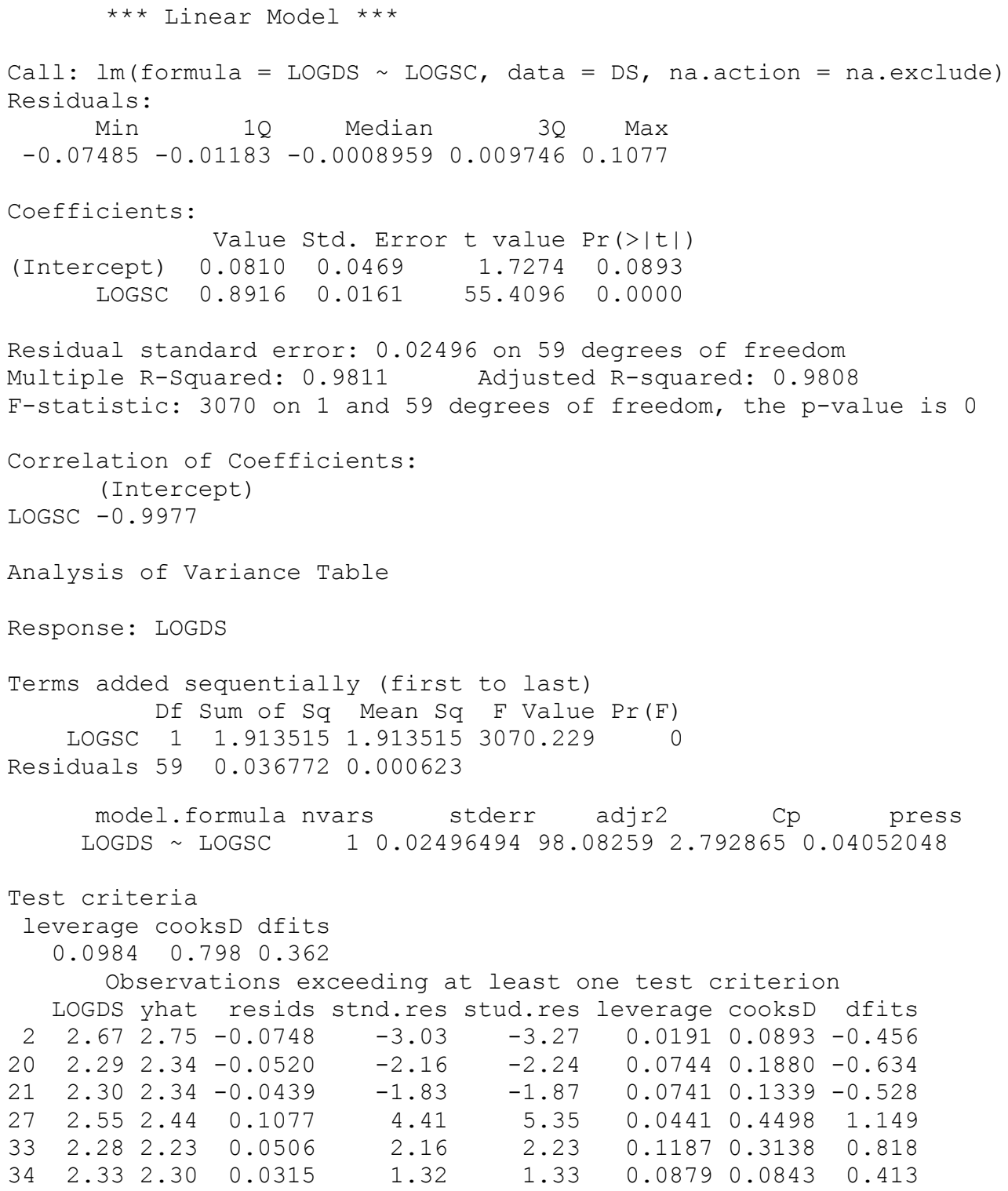

Figure 2. $\quad \mathrm{S}^{\circledR}$ output of regression model development using specific conductance (SC) as an explanatory variable for dissolved solids (DS) concentrations for the North Fork Ninnescah River upstream from Cheney Reservoir (site 07144780), south-central Kansas, 1999 through 2009. 

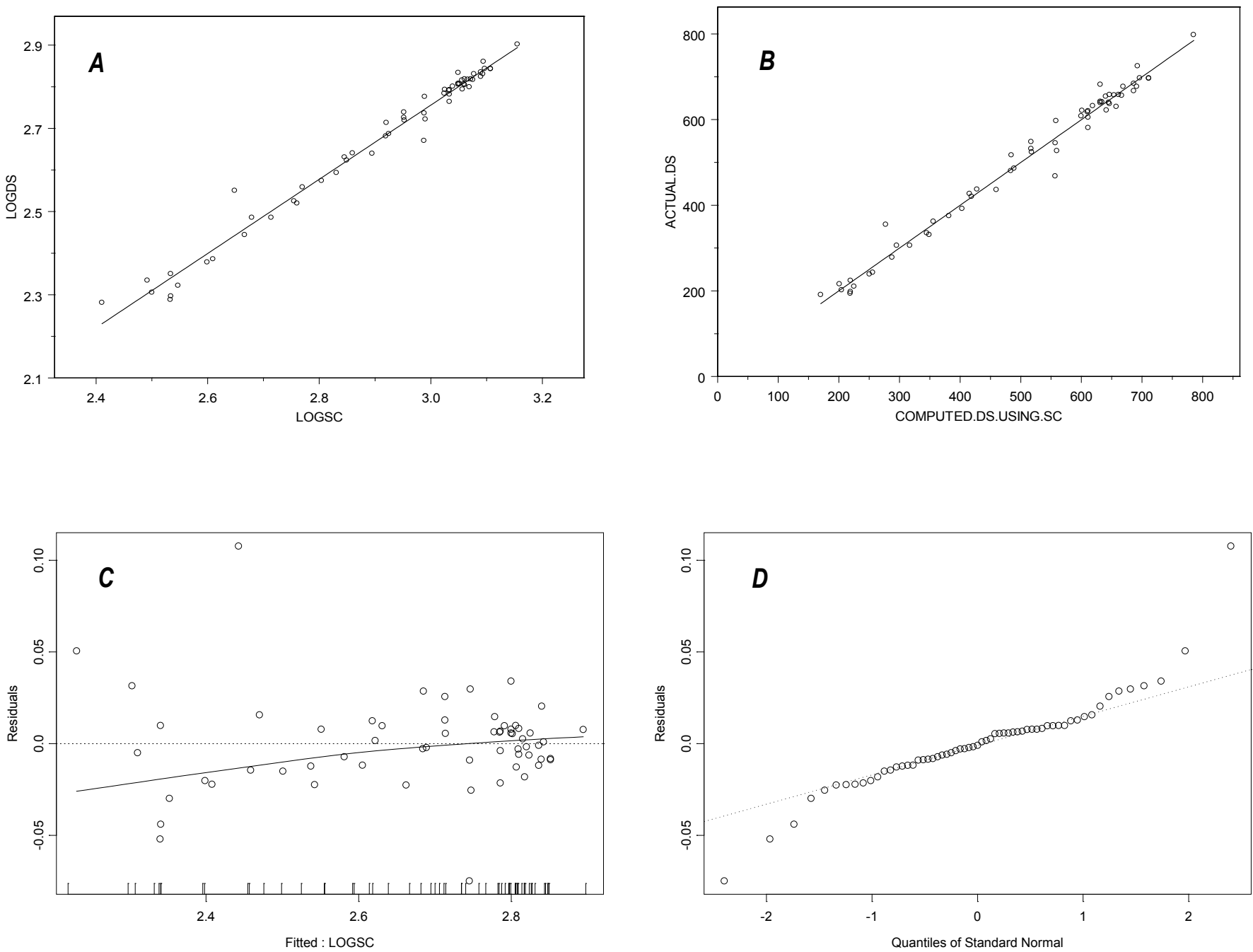

Figure 3. $S+{ }^{\circledR}$ output graphs from simple linear regression analysis showing $A$, log-transformed specific conductance (SC) versus log-transformed dissolved solids (DS) concentrations; $B$, computed versus actual DS concentrations; $C$, computed log-transformed DS concentrations versus regression residuals; and $D$, standard normal quantiles versus regression residuals for the North Fork Ninnescah River upstream from Cheney Reservoir (site 07144780), south-central Kansas, 1999 through 2009. 


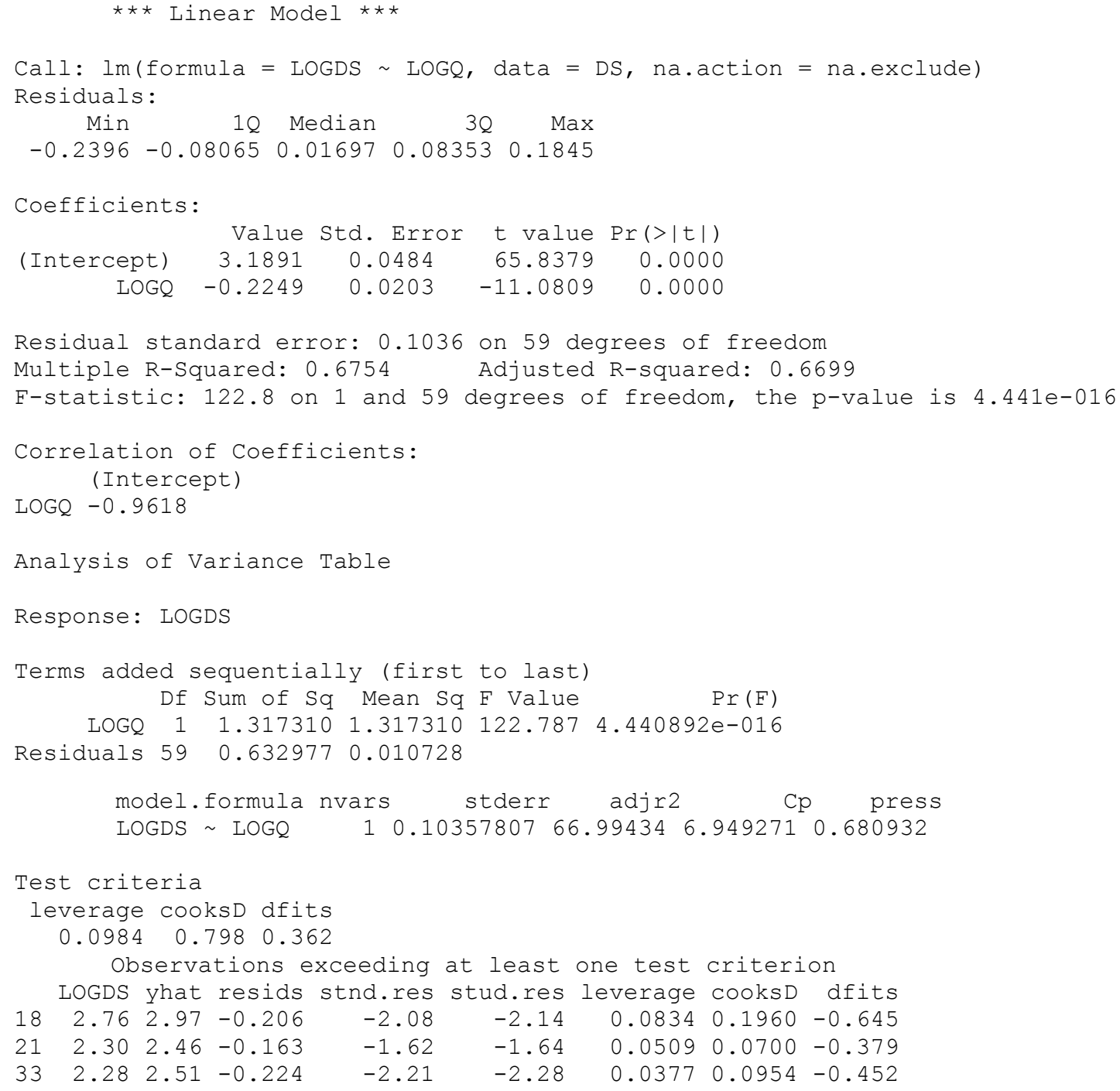

Figure 4. $S+{ }^{\oplus}$ output of regression model development using streamflow $(0)$ as an explanatory variable for dissolved solids (DS) concentrations for the North Fork Ninnescah River upstream from Cheney Reservoir (site 07144780), south-central Kansas, 1999 through 2009. 

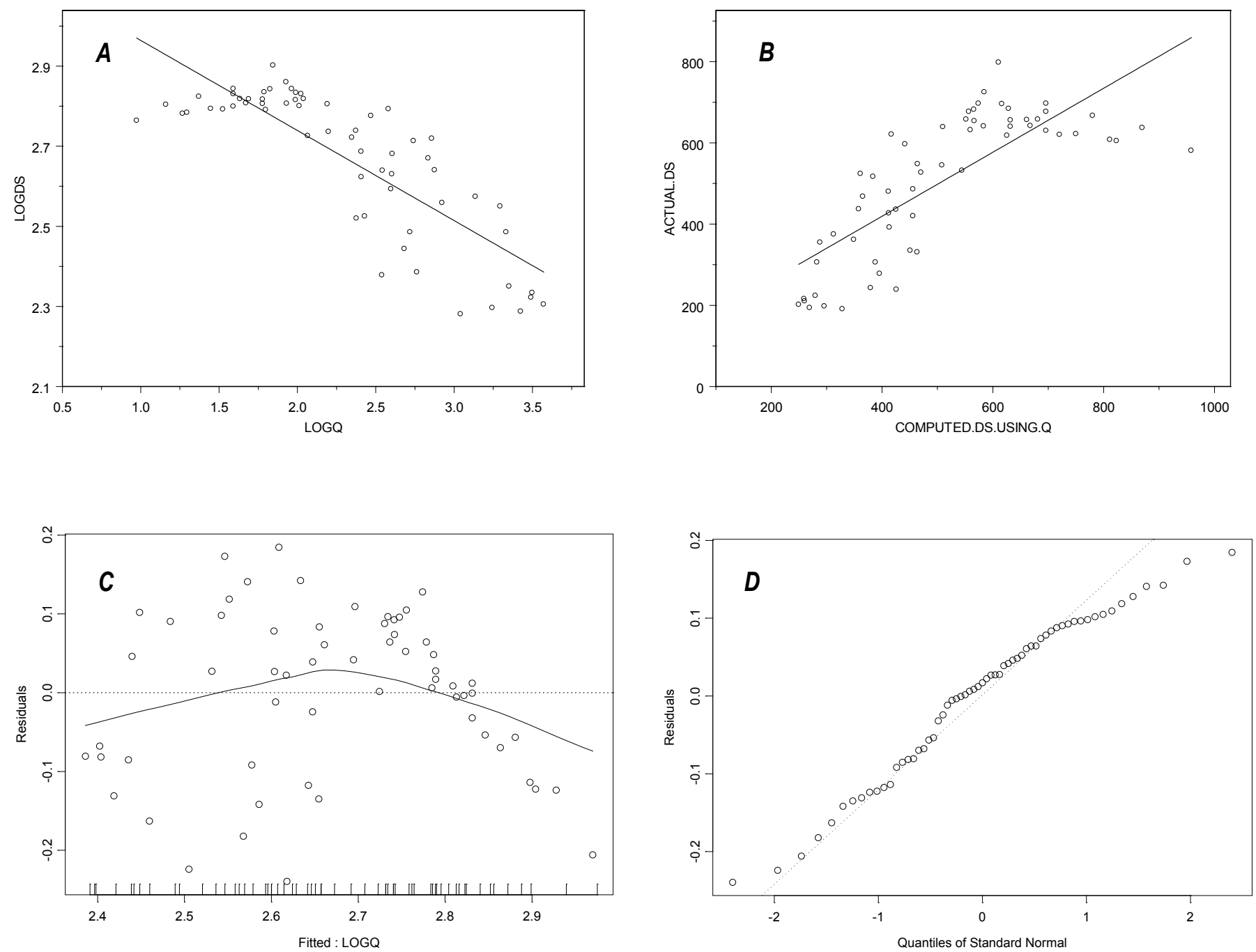

Figure 5. $S+{ }^{\circledR}$ output graphs from simple linear regression analysis showing $A$, log-transformed streamflow $(0)$ versus log-transformed dissolved solids (DS) concentrations; $B$, computed versus actual DS concentrations; $C$, computed log-transformed DS concentrations versus regression residuals; and $D$, standard normal quantiles versus regression residuals for the North Fork Ninnescah River upstream from Cheney Reservoir (site 07144780), south-central Kansas, 1999 through 2009. 


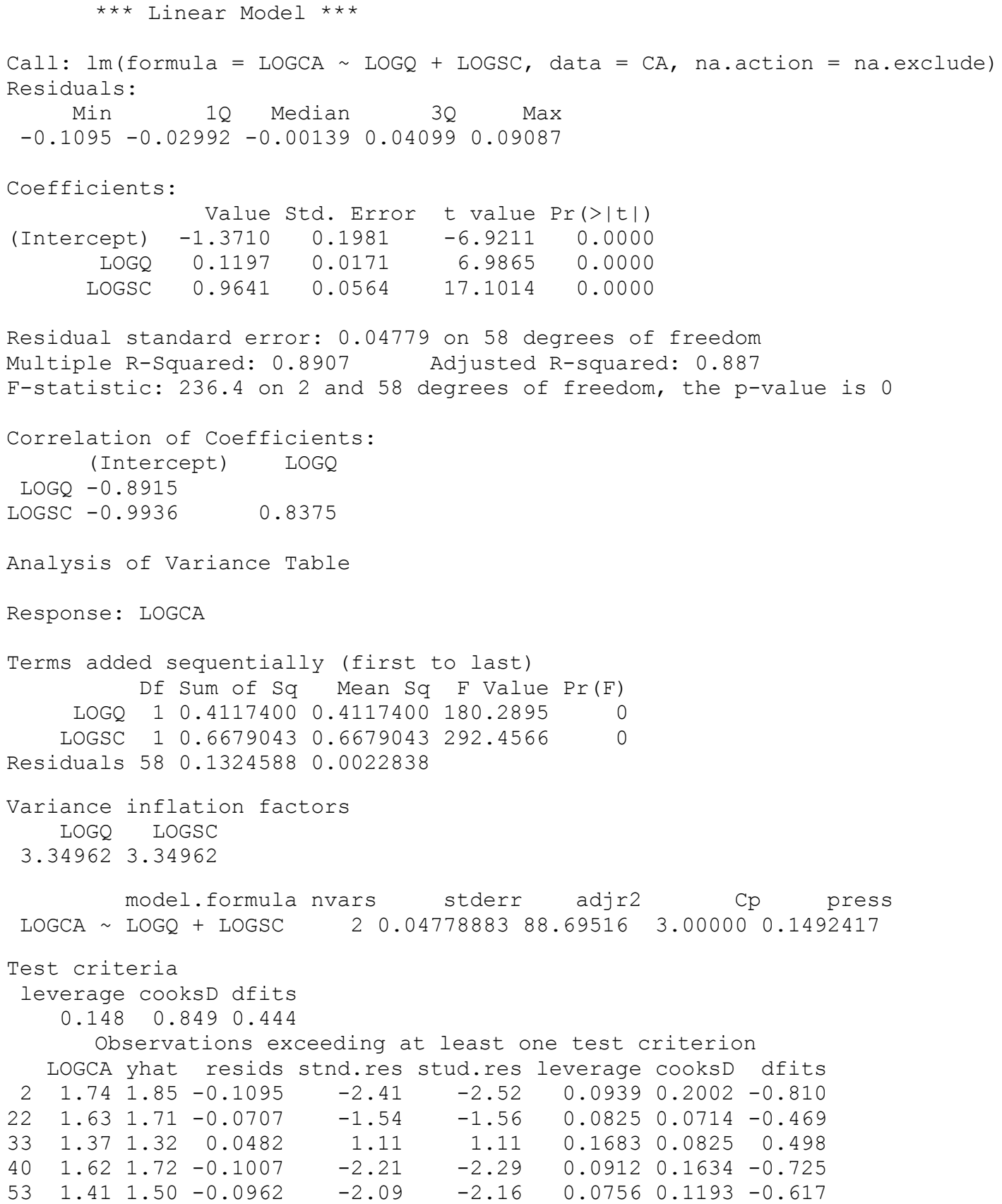

Figure 6. $\quad S+{ }^{\oplus}$ output of regression model development using streamflow ( 0 ) and specific conductance (SC) as explanatory variables for calcium (CA) concentrations for the North Fork Ninnescah River upstream from Cheney Reservoir (site 07144780), south-central Kansas, 1999 through 2009. 

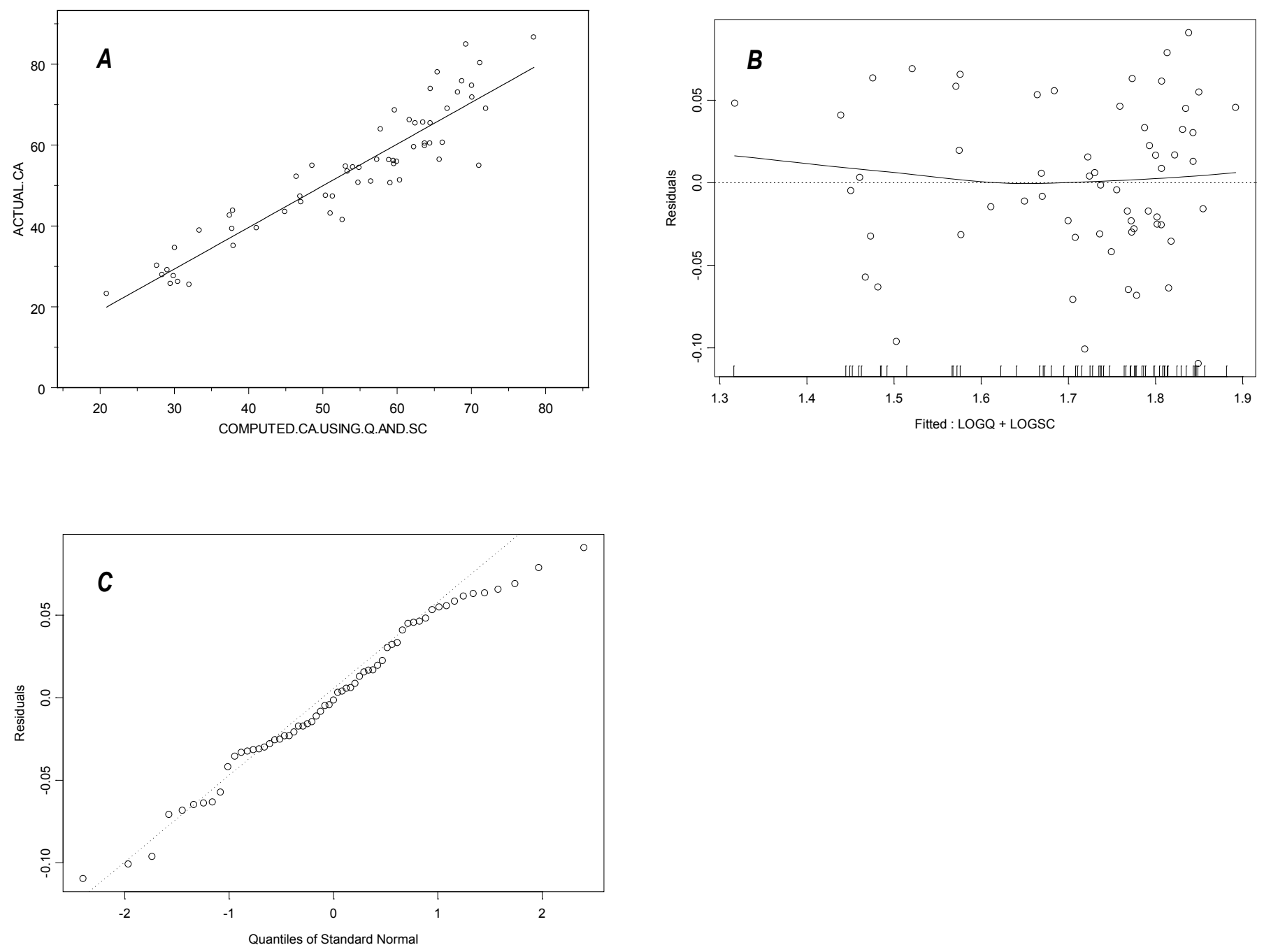

Figure 7. $\quad S+{ }^{\circledR}$ output graphs from simple linear regression analysis using streamflow $(0)$ and specific conductance (SC) as explanatory variables for calcium (CA) showing $A$, computed versus actual CA concentrations; $B$, computed log-transformed CA concentrations versus regression residuals; and $C$, standard normal quantiles versus regression residuals for the North Fork Ninnescah River upstream from Cheney Reservoir (site 07144780), south-central Kansas, 1999 through 2009. 


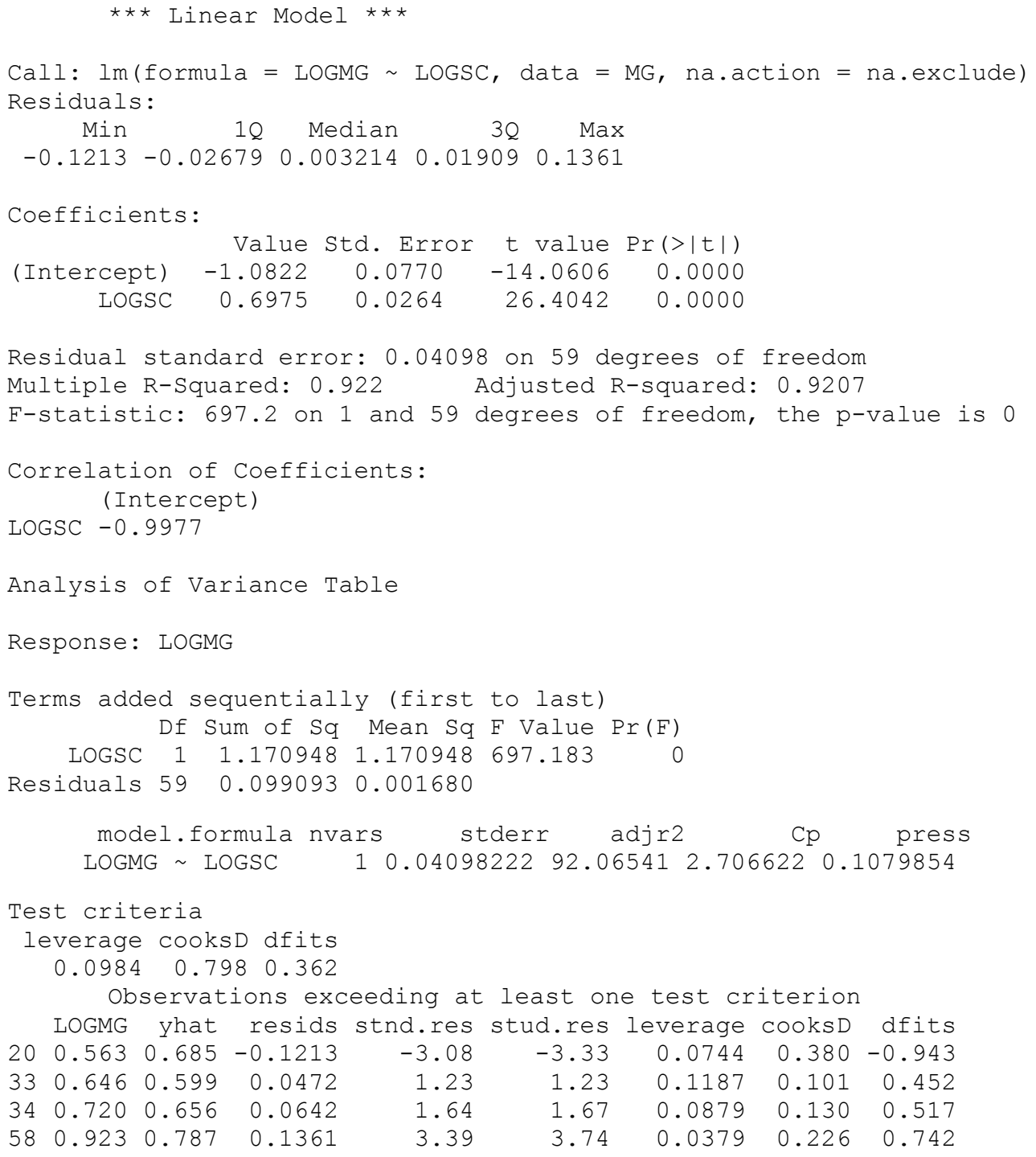

Figure 8. $\quad S+{ }^{\circledR}$ output of regression model development using specific conductance (SC) as an explanatory variable for magnesium (MG) concentrations for the North Fork Ninnescah River upstream from Cheney Reservoir (site 07144780), south-central Kansas, 1999 through 2009. 

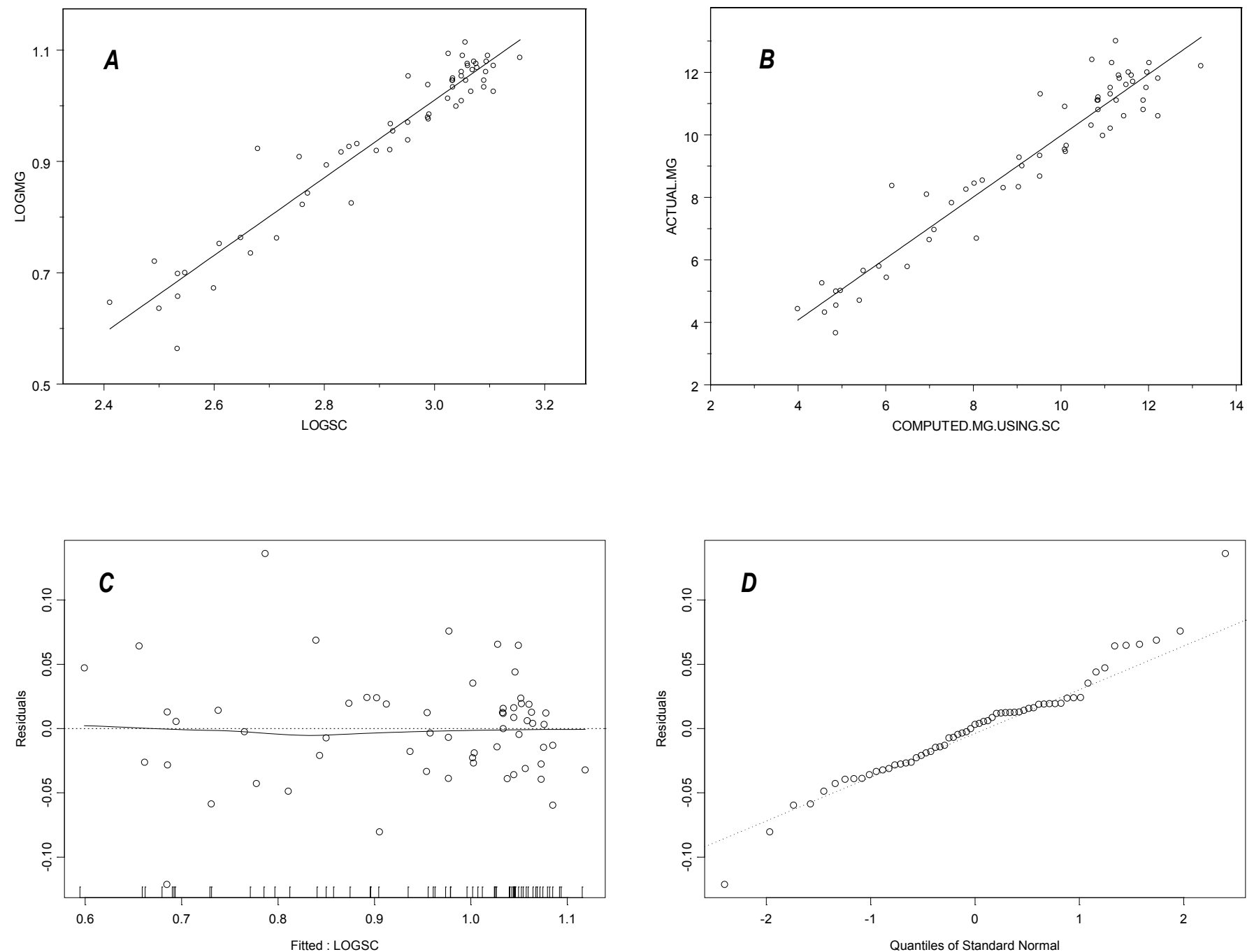

Figure 9. $S+{ }^{\circledR}$ output graphs from simple linear regression analysis showing $A$, log-transformed specific conductance (SC) versus log-transformed magnesium (MG) concentrations; $B$, computed versus actual $M G$ concentrations; $C$, computed log-transformed $M G$ concentrations versus regression residuals; and $D$, standard normal quantiles versus regression residuals for the North Fork Ninnescah River upstream from Cheney Reservoir (site 07144780), south-central Kansas, 1999 through 2009. 


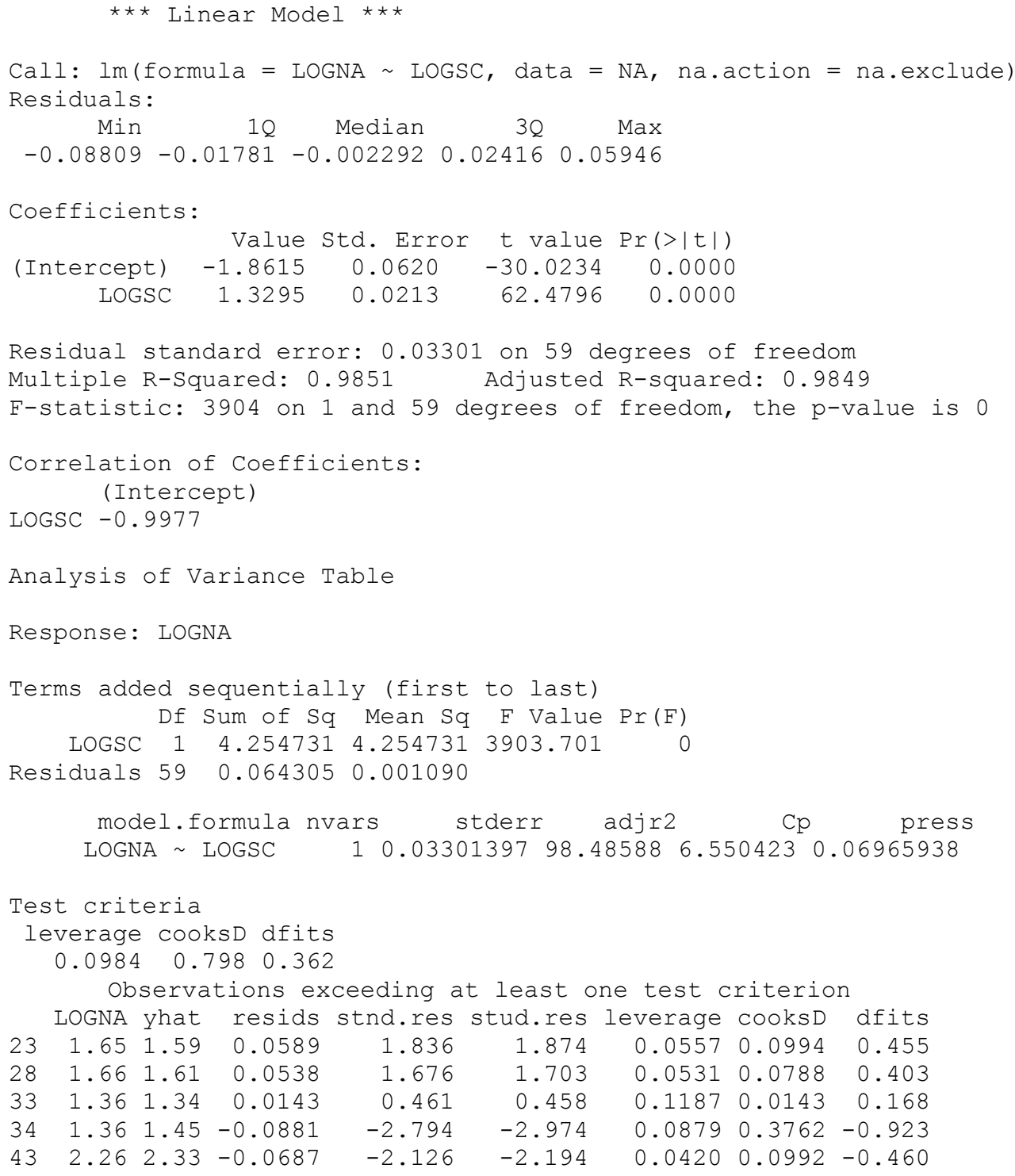

Figure 10. $\quad S+{ }^{\circledR}$ output of regression model development using specific conductance (SC) as an explanatory variable for sodium (NA) concentrations for the North Fork Ninnescah River upstream from Cheney Reservoir (site 07144780), south-central Kansas, 1999 through 2009. 

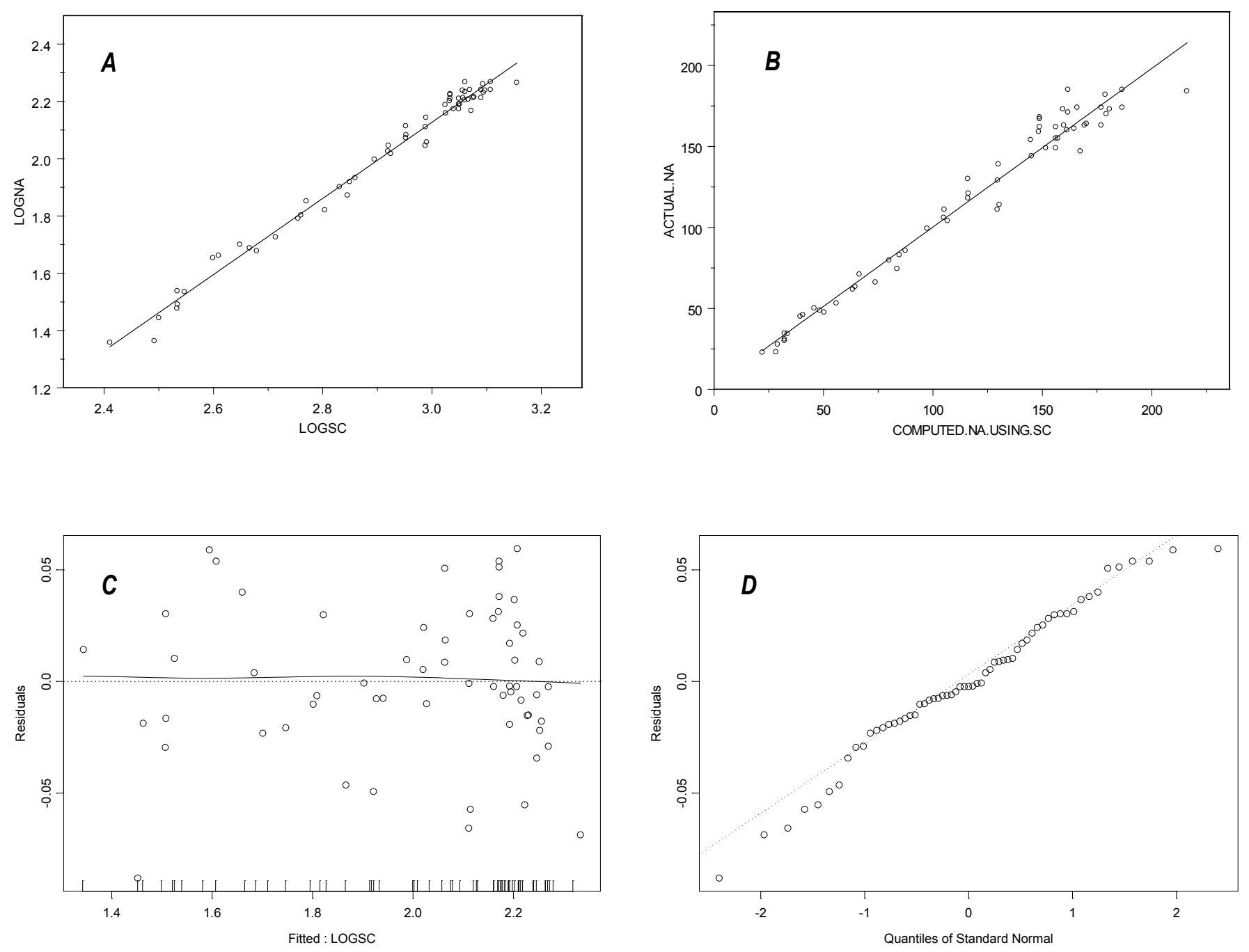

Figure 11. $S+{ }^{\circledR}$ output graphs of simple linear regression analysis showing $A$, log-transformed specific conductance (SC) versus log-transformed sodium (NA) concentrations; $B$, computed versus actual NA concentrations; $C$, computed log-transformed NA concentrations versus regression residuals; and $D$, standard normal quantiles versus regression residuals for the North Fork Ninnescah River upstream from Cheney Reservoir (site 07144780), south-central Kansas, 1999 through 2009. 


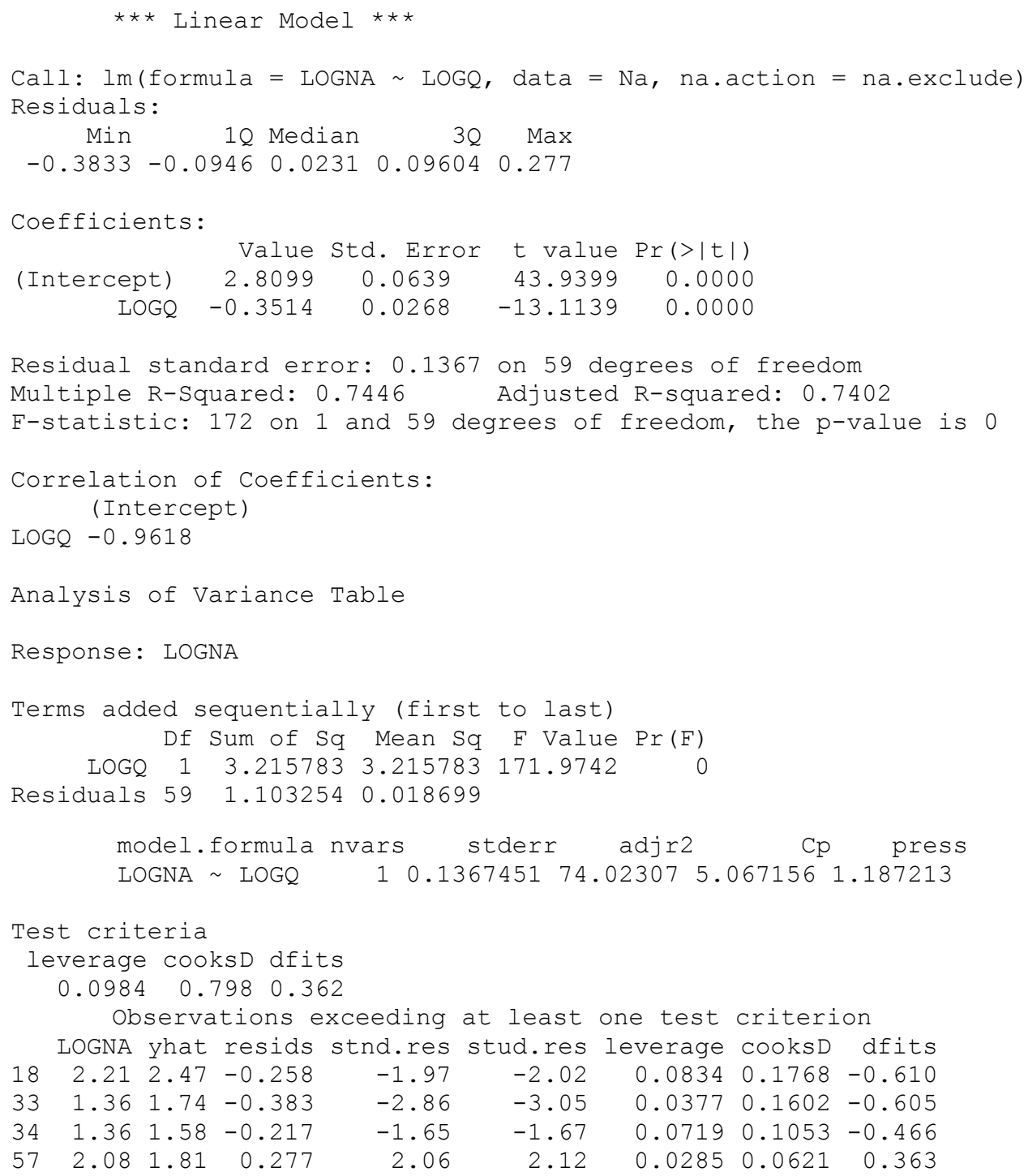

Figure 12. $S+{ }^{\circledR}$ output of regression model development using streamflow $(Q)$ as an explanatory variable for sodium (NA) concentrations for the North Fork Ninnescah River upstream from Cheney Reservoir (site 07144780), south-central Kansas, 1999 through 2009. 

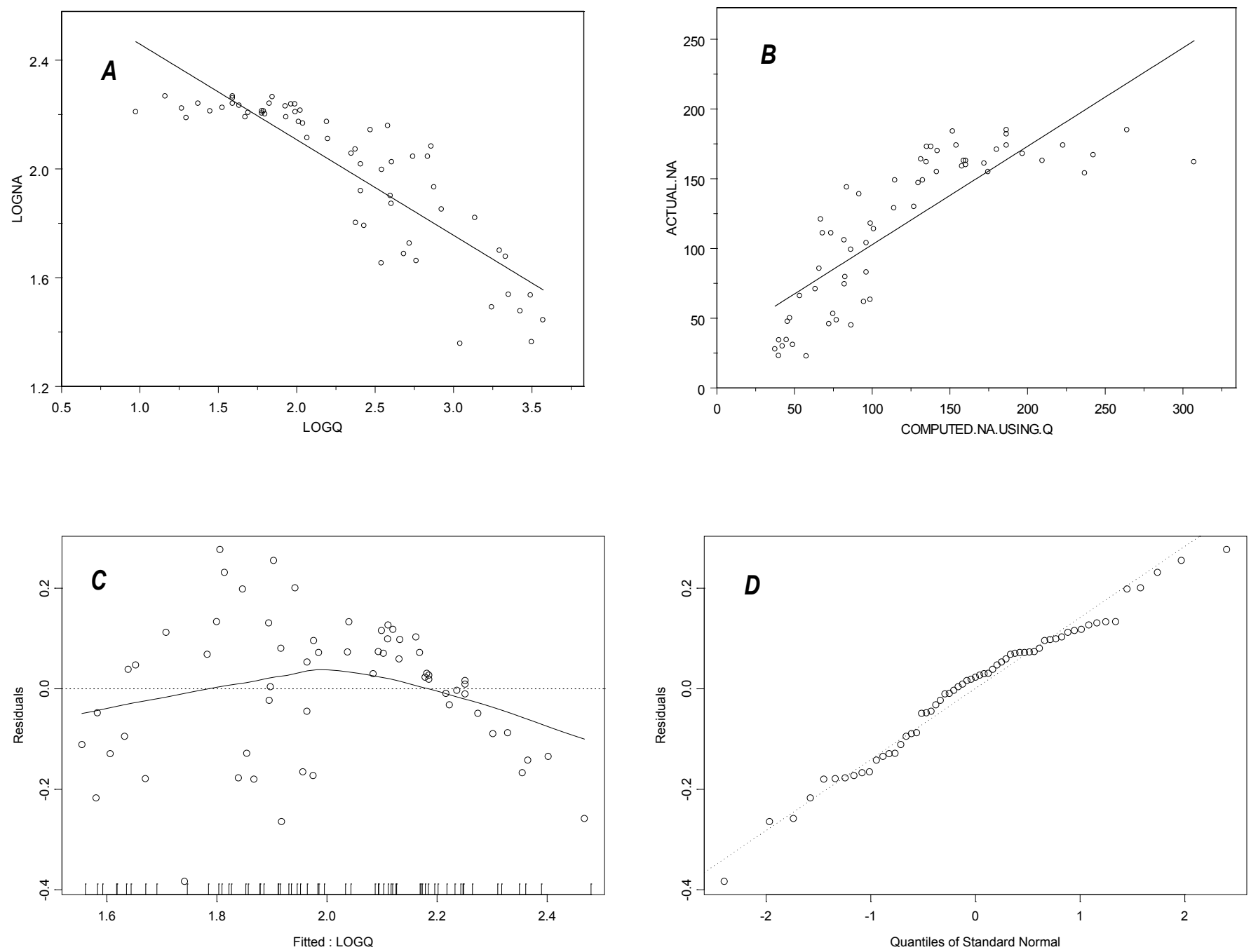

Figure 13. $S+{ }^{\circledR}$ output graphs from simple linear regression analysis showing $A$, log-transformed streamflow $(0)$ versus logtransformed sodium (NA) concentrations; $B$, computed versus actual NA concentrations; $C$, computed log-transformed NA concentrations versus regression residuals; and $D$, standard normal quantiles versus regression residuals for the North Fork Ninnescah River upstream from Cheney Reservoir (site 071447800), south-central Kansas, 1999 through 2009. 


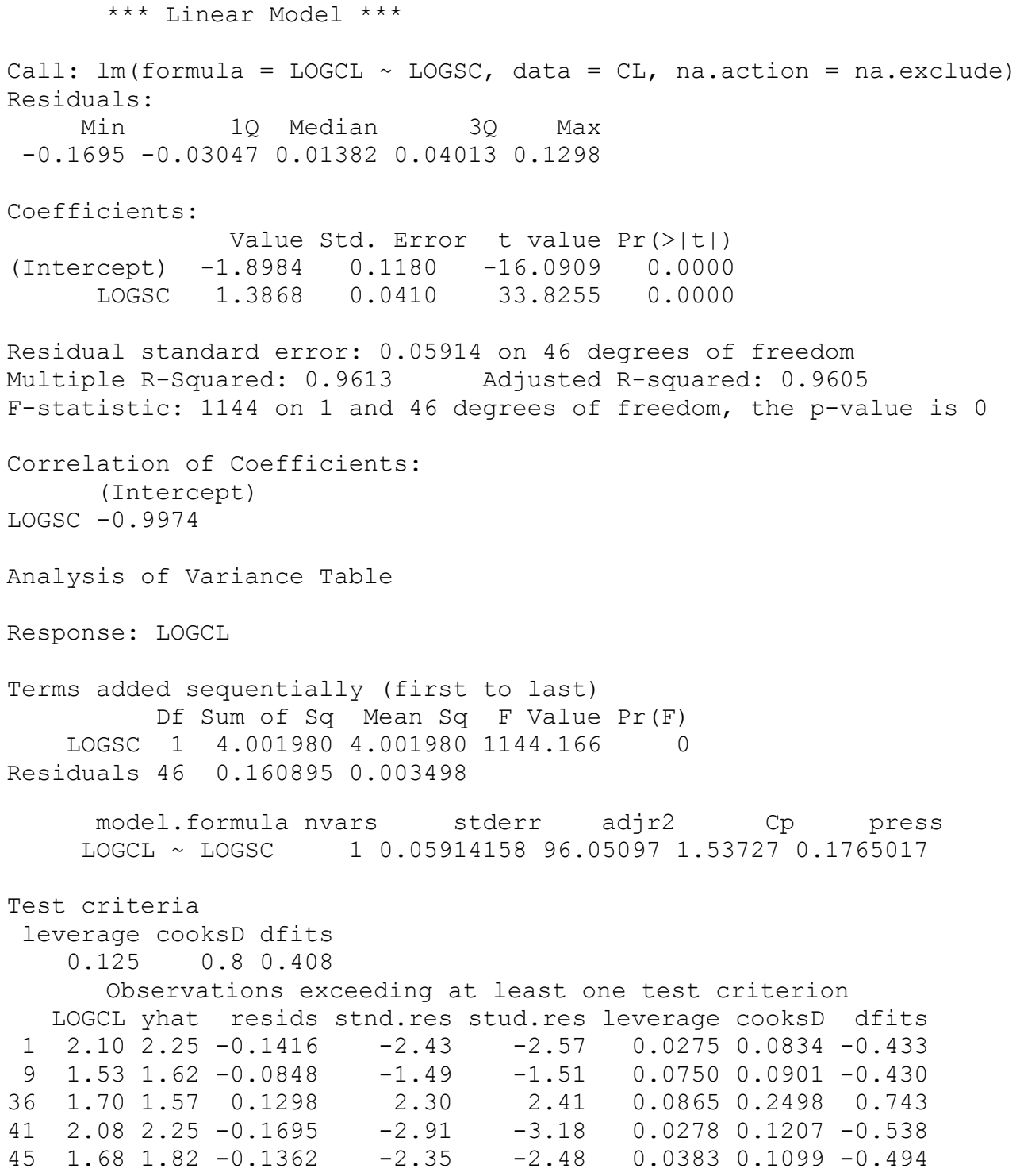

Figure 14. $S+{ }^{\circledR}$ output of regression model development using specific conductance (SC) as an explanatory variable for chloride (CL) concentrations for the North Fork Ninnescah River upstream from Cheney Reservoir (site 07144780), south-central Kansas, 1999 through 2009. 

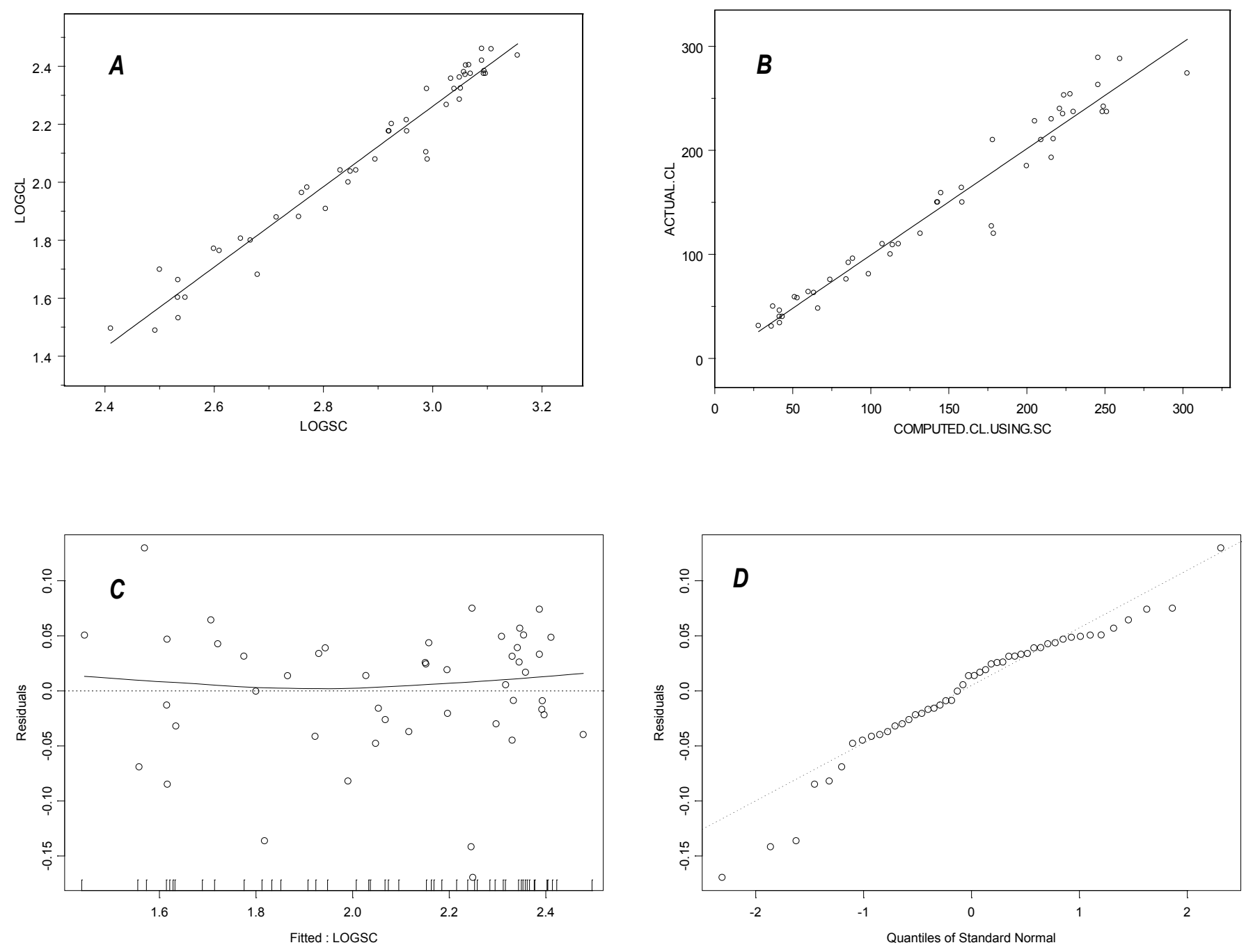

Figure 15. $S+{ }^{\circledR}$ output graphs from simple linear regression showing $A$, log-transformed specific conductance (SC) versus log-transformed chloride (CL) concentrations; $B$, computed versus actual $C L$ concentrations; $C$, computed log-transformed $C L$ concentrations versus regression residuals; and $D$, standard normal quantiles versus regression residuals for the North Fork Ninnescah River upstream from Cheney Reservoir (site 07144780), south-central Kansas, 1999 through 2009. 


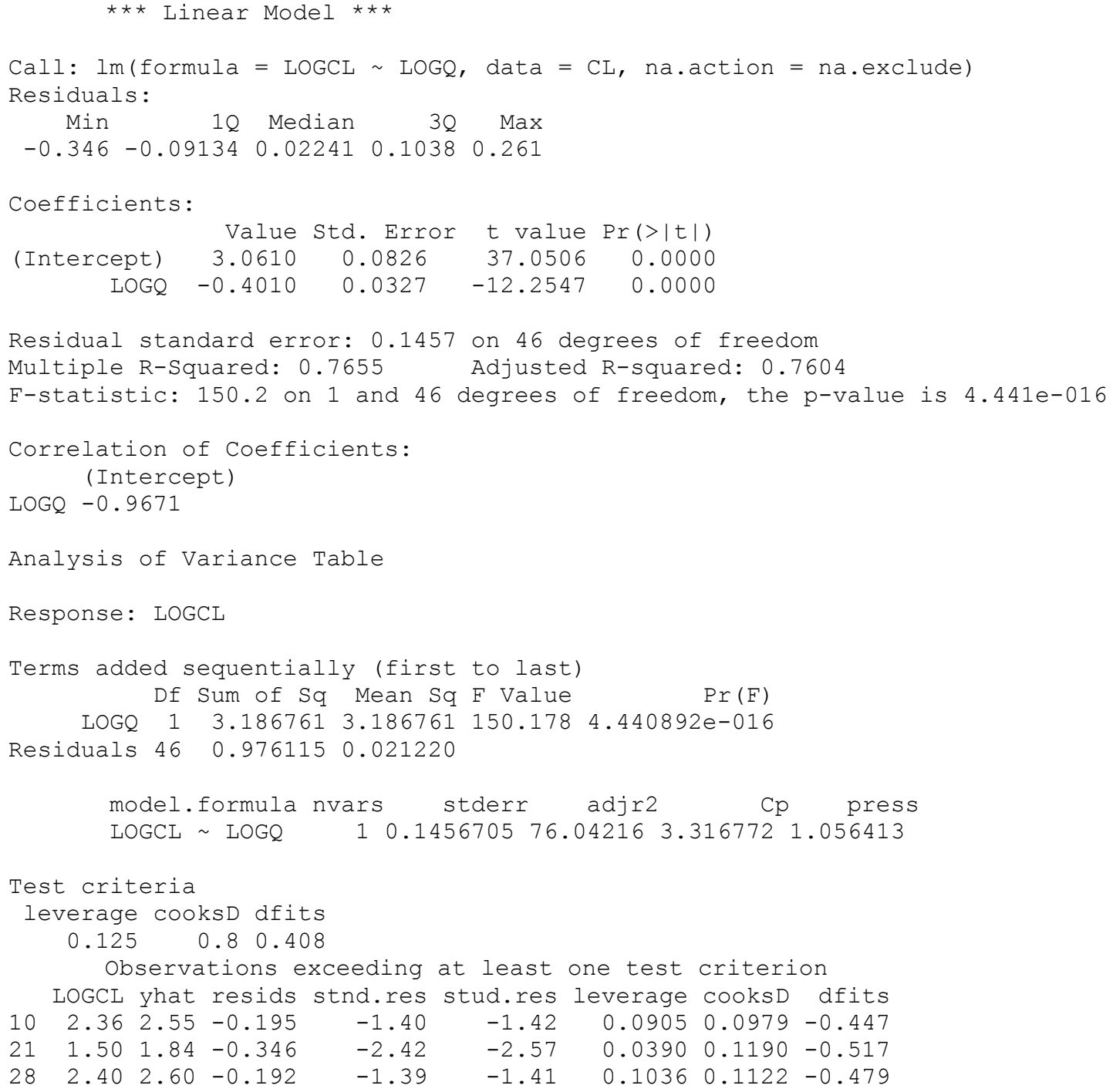

Figure 16. $\quad S+{ }^{\circledR}$ output of regression model development using streamflow $(0)$ as the explanatory variable for chloride (CL) concentrations for the North Fork Ninnescah River upstream from Cheney Reservoir (site 07144780), south-central Kansas, 1999 through 2009. 

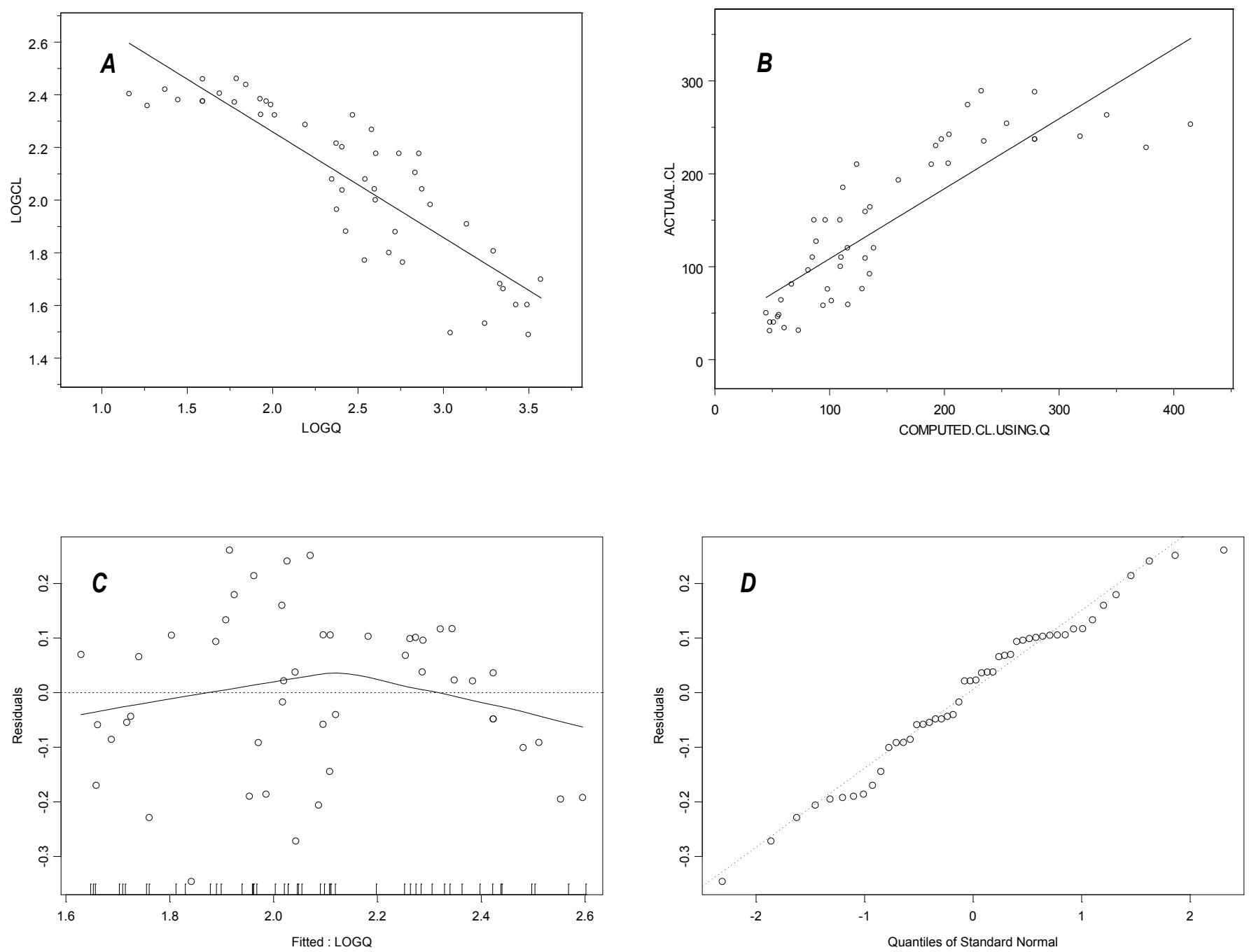

Figure 17. $S+{ }^{\oplus}$ output graphs from simple linear regression analysis showing $A$, log-transformed streamflow $(0)$ versus logtransformed chloride (CL) concentrations; $B$, computed versus actual $C L$ concentrations; $C$, computed log-transformed $C L$ concentrations versus regression residuals; and $D$, standard normal quantiles versus regression residuals for the North Fork Ninnescah River upstream from Cheney Reservoir (site 07144780), south-central Kansas, 1999 through 2009. 


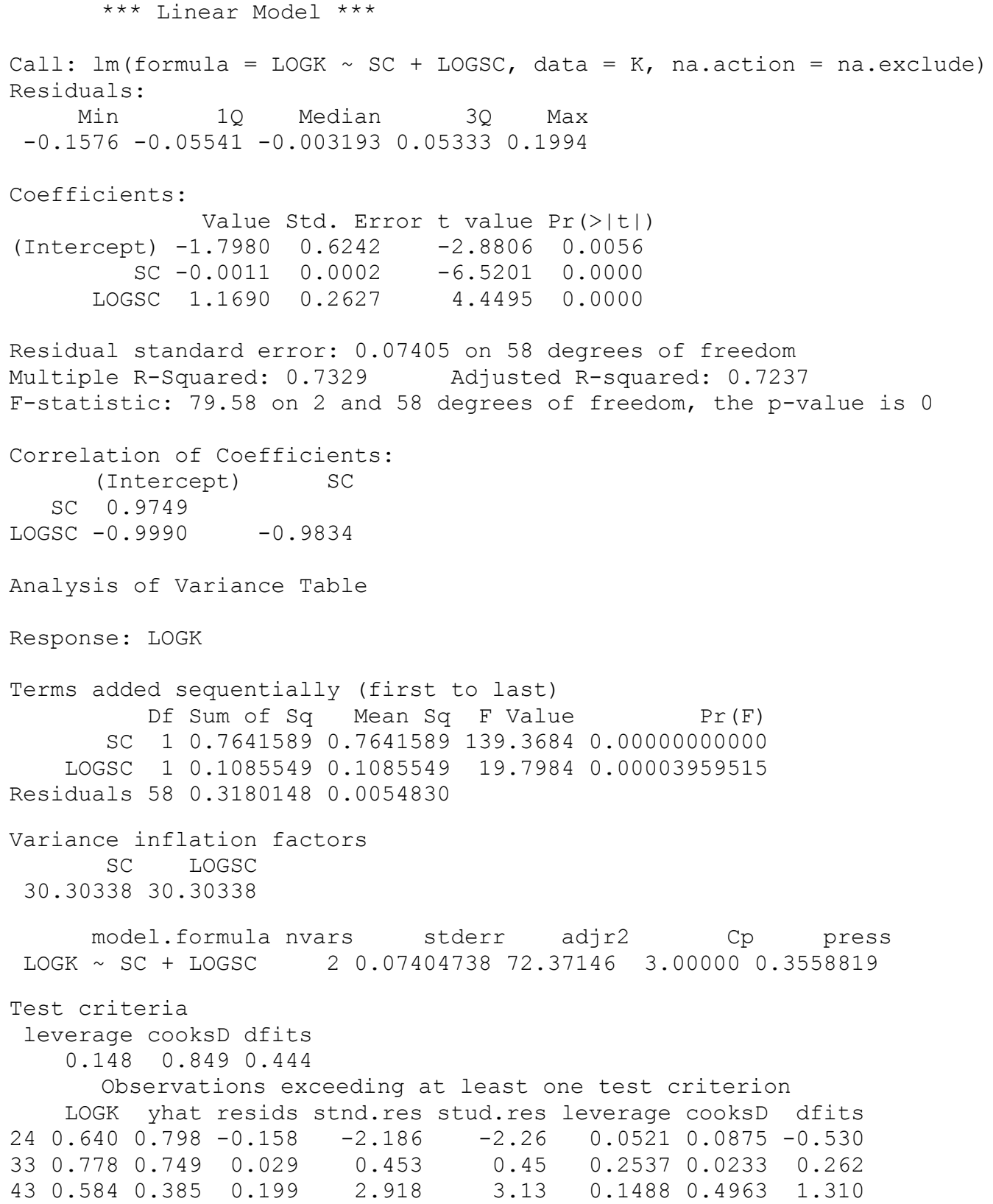

Figure 18. $\quad \mathrm{S}_{+}{ }^{\circledR}$ output of regression model development using specific conductance (SC) as an explanatory variable for potassium (K) concentrations for the North Fork Ninnescah River upstream from Cheney Reservoir (site 07144780), south-central Kansas, 1999 through 2009. 

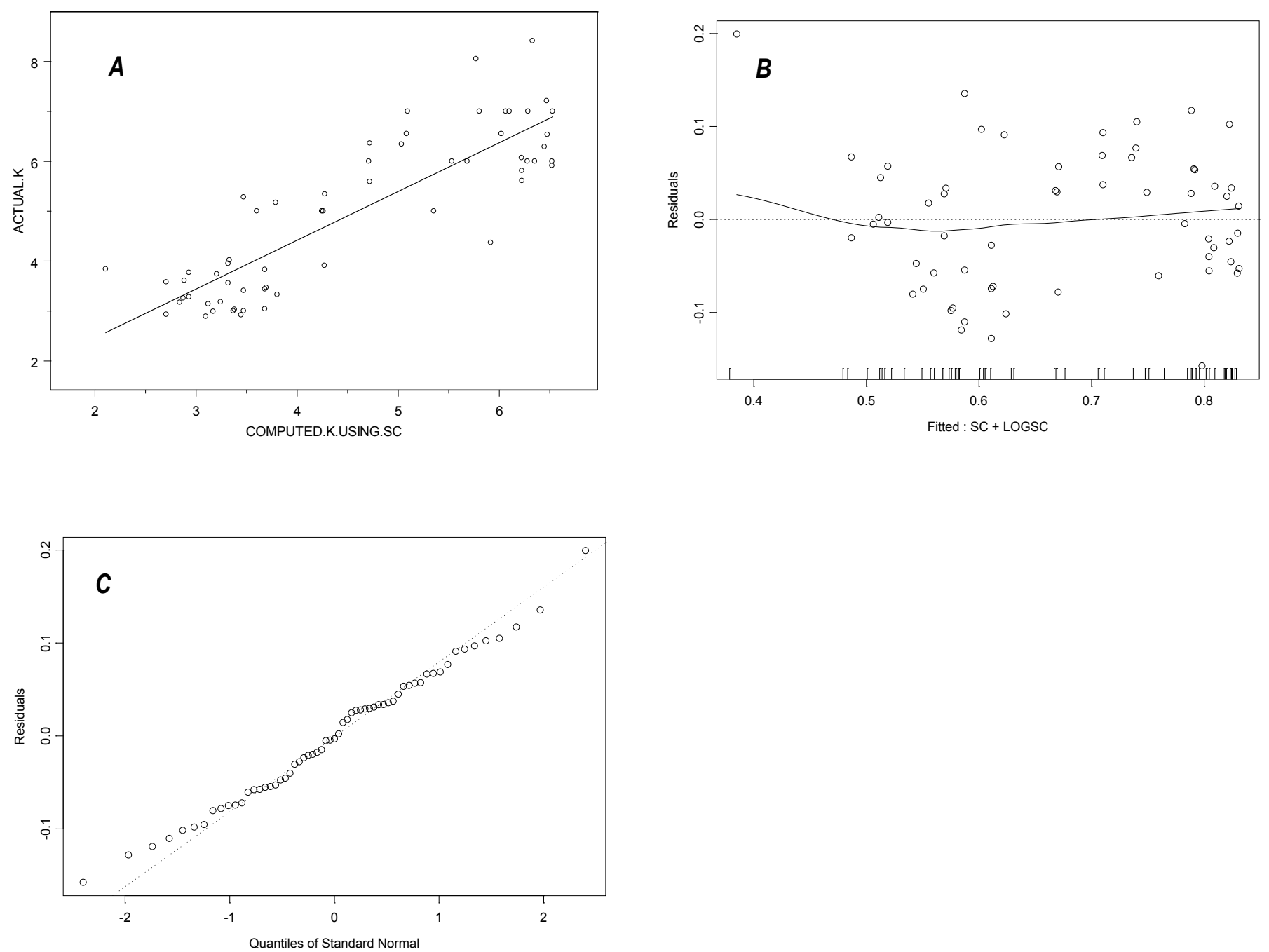

Figure 19. $\quad \mathrm{S}^{\circledR}{ }^{\oplus}$ output graphs from simple linear regression analysis using specific conductance (SC) and log-transformed $\mathrm{SC}$ as explanatory variables for potassium $(\mathrm{K})$ concentrations showing $A$, computed versus actual $\mathrm{K}$ concentrations; $B$, computed logtransformed $\mathrm{K}$ concentrations versus regression residuals; and $C$, standard normal quantiles versus regression residuals for the North Fork Ninnescah River upstream from Cheney Reservoir (site 07144780), south-central Kansas, 1999 through 2009. 


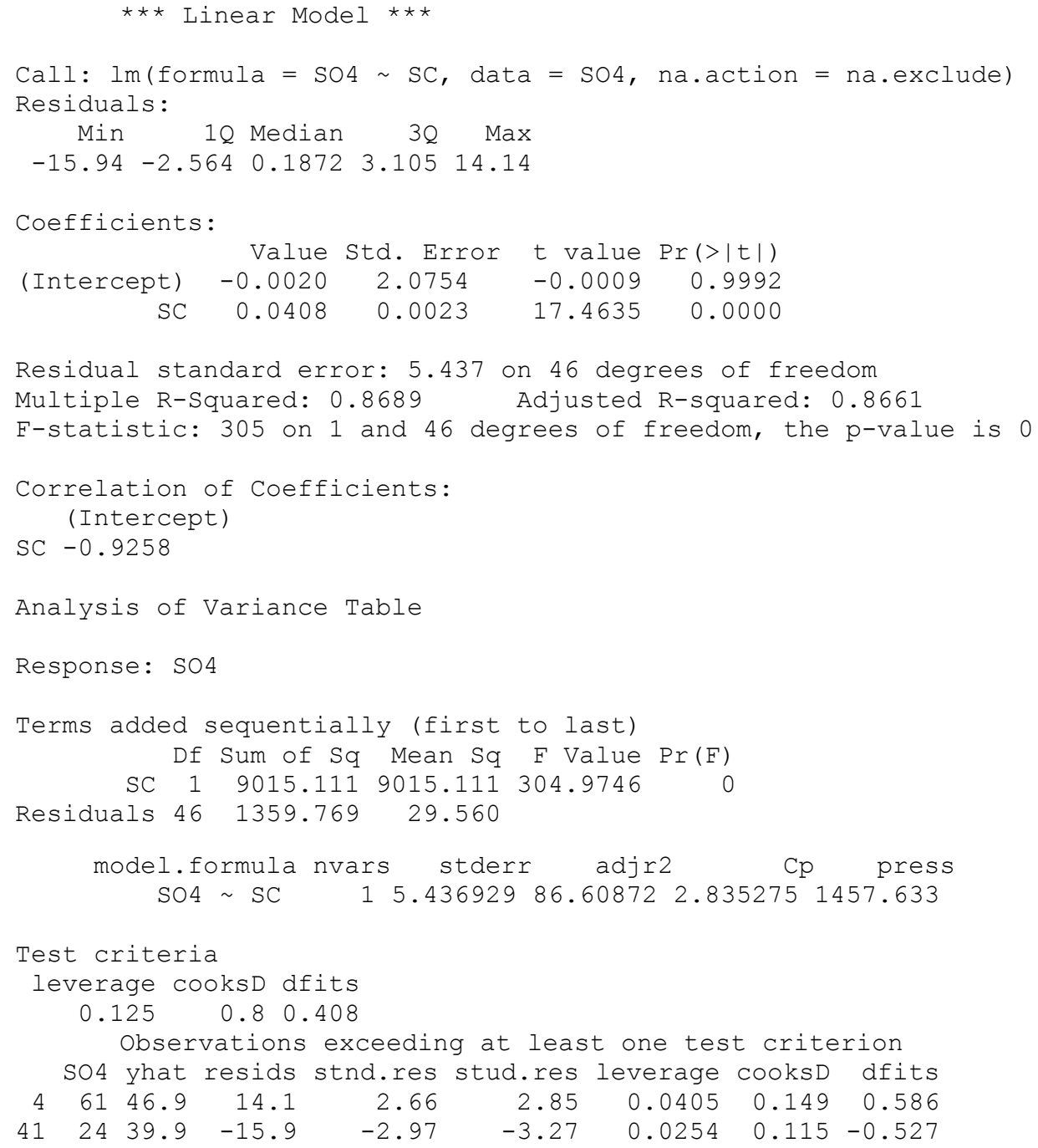

Figure 20. $S+{ }^{\circledR}$ output of regression model development using specific conductance (SC) as an explanatory variable for sulfate (SO4) concentrations for the North Fork Ninnescah River upstream from Cheney Reservoir (site 07144780), south-central Kansas, 1999 through 2009. 

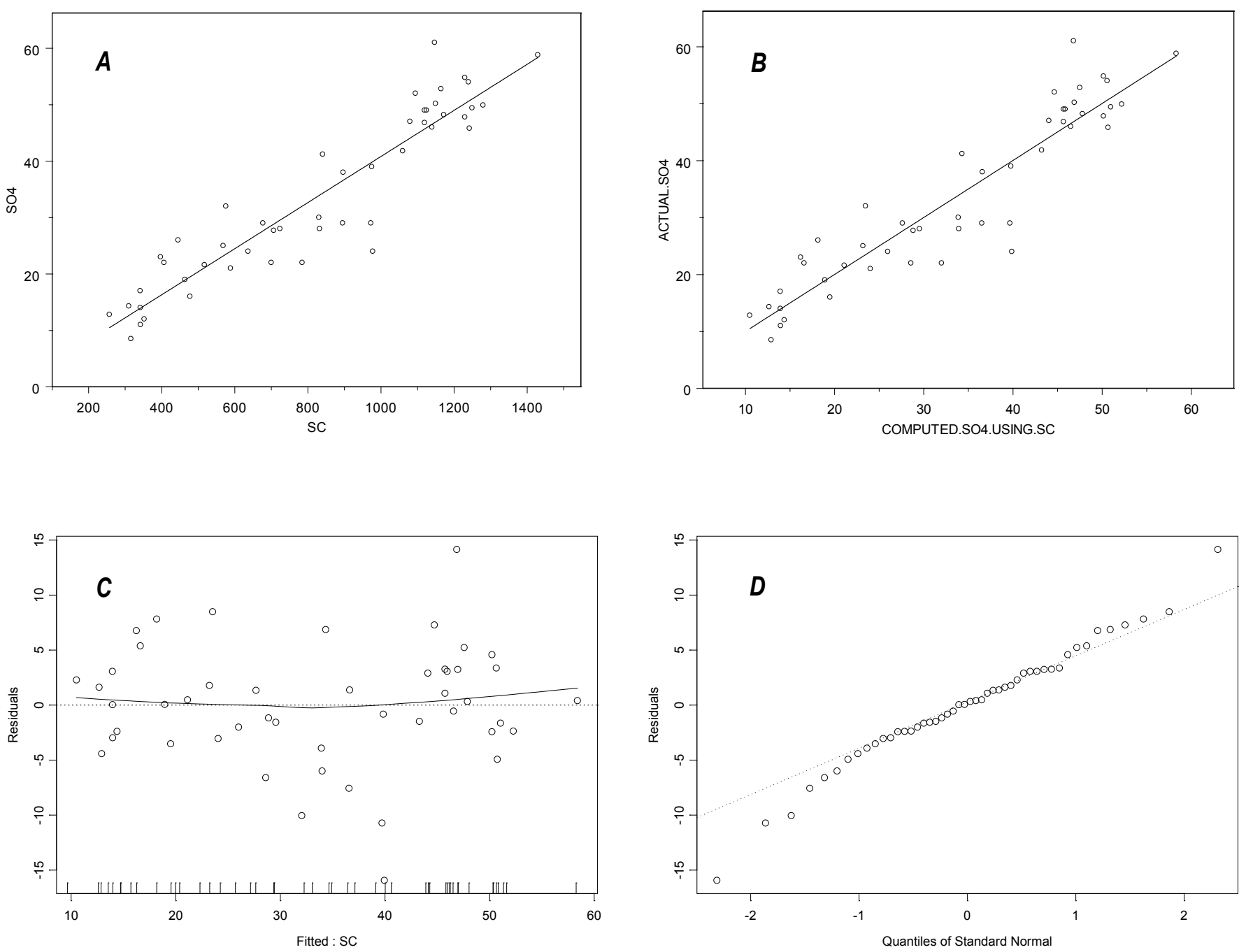

Figure 21. $\quad S+{ }^{\circledR}$ output graphs from simple linear regression analysis showing $A$, specific conductance (SC) versus sulfate (S04) concentrations; $B$, computed versus actual SO4 concentrations; $C$, computed SO4 concentrations versus regression residuals; and $D$, standard normal quantiles versus regression residuals for the North Fork Ninnescah River upstream from Cheney Reservoir (site 07144780), south-central Kansas, 1999 through 2009. 


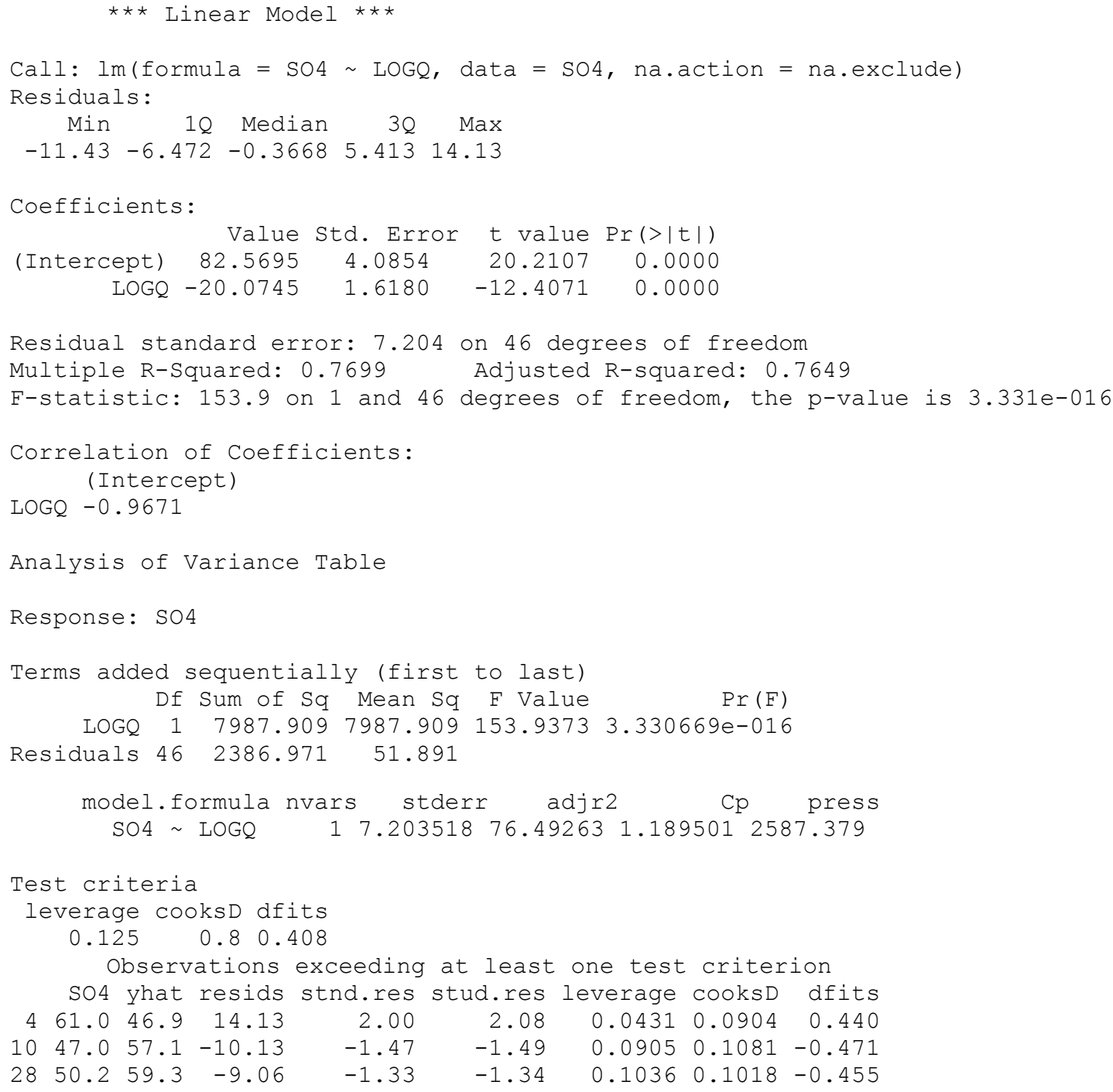

Figure 22. $\quad S_{+}{ }^{\circledR}$ output of regression model development using streamflow (0) as an explanatory variable for sulfate (SO4) concentrations for the North Fork Ninnescah River upstream from Cheney Reservoir (site 07144780), south-central Kansas, 1999 through 2009. 

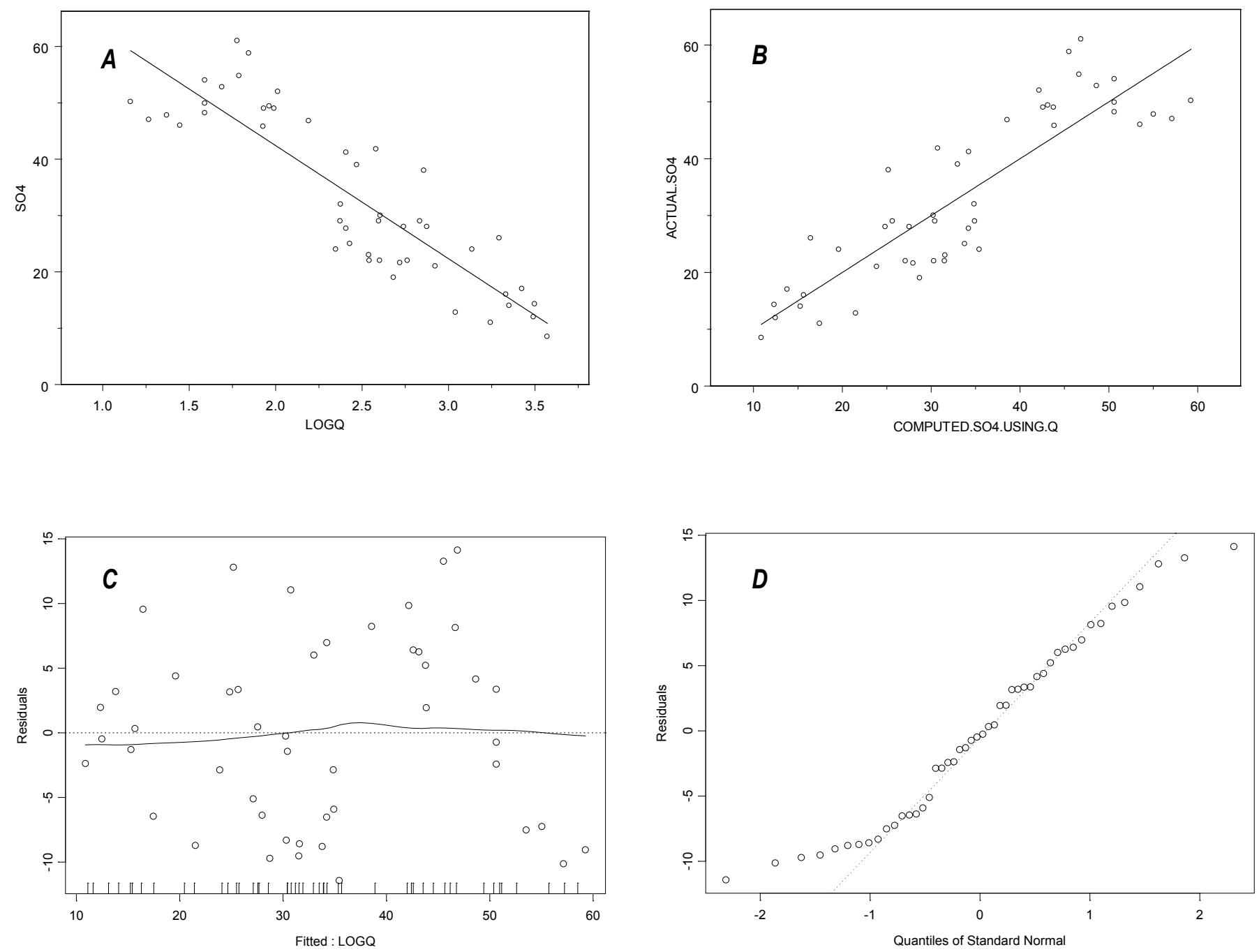

Figure 23. $S+{ }^{\circledR}$ output graphs from simple linear regression analysis showing $A$, log-transformed streamflow (0) versus sulfate (S04) concentrations; $B$, computed versus actual SO4 concentrations; $C$, computed SO4 concentrations versus regression residuals; and $D$, standard normal quantiles versus regression residuals for the North Fork Ninnescah River upstream from Cheney Reservoir (site 07144780), south-central Kansas, 1999 through 2009. 


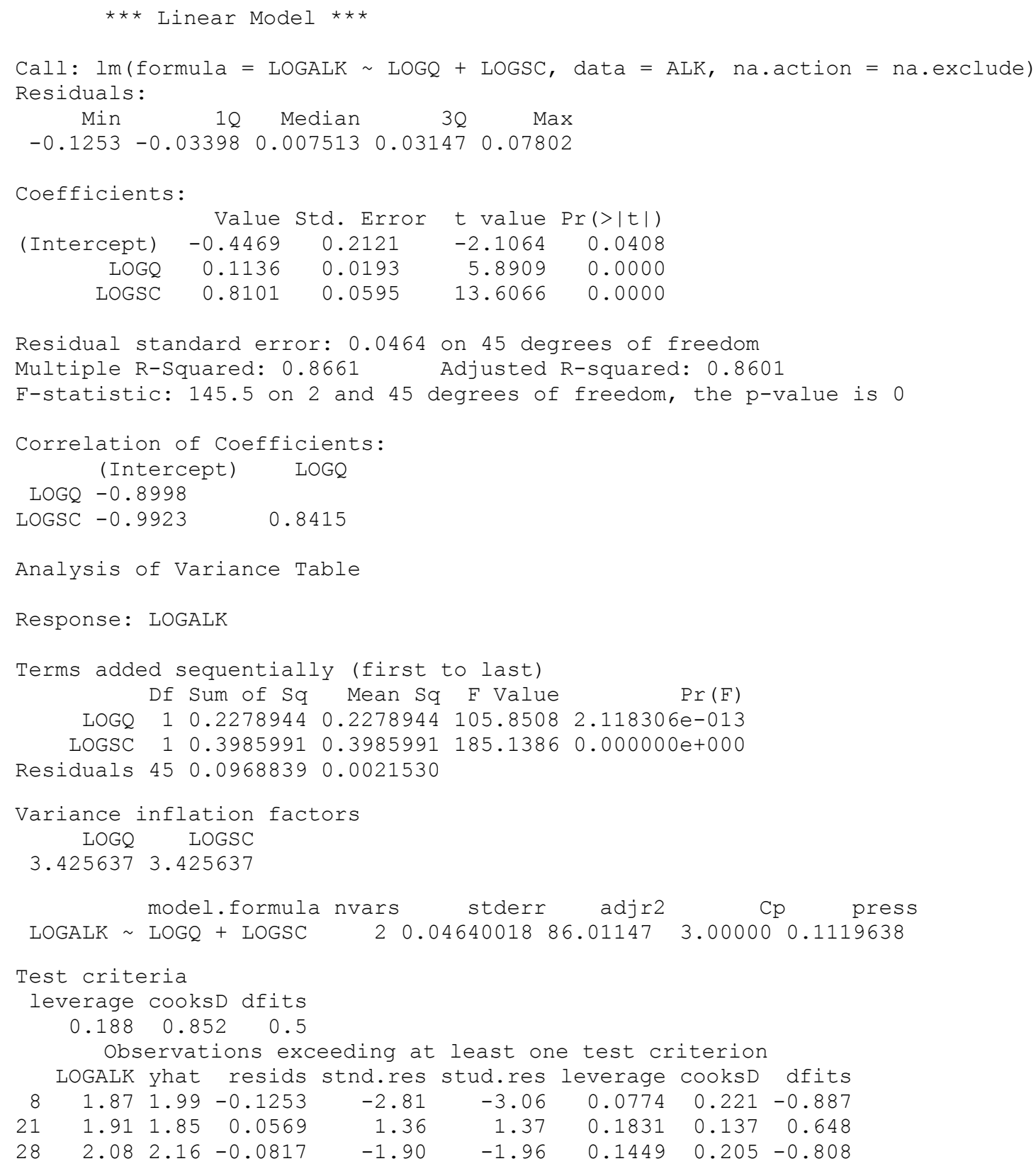

Figure 24. $S+{ }^{\oplus}$ output of regression model development using streamflow (0) and specific conductance (SC) as explanatory variables for alkalinity (ALK) concentrations for the North Fork Ninnescah River upstream from Cheney Reservoir (site 07144780), south-central Kansas, 1999 through 2009. 

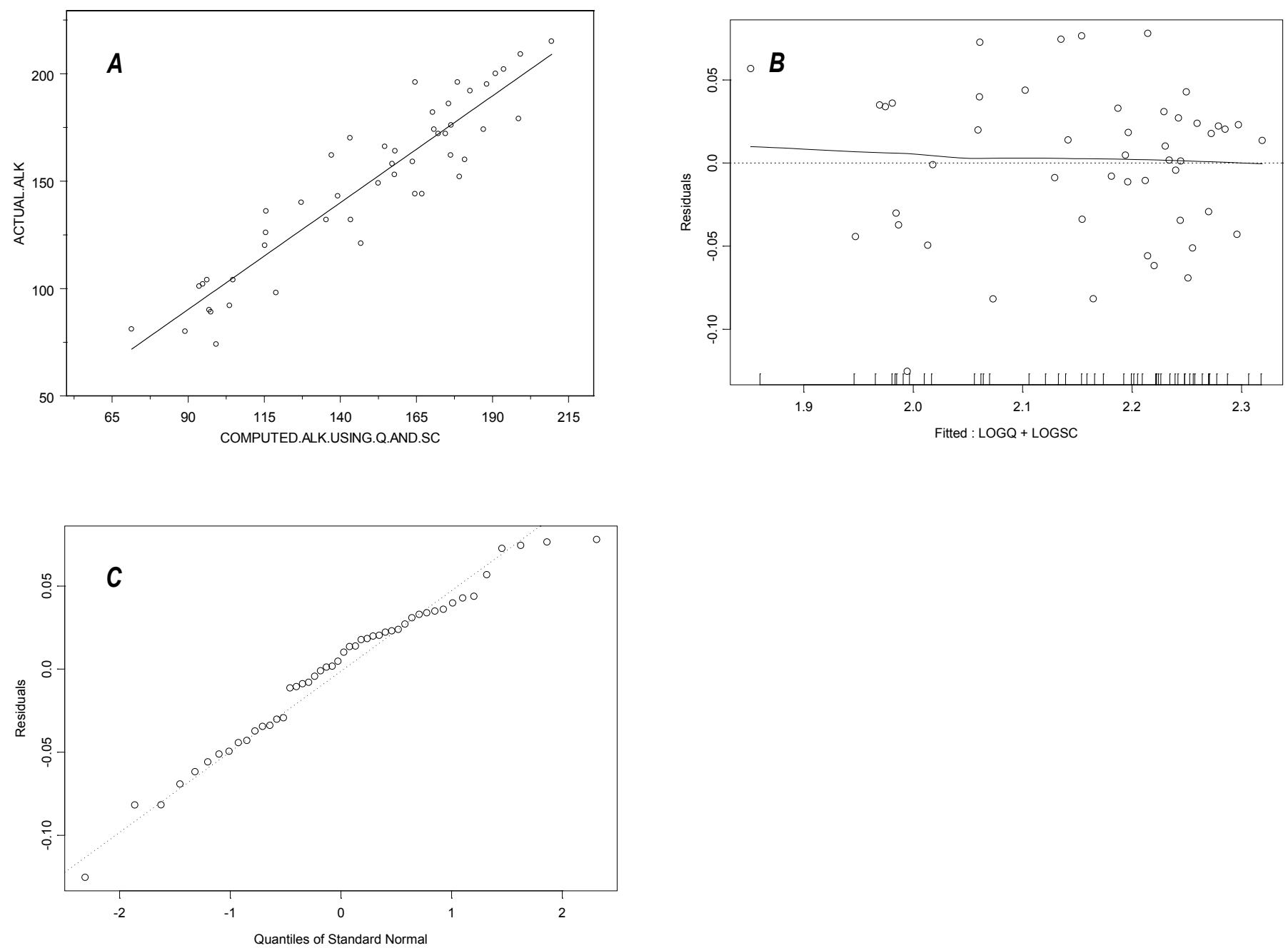

Figure 25. $\quad S+{ }^{\circledR}$ output graphs from simple linear regression analysis using streamflow $(0)$ and specific conductance (SC) as explanatory variables for alkalinity (ALK) concentrations showing $A$, computed versus actual ALK concentrations; $B$, computed logtransformed ALK concentrations versus regression residuals; and $C$, standard normal quantiles versus regression residuals for the North Fork Ninnescah River upstream from Cheney Reservoir (site 07144780), south-central Kansas, 1999 through 2009. 


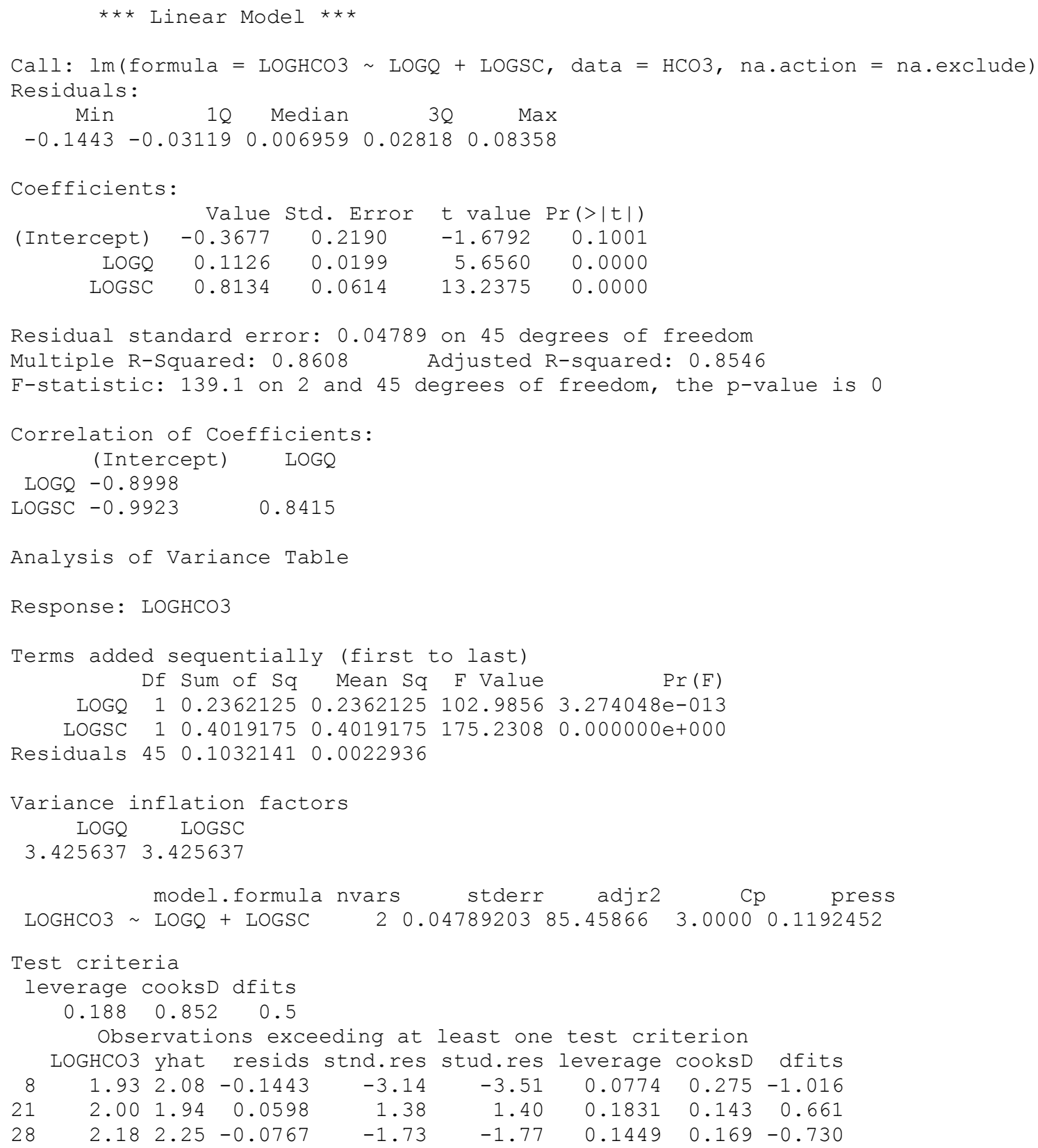

Figure 26. $\quad S+{ }^{\circledR}$ output of regression model development using streamflow ( 0 ) and specific conductance (SC) as explanatory variables for bicarbonate ( $\mathrm{HCO}$ ) concentrations for the North Fork Ninnescah River upstream from Cheney Reservoir (site 07144780), south-central Kansas, 1999 through 2009. 

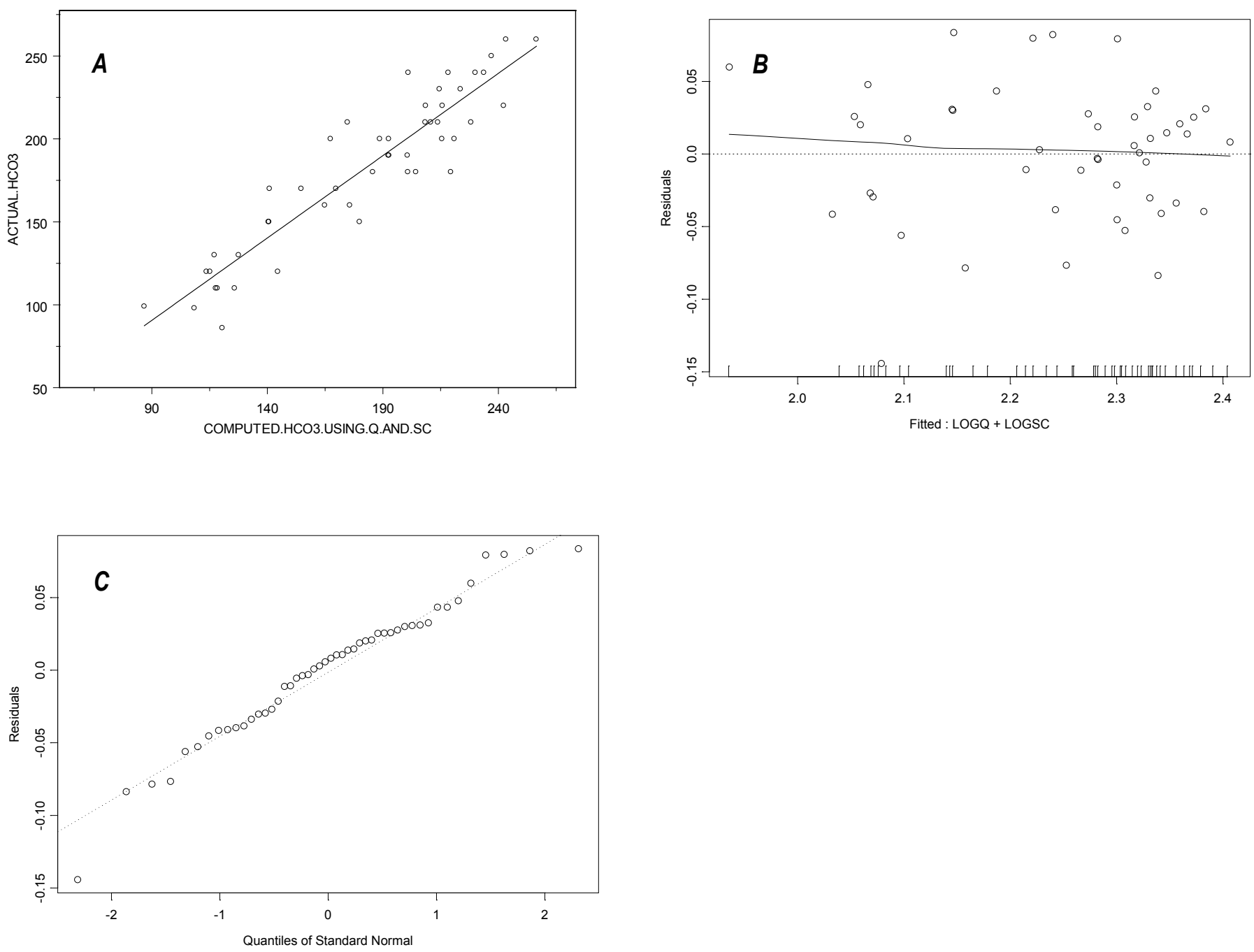

Figure 27. $S+{ }^{\circledR}$ output graphs from simple linear regression analysis using streamflow (0) and specific conductance (SC) as explanatory variables for bicarbonate ( $\mathrm{HCO}$ ) concentrations showing $A$, computed versus actual $\mathrm{HCO}$ concentrations; $B$, computed log-transformed $\mathrm{HCO} 3$ concentrations versus regression residuals, and $C$, standard normal quantiles versus regression residuals for the North Fork Ninnescah River upstream from Cheney Reservoir (site 07144780), south-central Kansas, 1999 through 2009. 


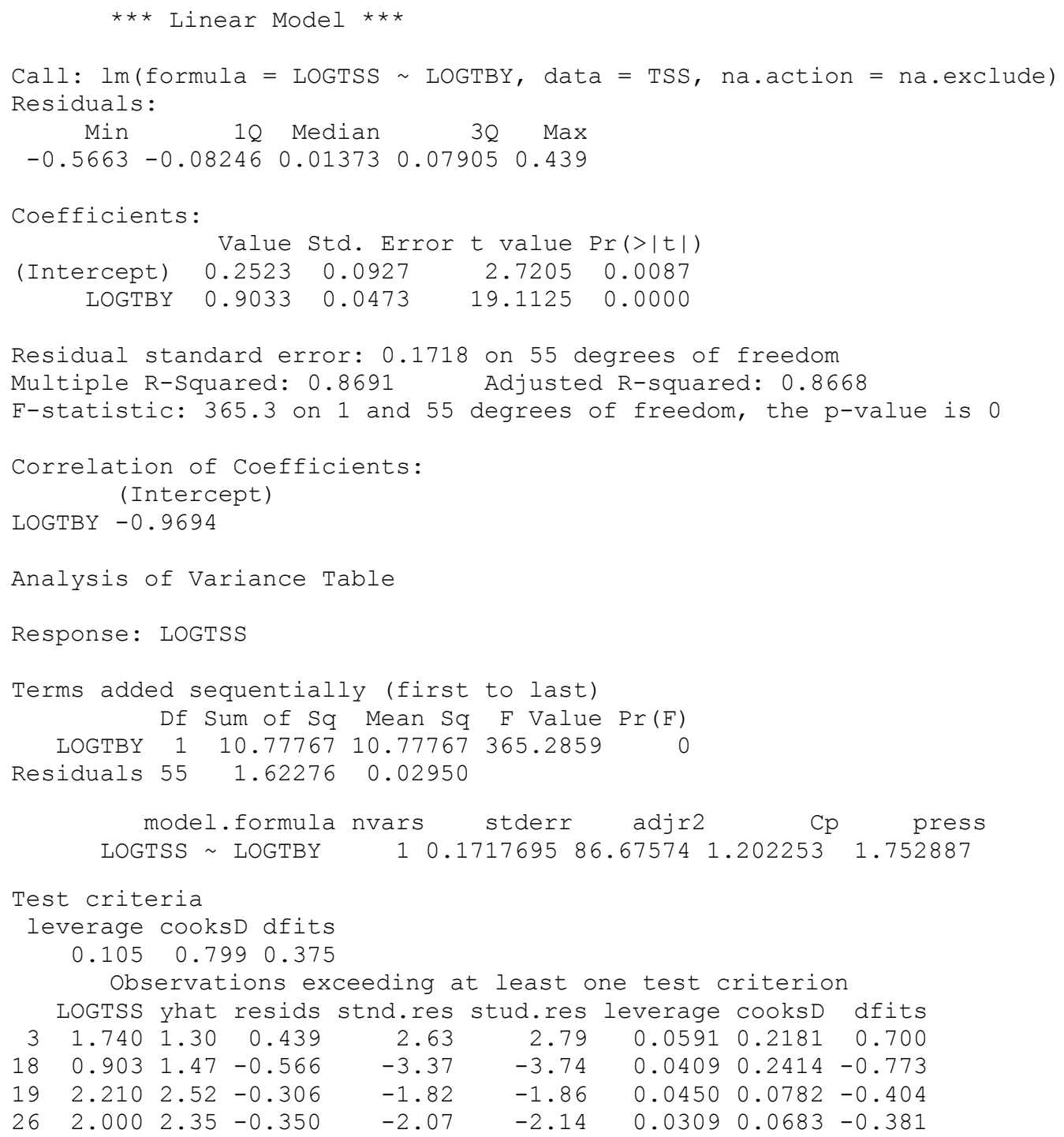

Figure 28. $\quad S+{ }^{\circledR}$ output of regression model development using turbidity (TBY) as an explanatory variable for total suspended solids (TSS) concentrations for the North Fork Ninnescah River upstream from Cheney Reservoir (site 07144780), south-central Kansas, 1999 through 2009. 

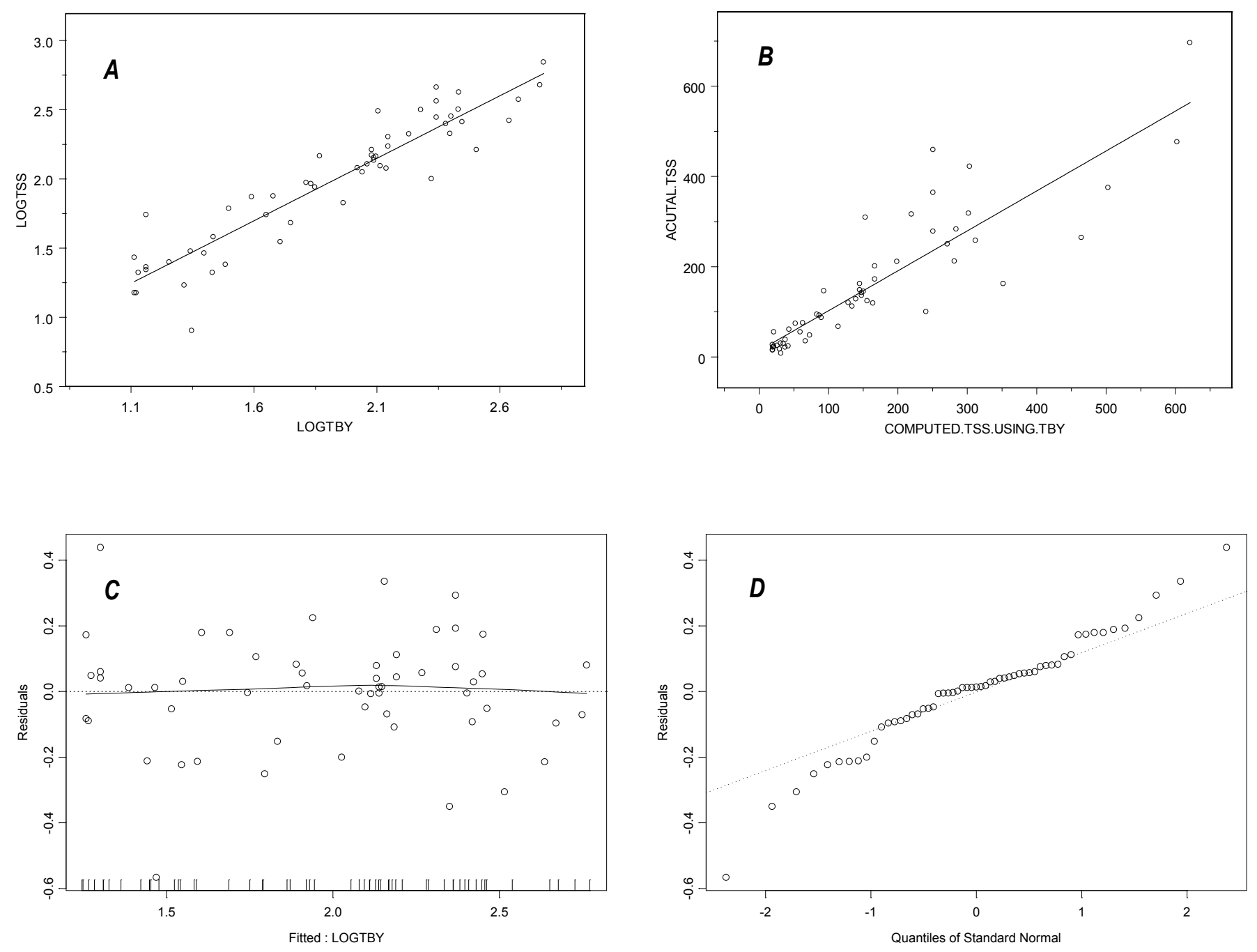

Figure 29. $S+{ }^{\circledR}$ output graphs from simple linear regression analysis showing $A$, log-transformed turbidity (TBY) versus log-transformed total suspended solids (TSS) concentrations; $B$, computed versus actual TSS concentrations; $C$, computed log-transformed TSS concentrations versus regression residuals; and $D$, standard normal quantiles versus regression residuals for the North Fork Ninnescah River upstream from Cheney Reservoir (site 07144780), south-central Kansas, 1999 through 2009. 


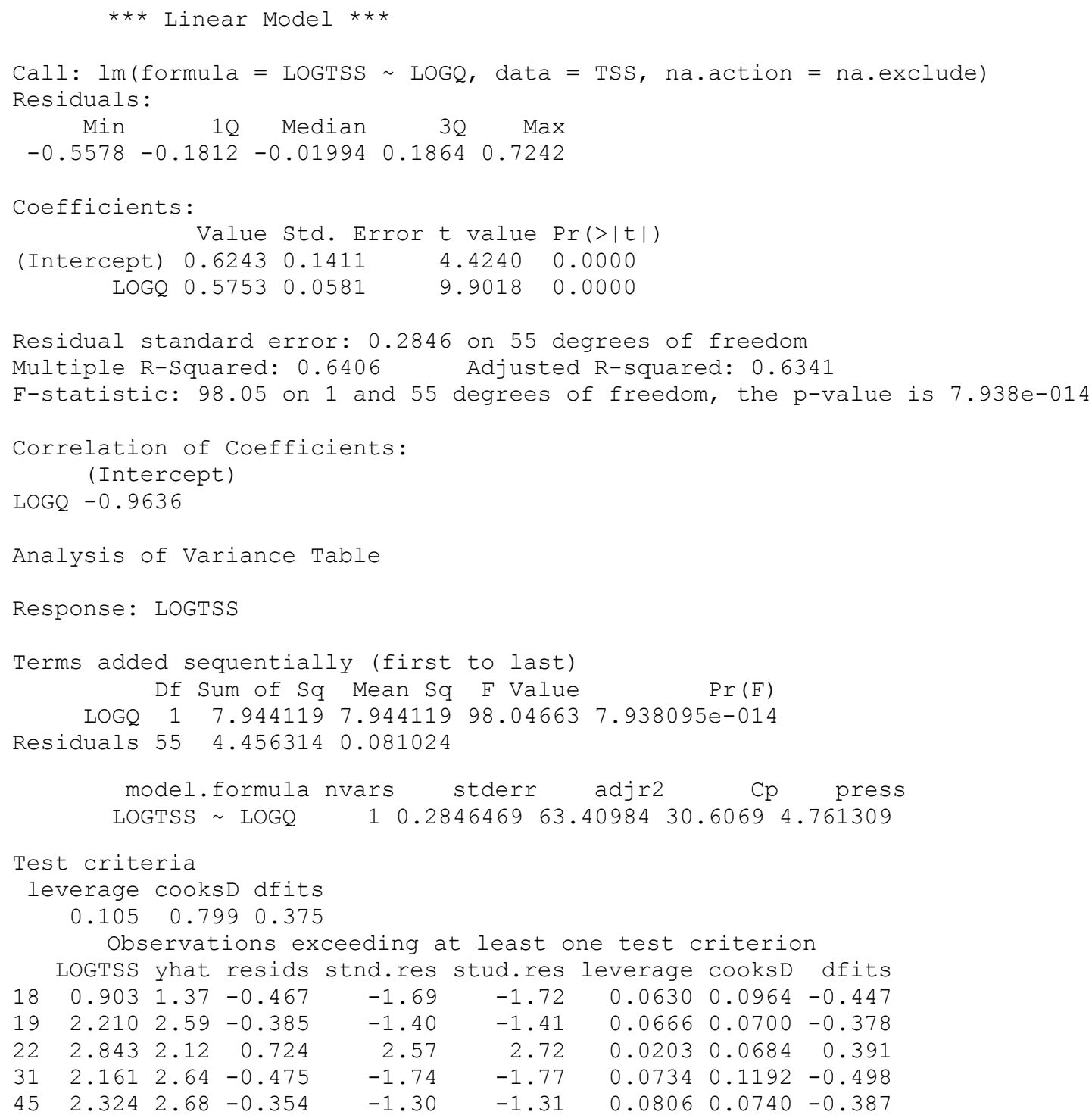

Figure 30. $S+{ }^{\circledR}$ output of regression model development using streamflow $(0)$ as an explanatory variable for total suspended solids (TSS) concentrations for the North Fork Ninnescah River upstream from Cheney Reservoir (site 07144780), south-central Kansas, 1999 through 2009. 

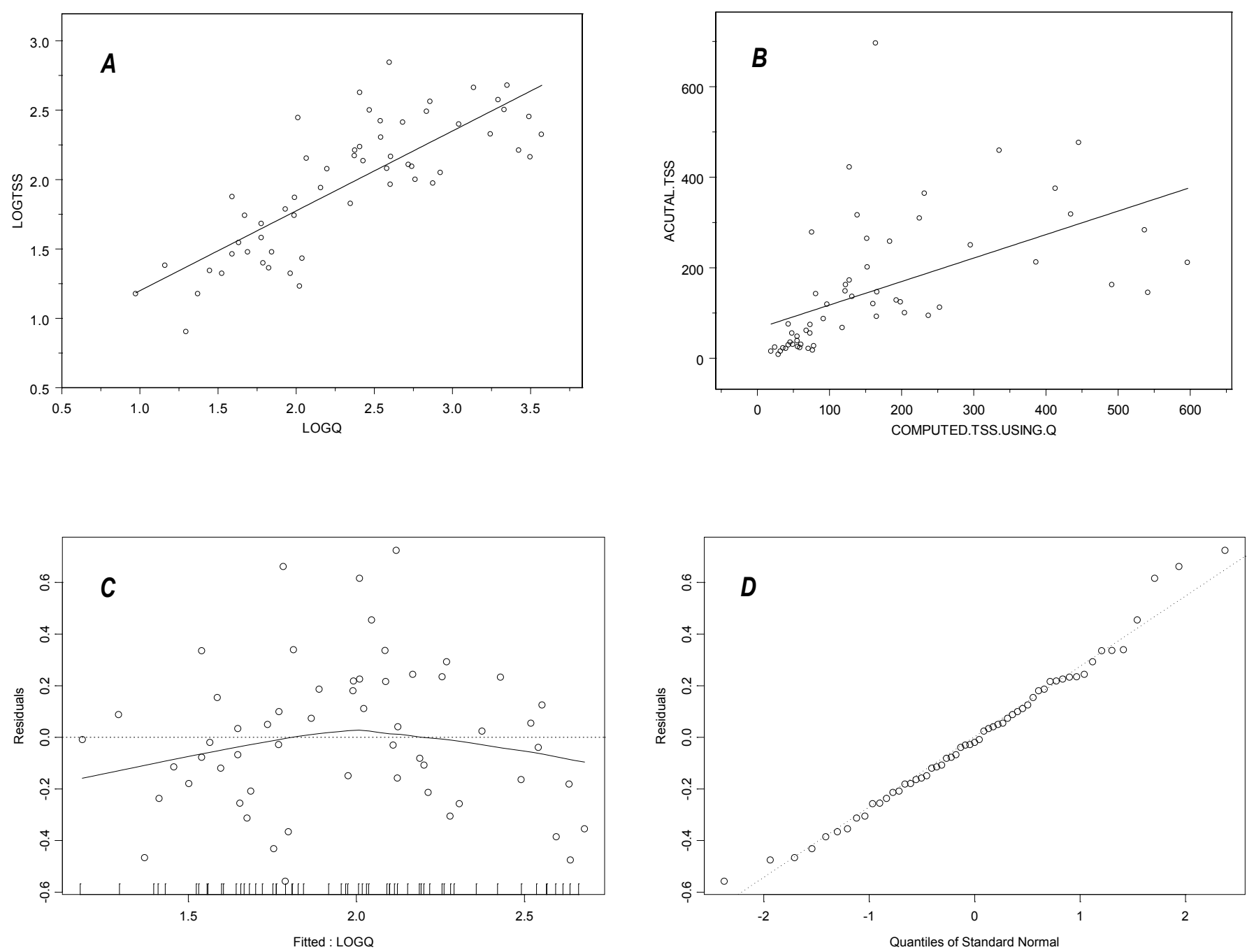

Figure 31. $S+^{\oplus}$ output graphs from simple linear regression analysis showing $A$, log-transformed streamflow $(0)$ versus logtransformed total suspended solids (TSS) concentrations; $B$, computed versus actual TSS concentrations; $C$, computed log-transformed TSS concentrations versus regression residuals; and $D$, standard normal quantiles versus regression residuals for the North Fork Ninnescah River upstream from Cheney Reservoir (site 07144780), south-central Kansas, 1999 through 2009. 


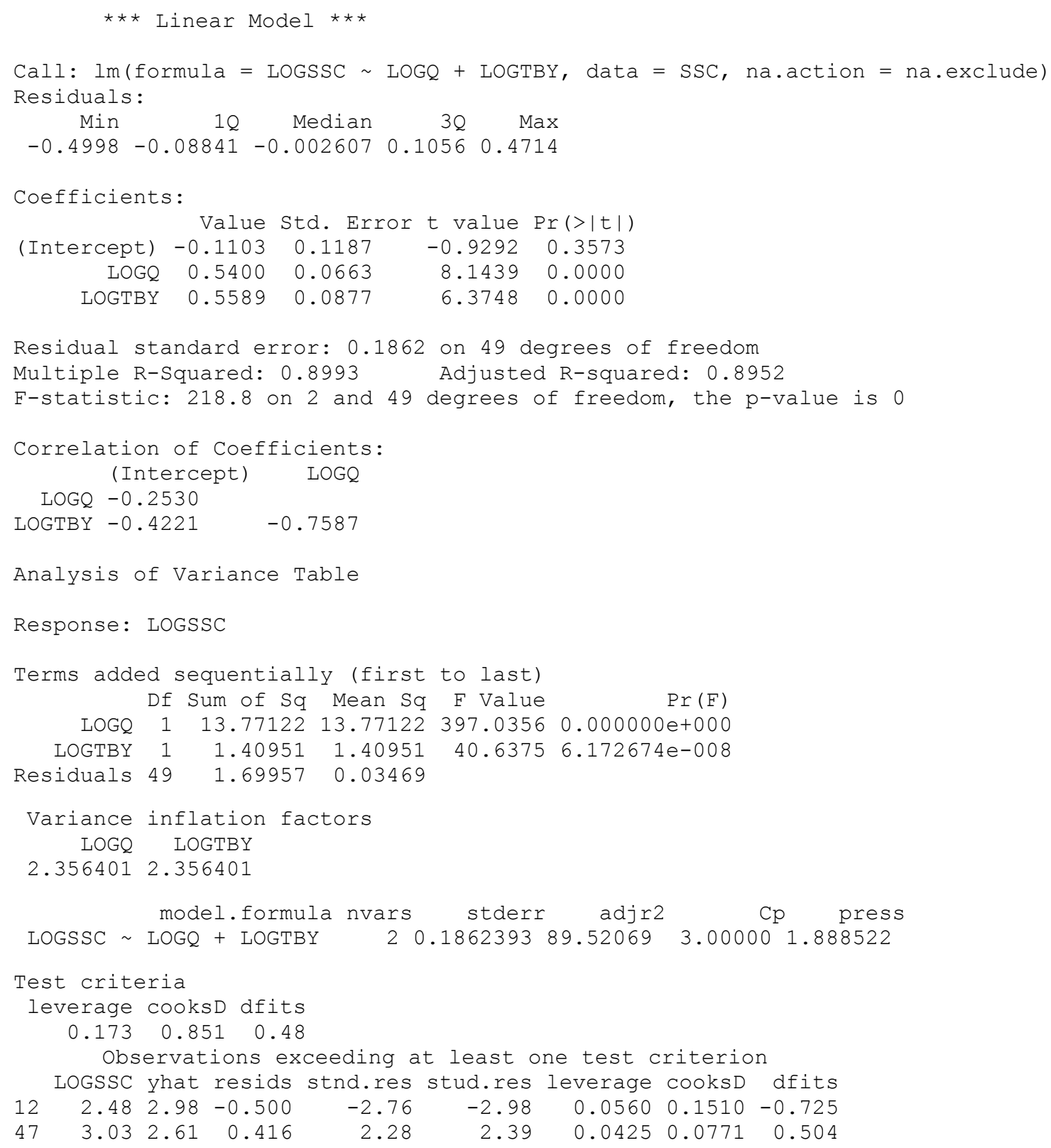

Figure 32. $\quad S+{ }^{\circledR}$ output of regression model development using streamflow $(0)$ and turbidity (TBY) as explanatory variables for suspended-sediment concentrations (SSC) for the North Fork Ninnescah River upstream from Cheney Reservoir (site 07144780), south-central Kansas, 1999 through 2009. 

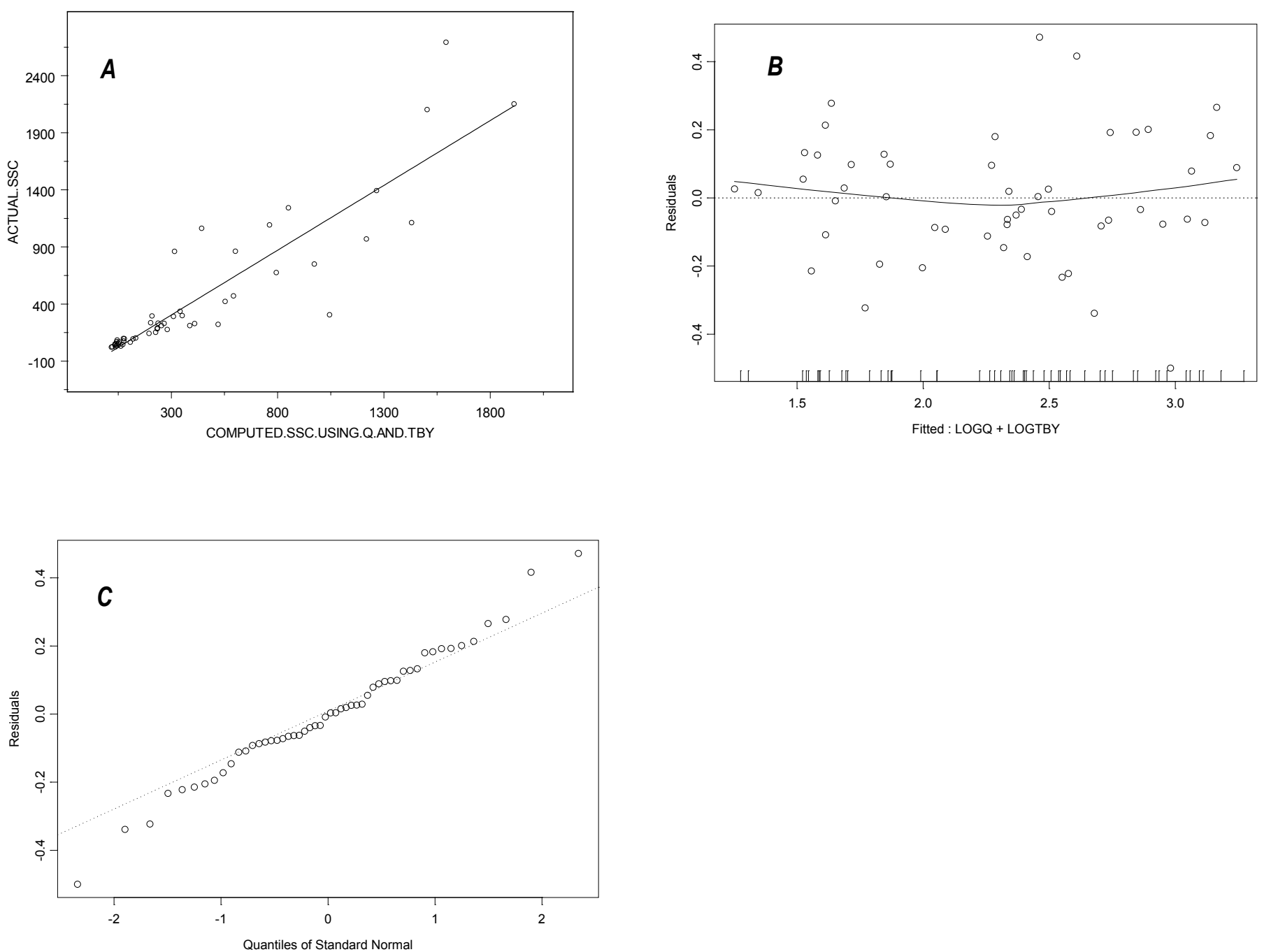

Figure 33. $S+{ }^{\circledR}$ output graphs from simple linear regression analysis using streamflow $(0)$ and turbidity (TBY) as explanatory variables for suspended-sediment concentrations (SSC) showing $A$, computed versus actual SSC concentrations; $B$, computed log-transformed SSC versus regression residuals; and $C$, standard normal quantiles versus regression residuals for the North Fork Ninnescah River upstream from Cheney Reservoir (site 07144780), south-central Kansas, 1999 through 2009. 


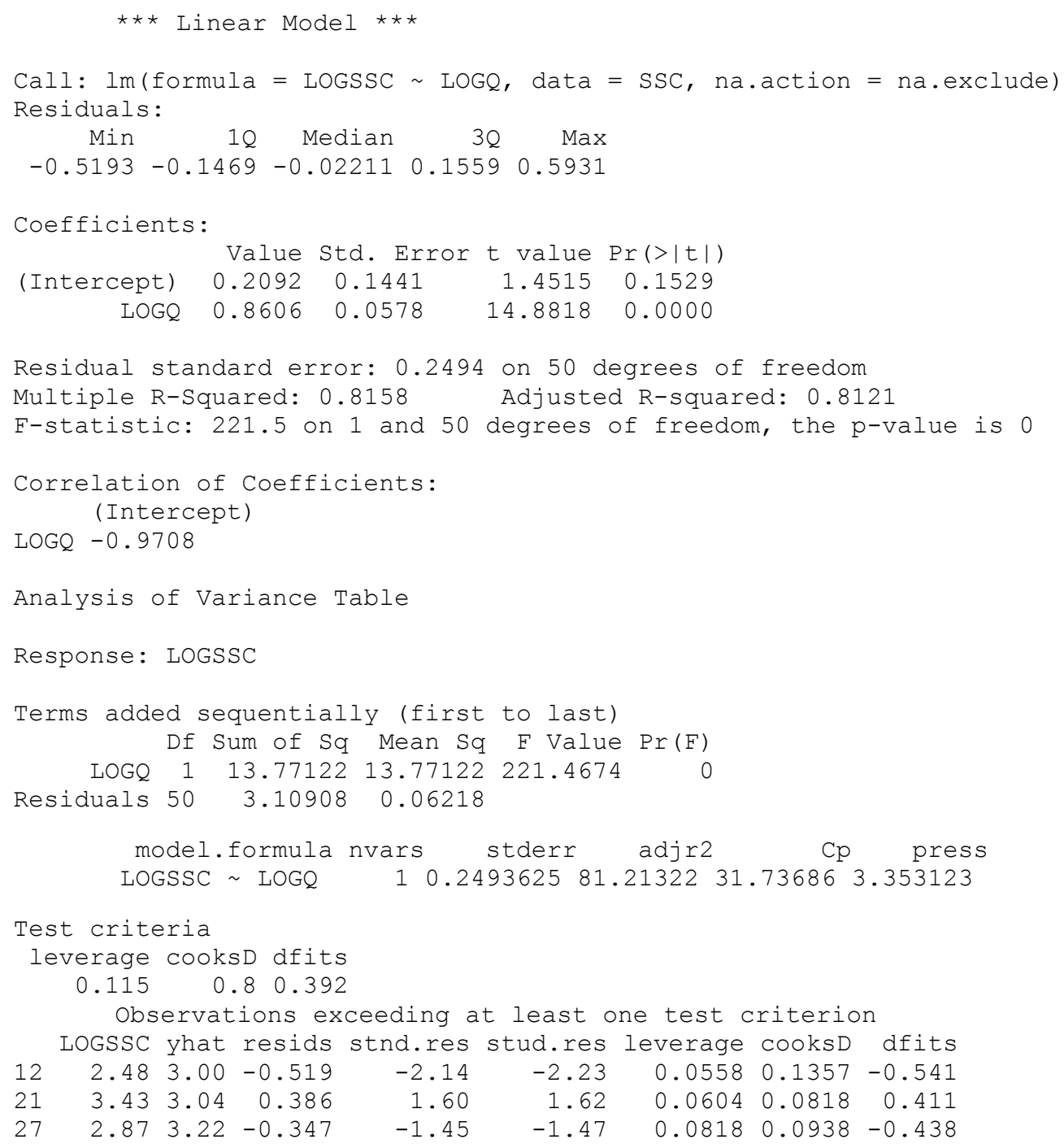

Figure 34. $S+{ }^{\circledR}$ output of regression model development using streamflow $(0)$ as an explanatory variable for suspended-sediment concentrations (SSC) for the North Fork Ninnescah River upstream from Cheney Reservoir (site 07144780), south-central Kansas, 1999 through 2009. 

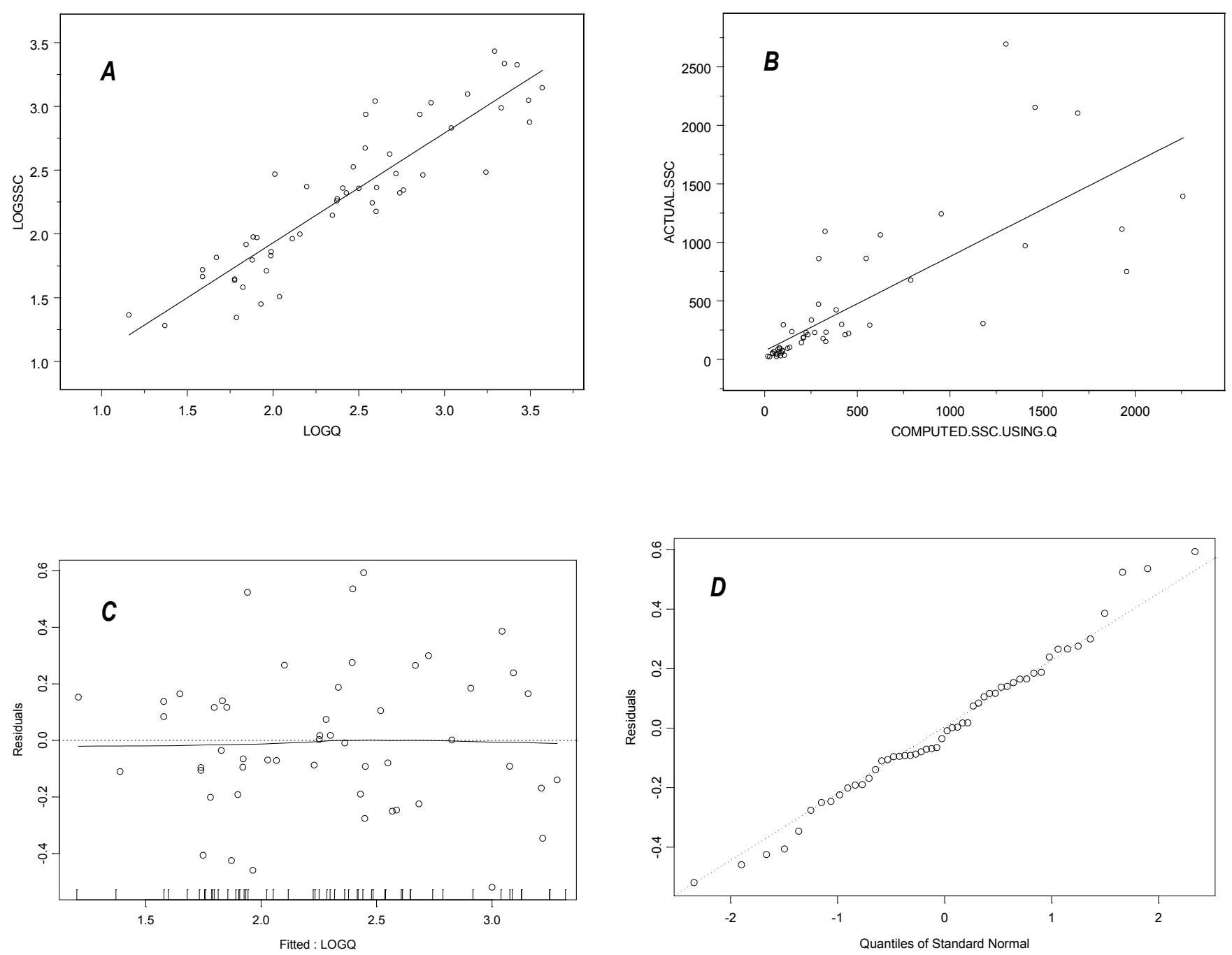

Figure 35. $\quad \mathrm{S}+{ }^{\circledR}$ output graphs from simple linear regression analysis showing $A$, log-transformed streamflow $(0)$ versus logtransformed suspended-sediment concentrations (SSC); $B$, computed versus actual SSC concentrations; $C$, computed log-transformed SSC versus regression residuals; and $D$, standard normal quantiles versus regression residuals for the North Fork Ninnescah River upstream from Cheney Reservoir (site 07144780), south-central Kansas, 1999 through 2009. 


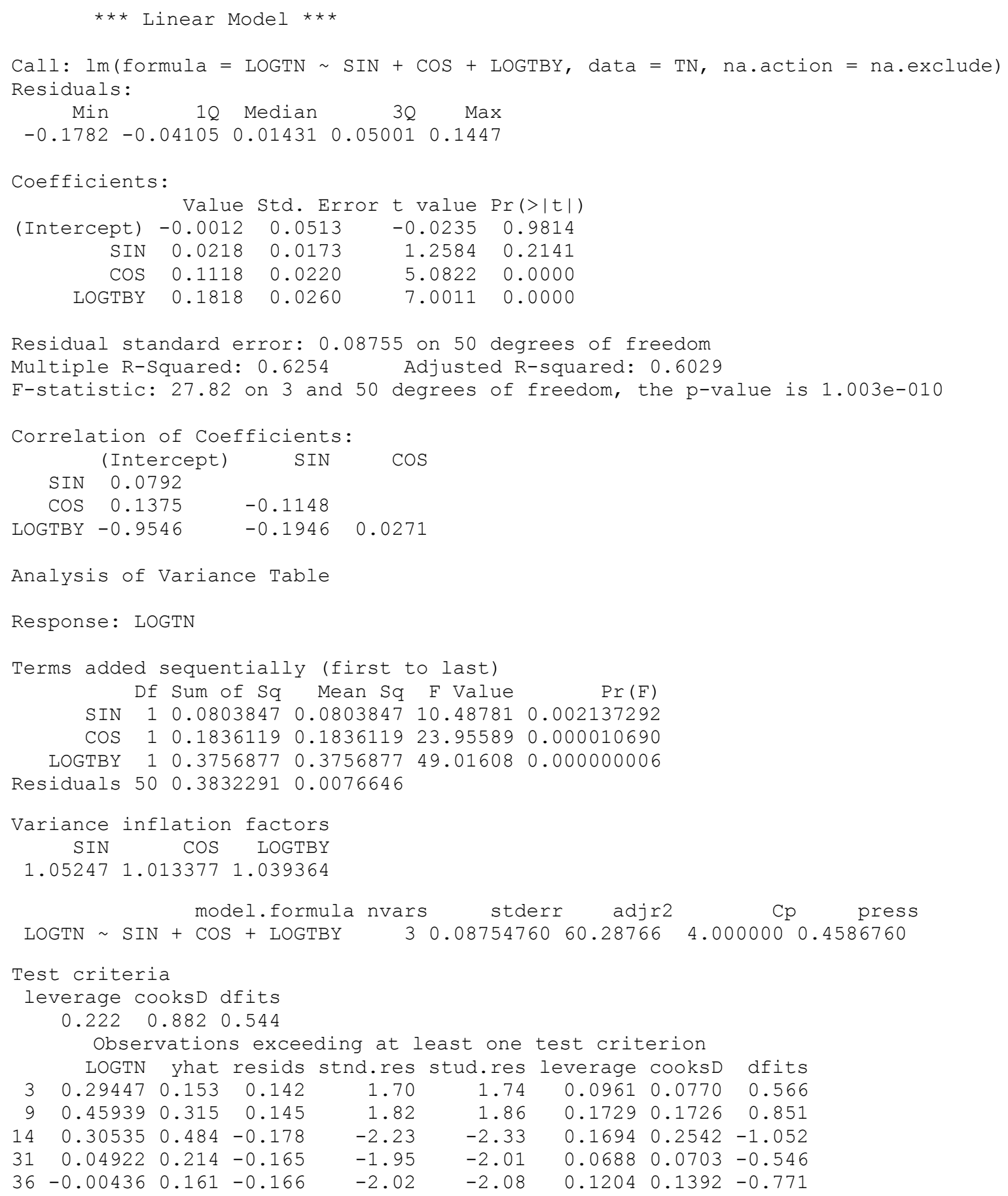

Figure 36. S $+^{\oplus}$ output of regression model development using season (SIN and COS) and turbidity (TBY) as explanatory variables for total nitrogen (TN) concentrations for the North Fork Ninnescah River upstream from Cheney Reservoir (site 07144780), south-central Kansas, 1999 through 2009. 

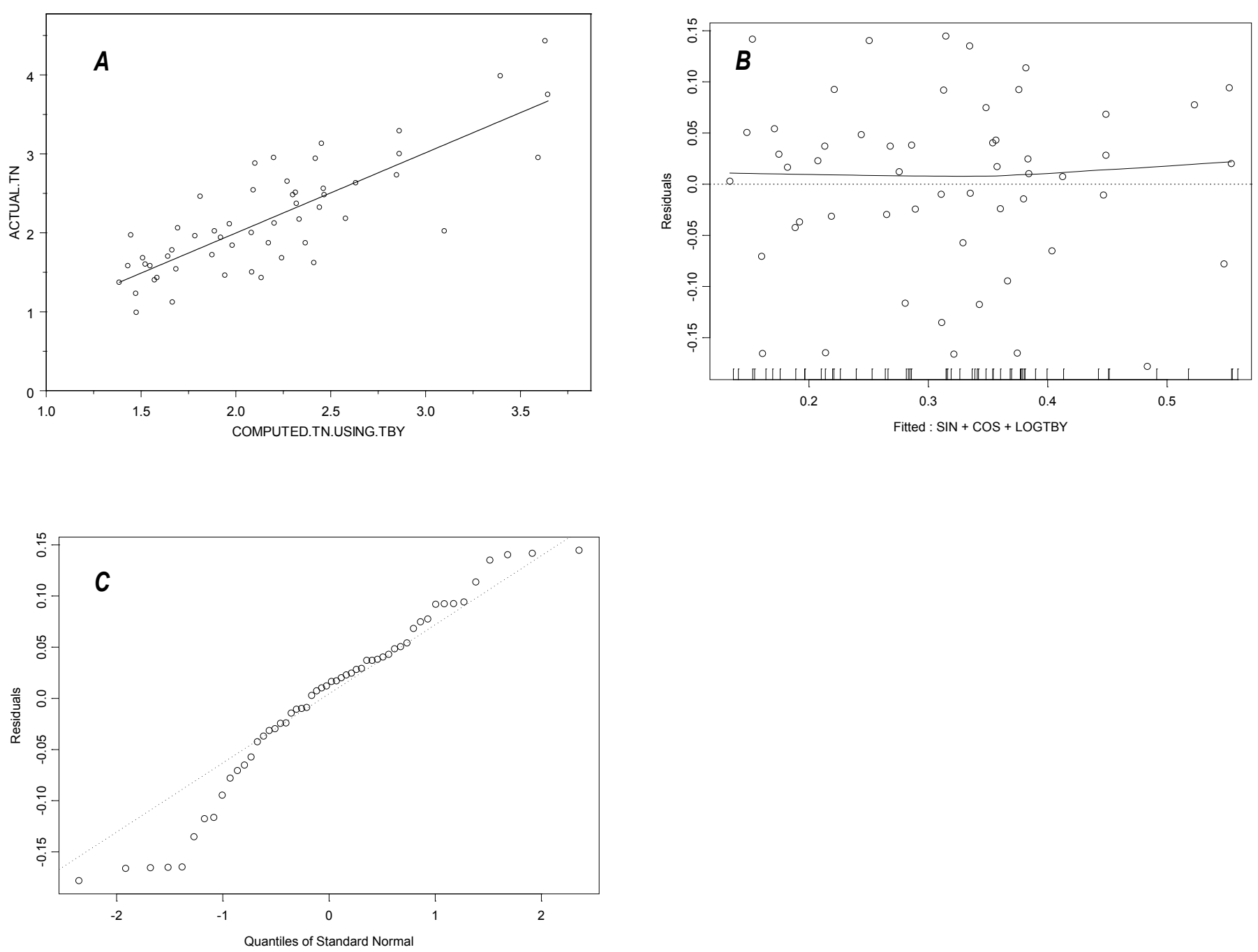

Figure 37. $S+{ }^{\circledR}$ output graphs from simple linear regression analysis using season (SIN and COS) and turbidity (TBY) as explanatory variables for total nitrogen (TN) concentrations showing $A$, computed versus actual TN concentrations; $B$, computed log-transformed TN concentrations versus regression residuals; and $C$, standard normal quantiles versus regression residuals for the North Fork Ninnescah River upstream from Cheney Reservoir (site 07144780), south-central Kansas, 1999 through 2009. 


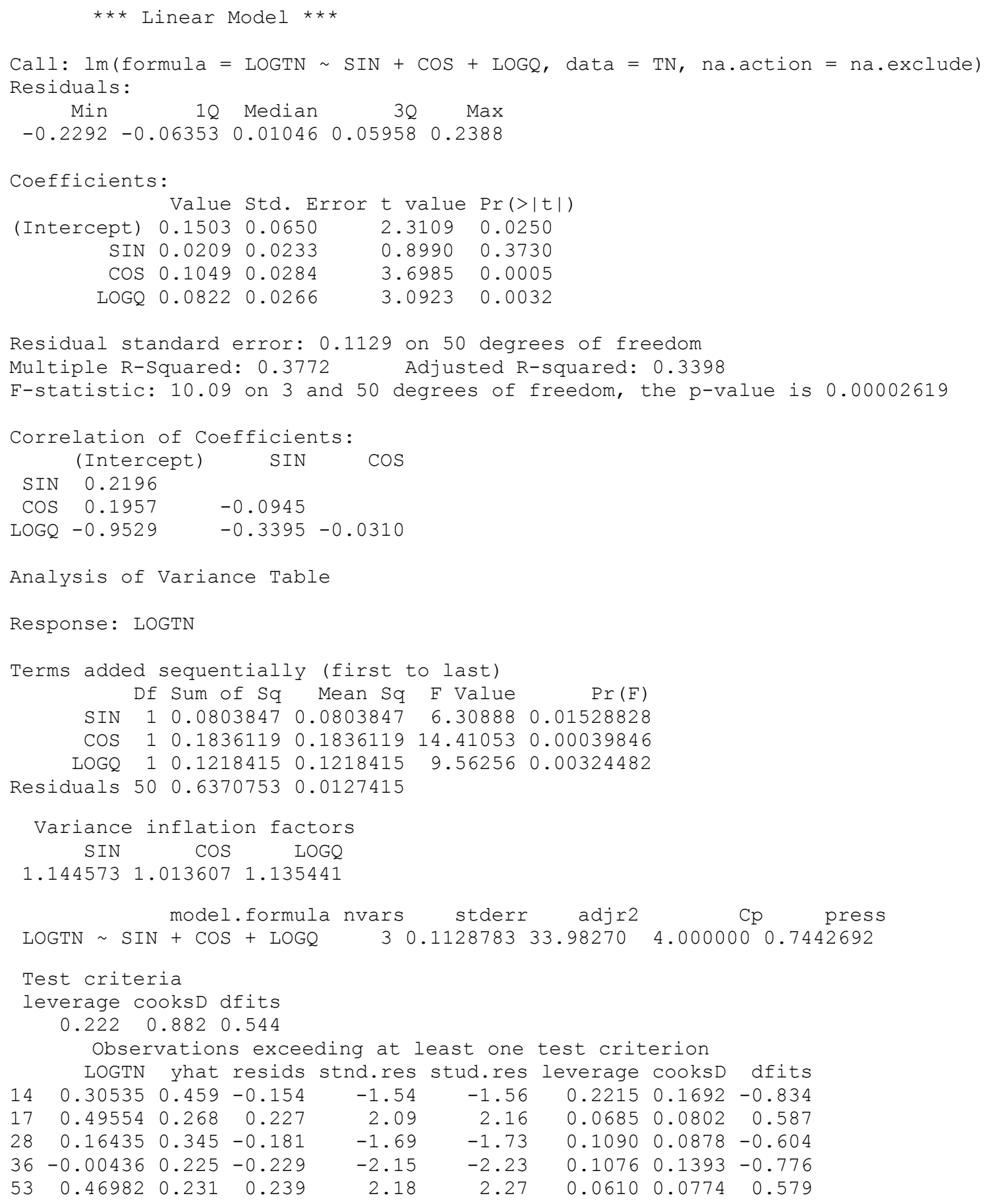

Figure 38. $\quad S+{ }^{\oplus}$ output of regression model development using season (SIN and COS) and streamflow (0) as explanatory variables for total nitrogen (TN) concentrations for the North Fork Ninnescah River upstream from Cheney Reservoir (site 07144780), south-central Kansas, 1999 through 2009. 

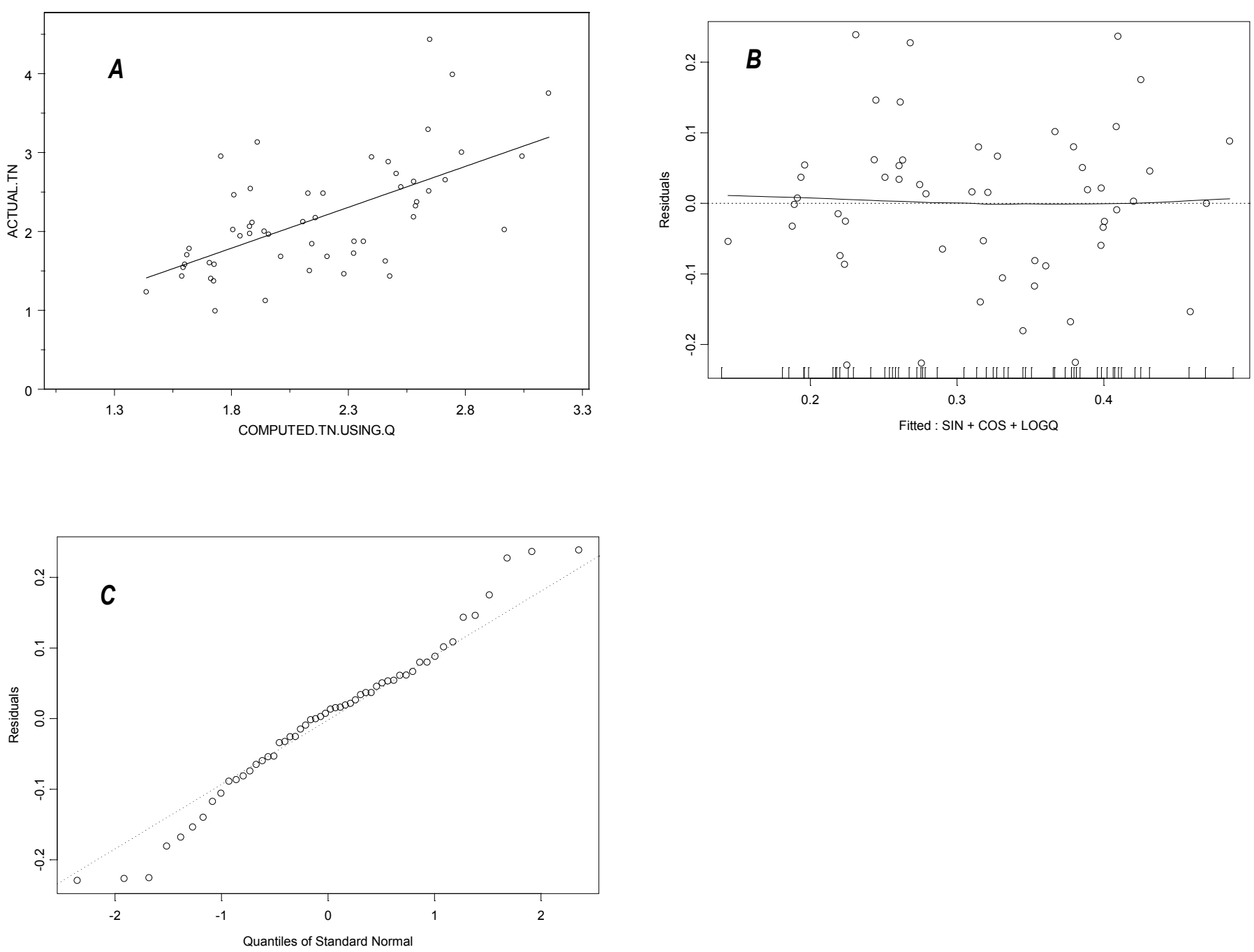

Figure 39. $S+{ }^{\circledR}$ output graphs from simple linear regression analysis using season (SIN and COS) and streamflow (0) as explanatory variables for total nitrogen (TN) concentrations showing $A$, computed versus actual TN concentrations; $B$, computed log-transformed TN concentrations versus regression residuals; and $C$, standard normal quantiles versus regression residuals for the North Fork Ninnescah River upstream from Cheney Reservoir (site 07144780), south-central Kansas, 1999 through 2009. 


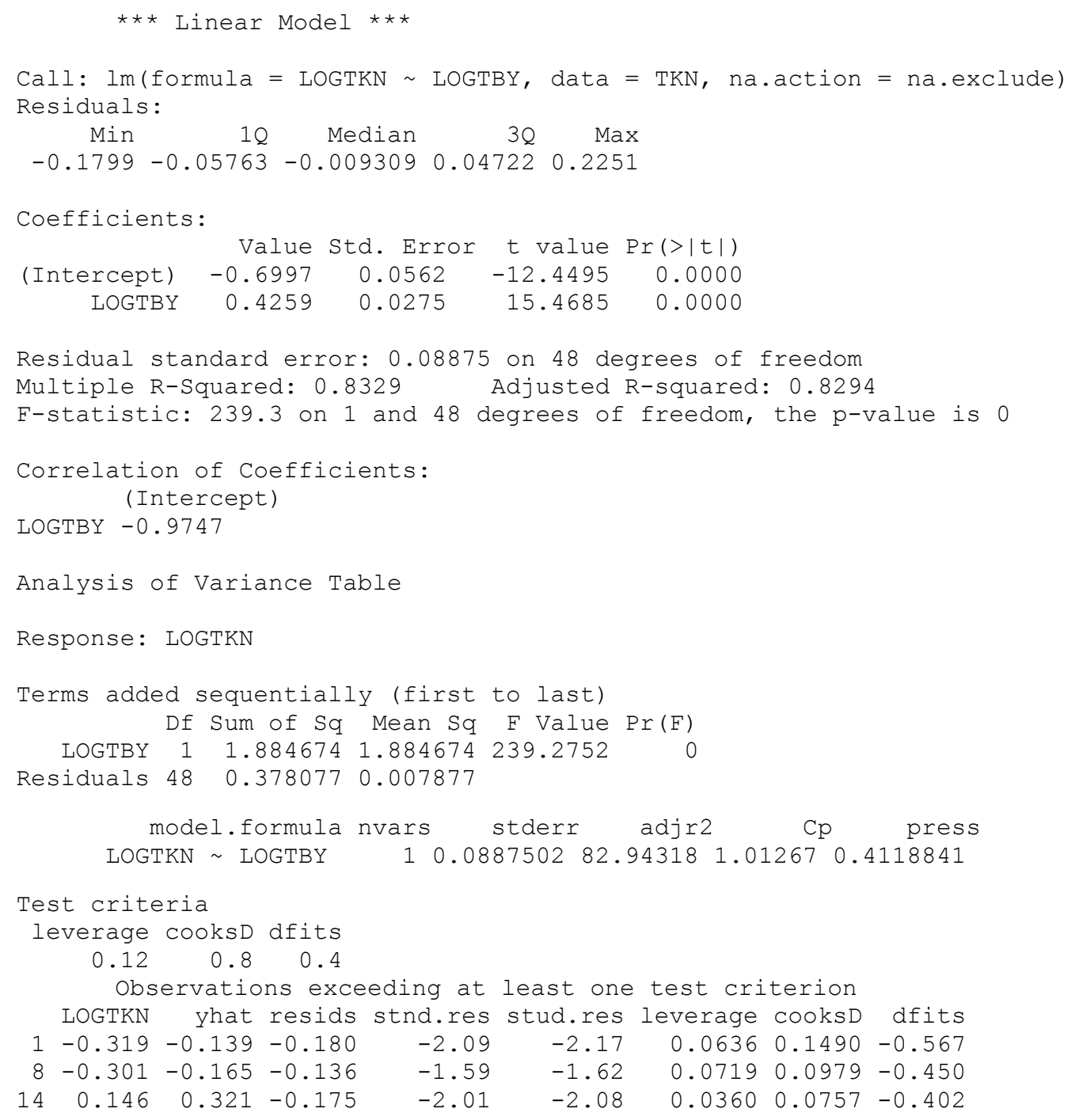

Figure 40. $\quad \mathrm{S}^{\circledR}{ }^{\circledR}$ output of regression model development using turbidity (TBY) as an explanatory variable for total Kjeldahl nitrogen (TKN) concentrations for the North Fork Ninnescah River upstream from Cheney Reservoir (site 07144780), south-central Kansas, 1999 through 2009. 

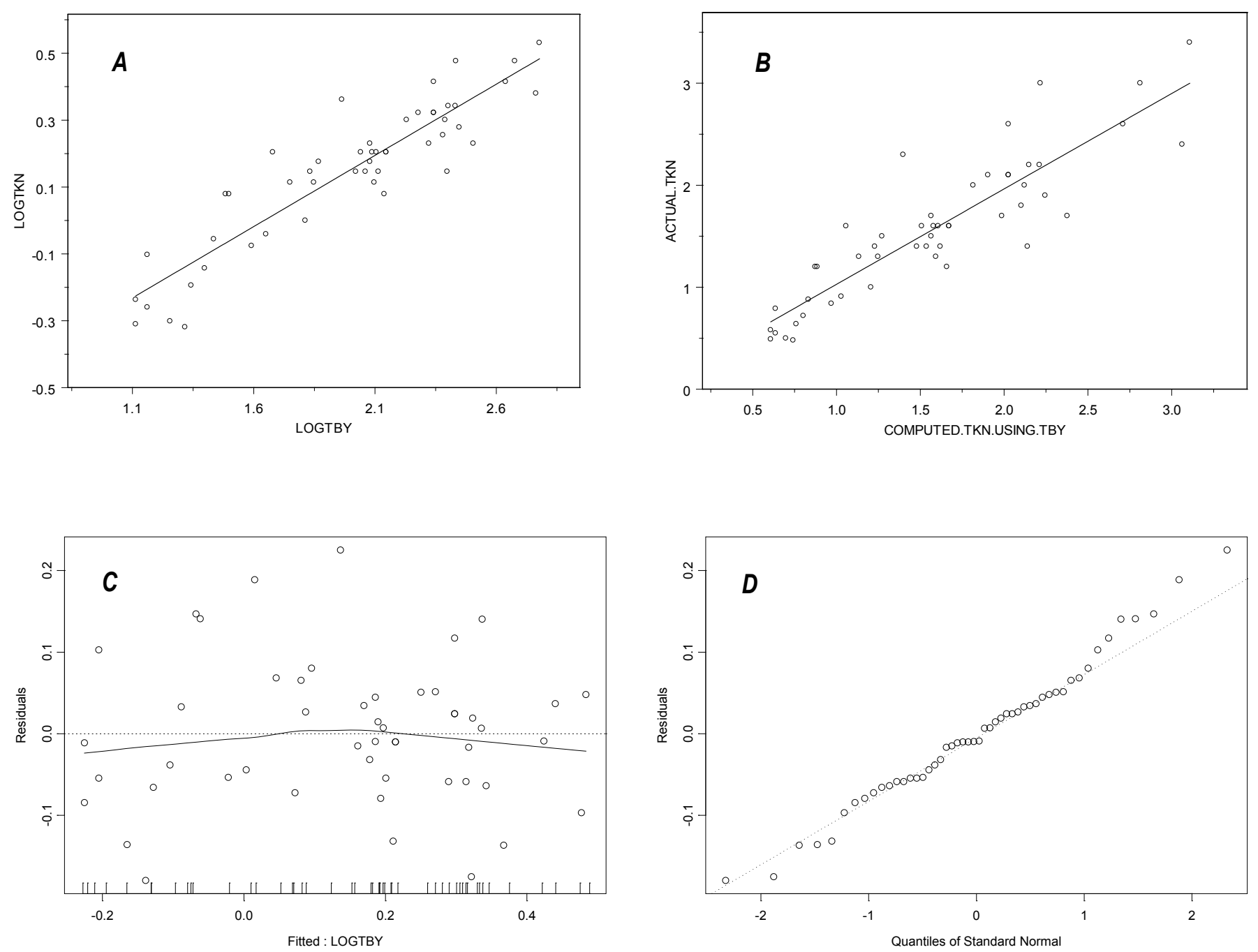

Figure 41. $\quad \mathrm{S}+{ }^{\oplus}$ output graphs from simple linear regression analysis showing $A$, log-transformed turbidity (TBY) versus log-transformed total Kjeldahl nitrogen (TKN) concentrations; $B$, computed versus actual TKN concentrations; $C$, computed log-transformed TKN concentrations versus regression residuals; and $D$, standard normal quantiles versus regression residuals for the North Fork Ninnescah River upstream from Cheney reservoir (site 07144780), south-central Kansas, 1999 through 2009. 


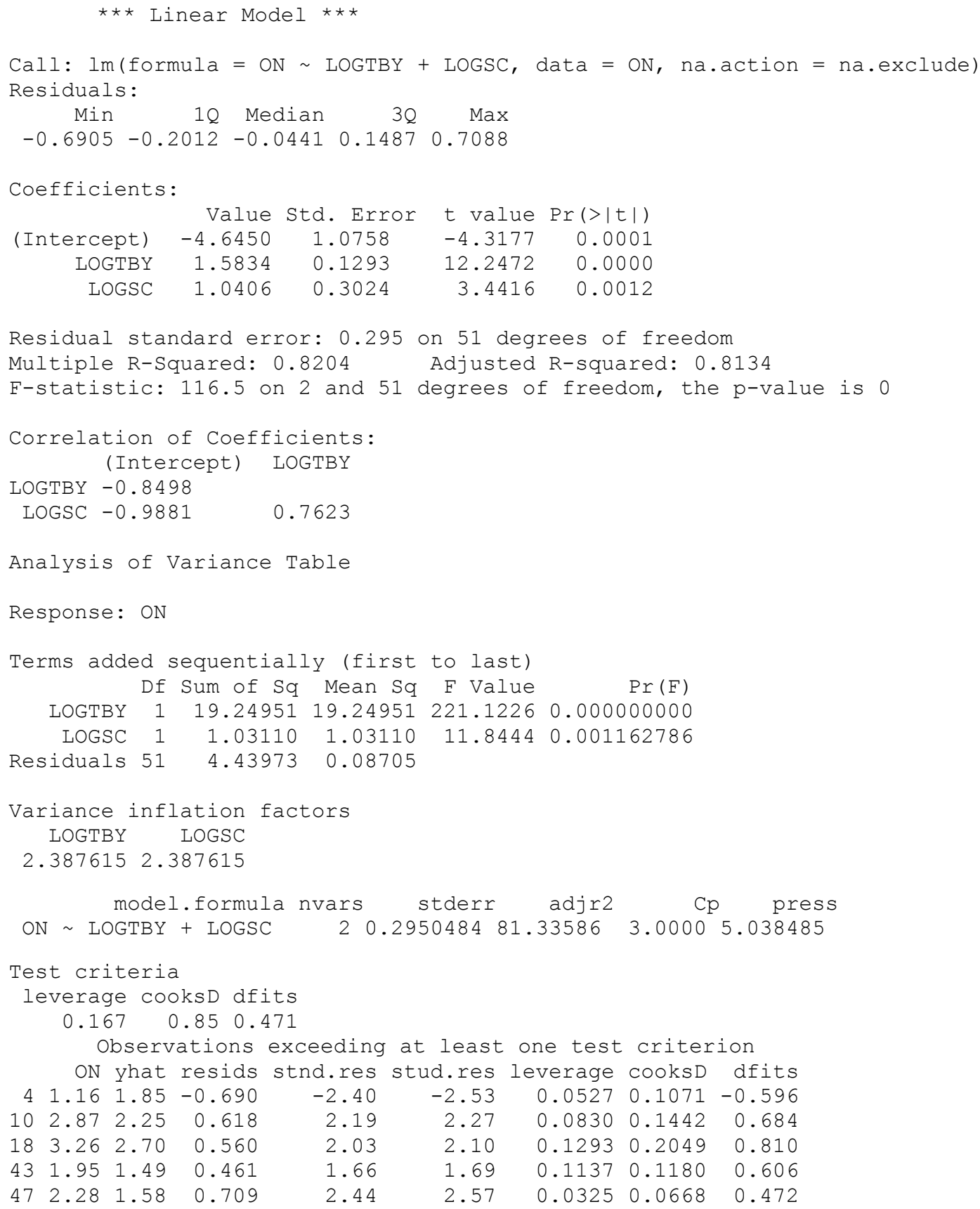

Figure 42. $\quad S+{ }^{\circledR}$ output of regression model development using turbidity (TBY) and specific conductance (SC) as explanatory variables for organic nitrogen (ON) concentrations for the North Fork Ninnescah River upstream from Cheney Reservoir (site 07144780), south-central Kansas, 1999 through 2009. 

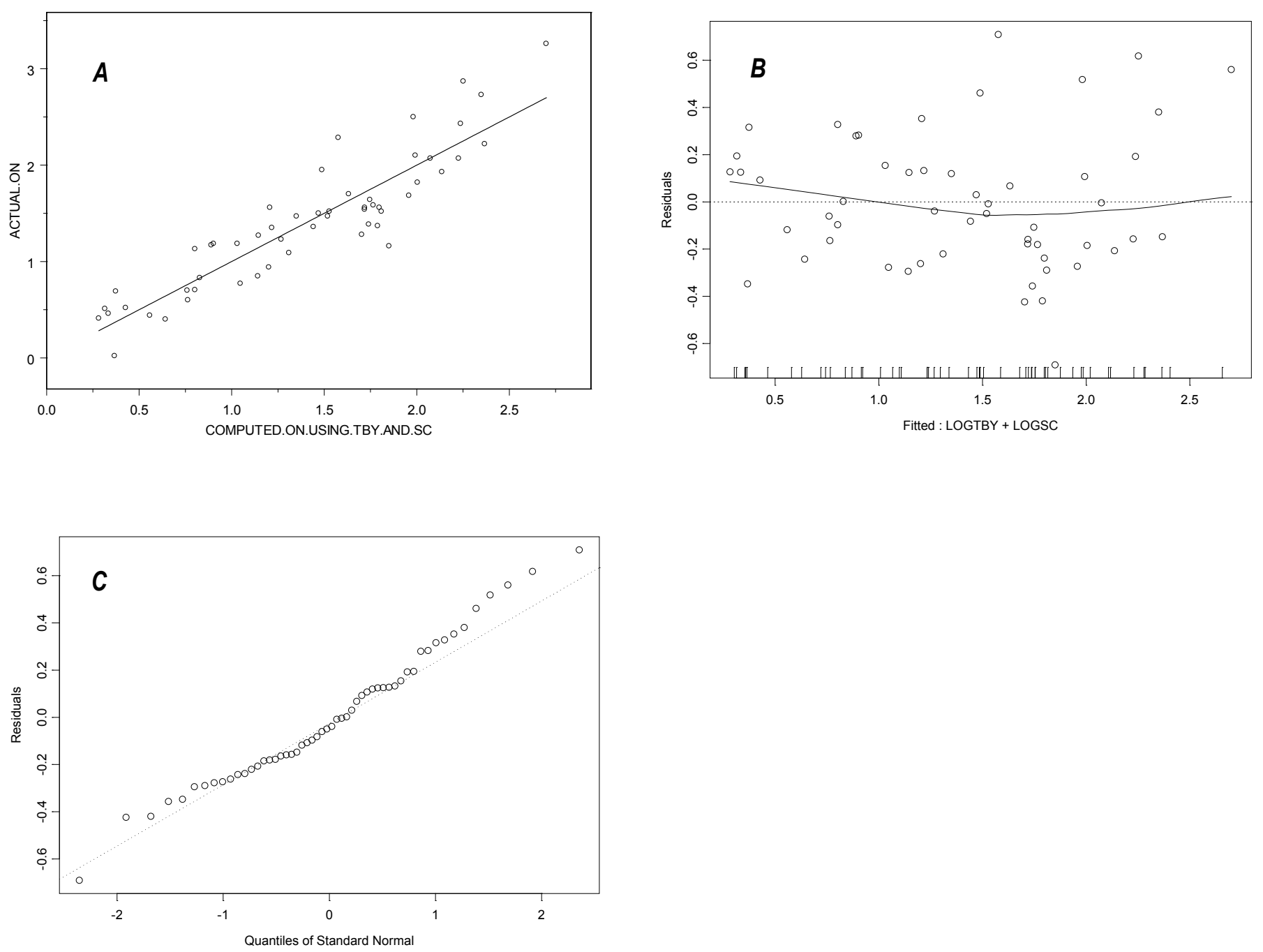

Figure 43. $\quad \mathrm{S}_{+}{ }^{\circledR}$ output graphs from simple linear regression analysis using turbidity (TBY) and specific conductance (SC) as explanatory variables for organic nitrogen (ON) concentrations showing $A$, computed versus actual ON concentrations; $B$, computed ON concentrations versus regression residuals; and $C$, standard normal quantiles versus regression residuals for the North Fork Ninnescah River upstream from Cheney Reservoir (site 07144780), south-central Kansas, 1999 through 2009. 


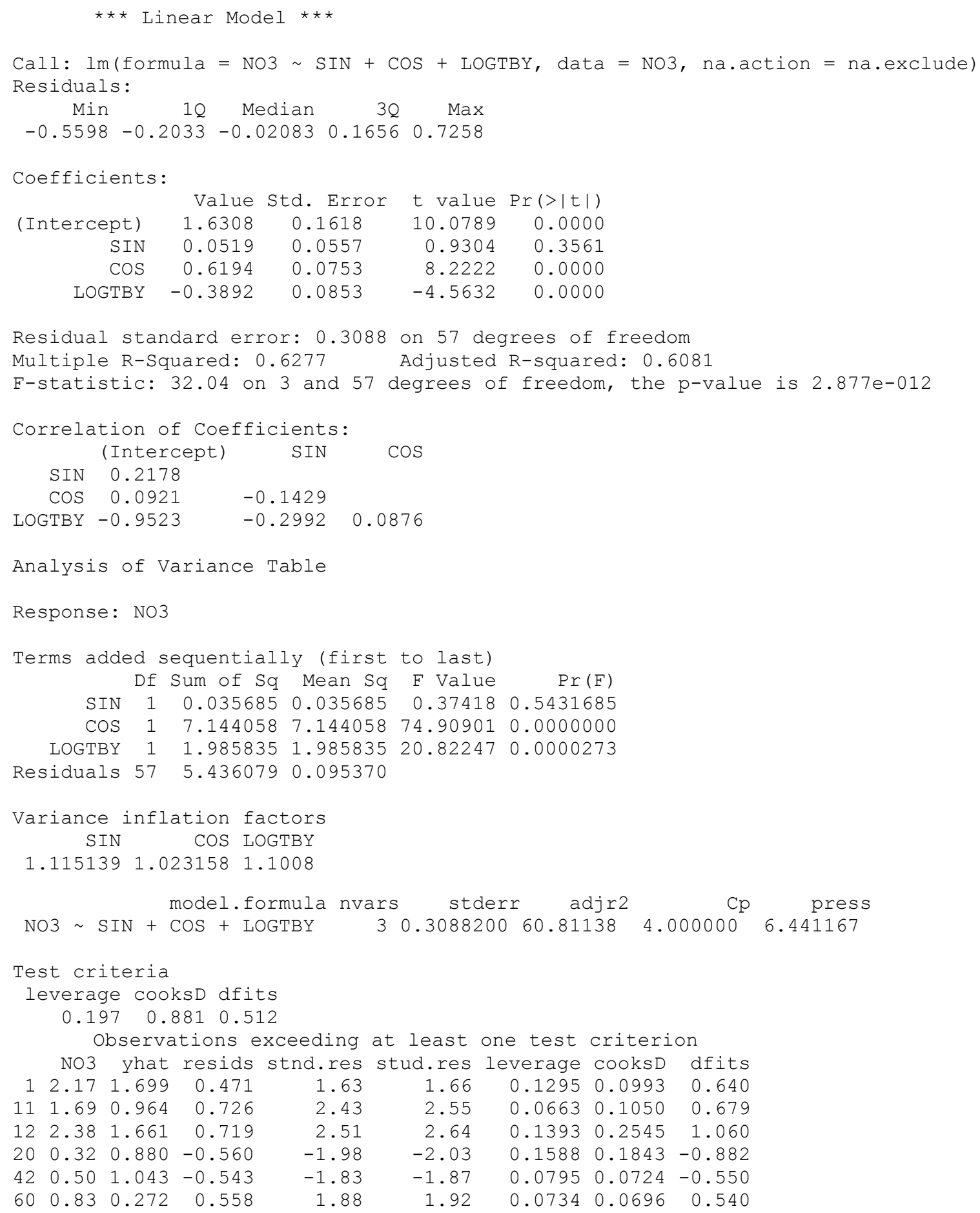

Figure 44. $S+{ }^{\circledR}$ output of regression model development using season (SIN and COS) and turbidity (TBY) as explanatory variables for nitrate (NO3) concentrations for the North Fork Ninnescah River upstream from Cheney Reservoir (site 07144780), south-central Kansas, 1999 through 2009. 

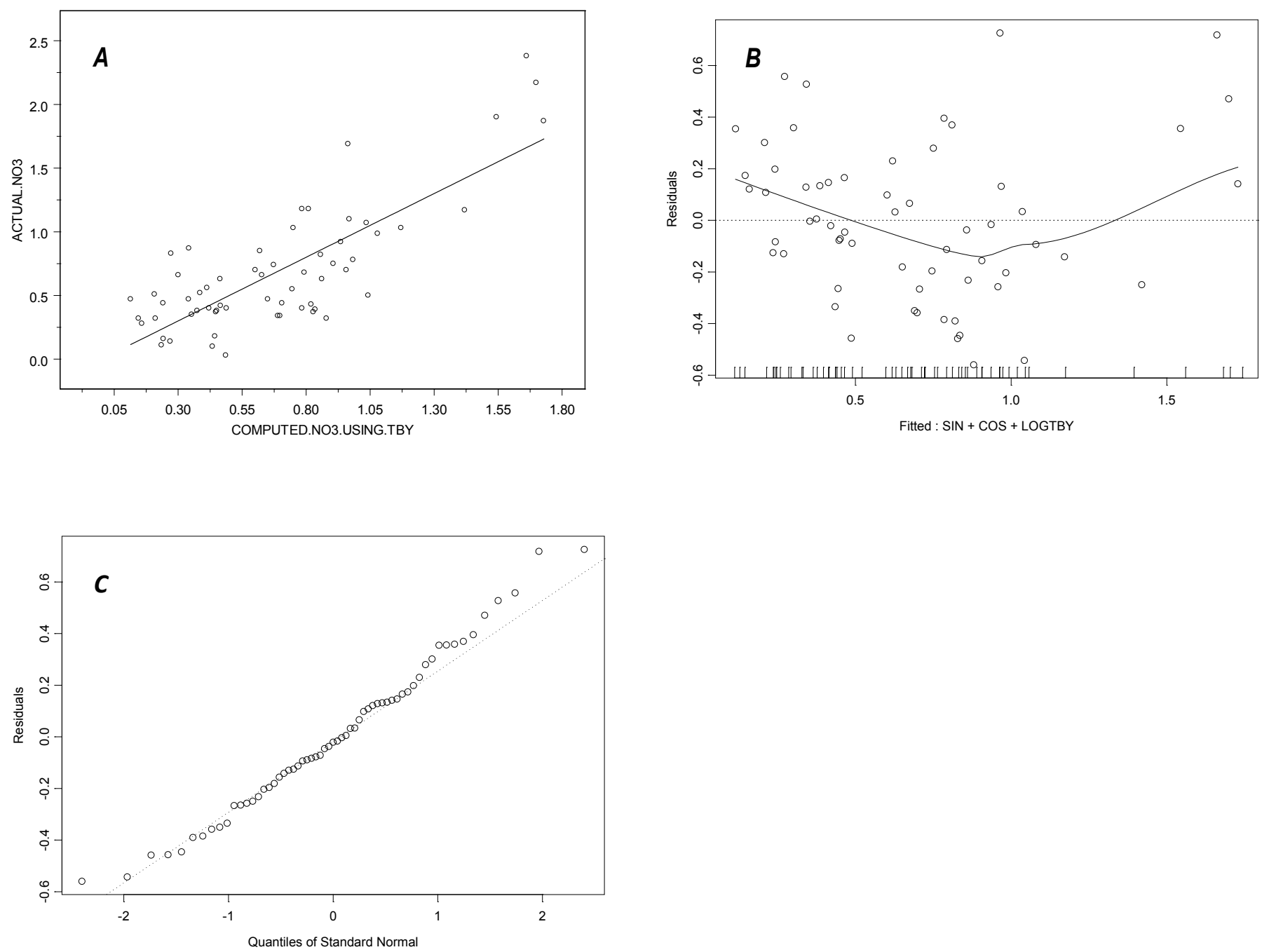

Figure 45. $\quad S+{ }^{\circledR}$ output graphs from simple linear regression analysis using season (SIN and COS) and turbidity (TBY) as explanatory variables for nitrate (NO3) concentrations showing $A$, computed versus actual N03 concentrations; $B$, computed N03 concentrations versus regression residuals; and $C$, standard normal quantiles versus regression residuals for the North Fork Ninnescah River upstream from Cheney Reservoir (site 07144780), south-central Kansas, 1999 through 2009. 


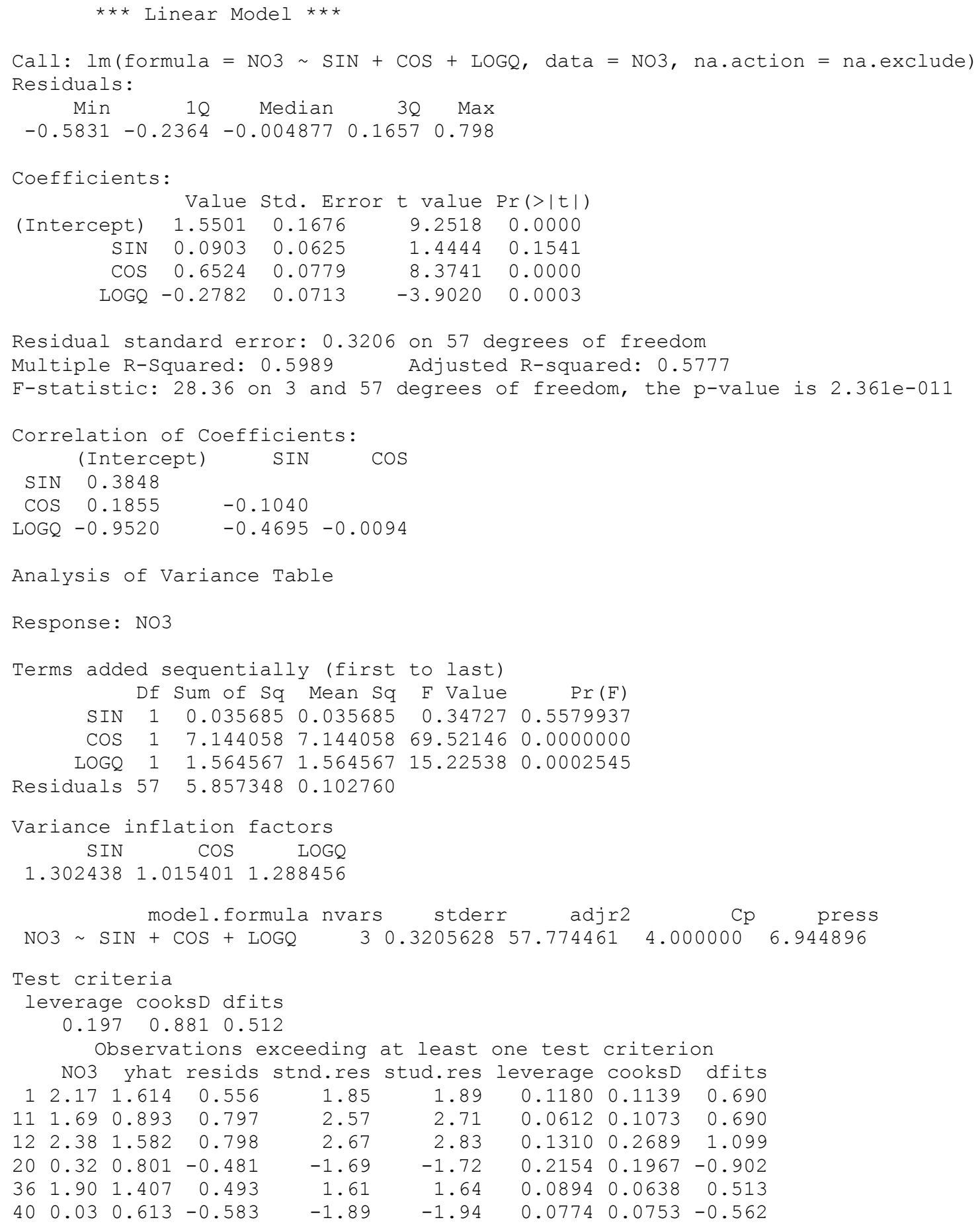

Figure 46. $\quad S+{ }^{\circledR}$ output of regression model development using season (SIN and COS) and streamflow (0) as explanatory variables for nitrate (NO3) concentrations for the North Fork Ninnescah River upstream from Cheney Reservoir (site 07144780), south-central Kansas, 1999 through 2009. 

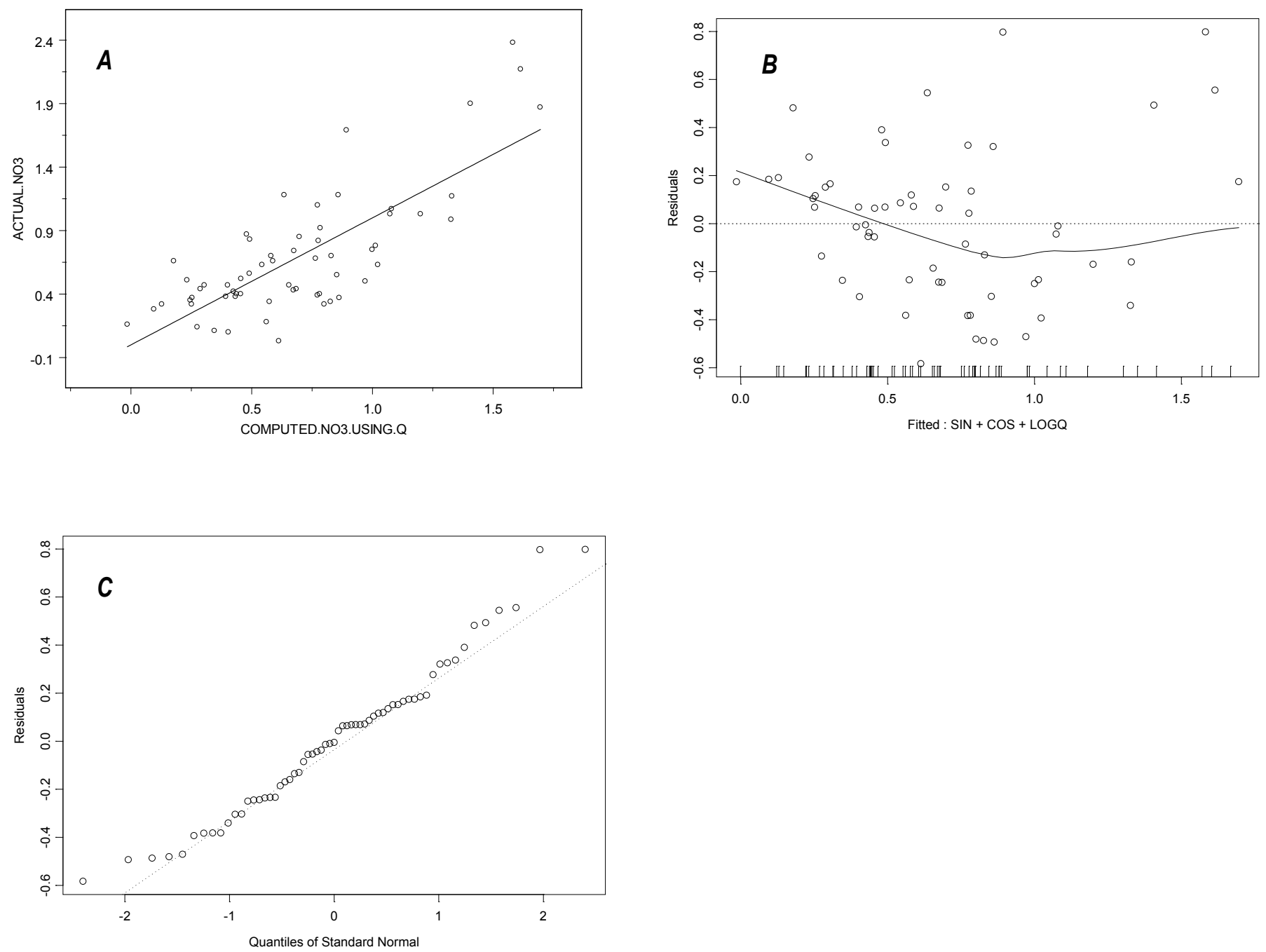

Figure 47. $S+{ }^{\circledR}$ output graphs from simple linear regression analysis using season (SIN and COS) and streamflow (0) as explanatory variables for nitrate (NO3) concentrations showing $A$, computed versus actual N03 concentrations; $B$, computed N03 concentrations versus regression residuals; and $C$, standard normal quantiles versus regression residuals for the North Fork Ninnescah River upstream from Cheney Reservoir (site 07144780), south-central Kansas, 1999 through 2009. 


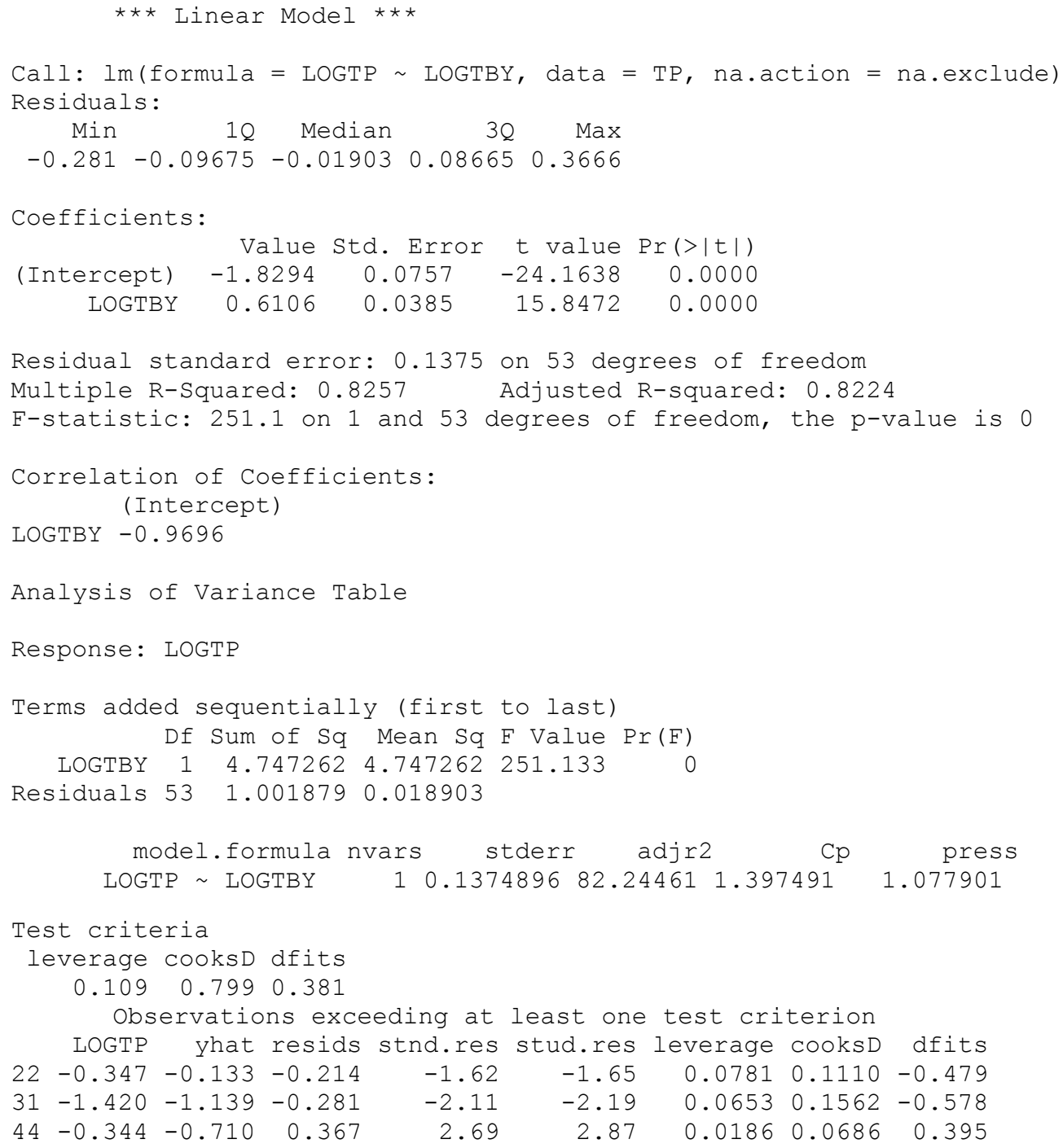

Figure 48. $\quad \mathrm{S}^{\circledR}{ }^{\circledR}$ output of regression model development using turbidity (TBY) as an explanatory variable for total phosphorus (TP) concentrations for the North Fork Ninnescah River upstream from Cheney Reservoir (site 07144780), south-central Kansas, 1999 through 2009. 

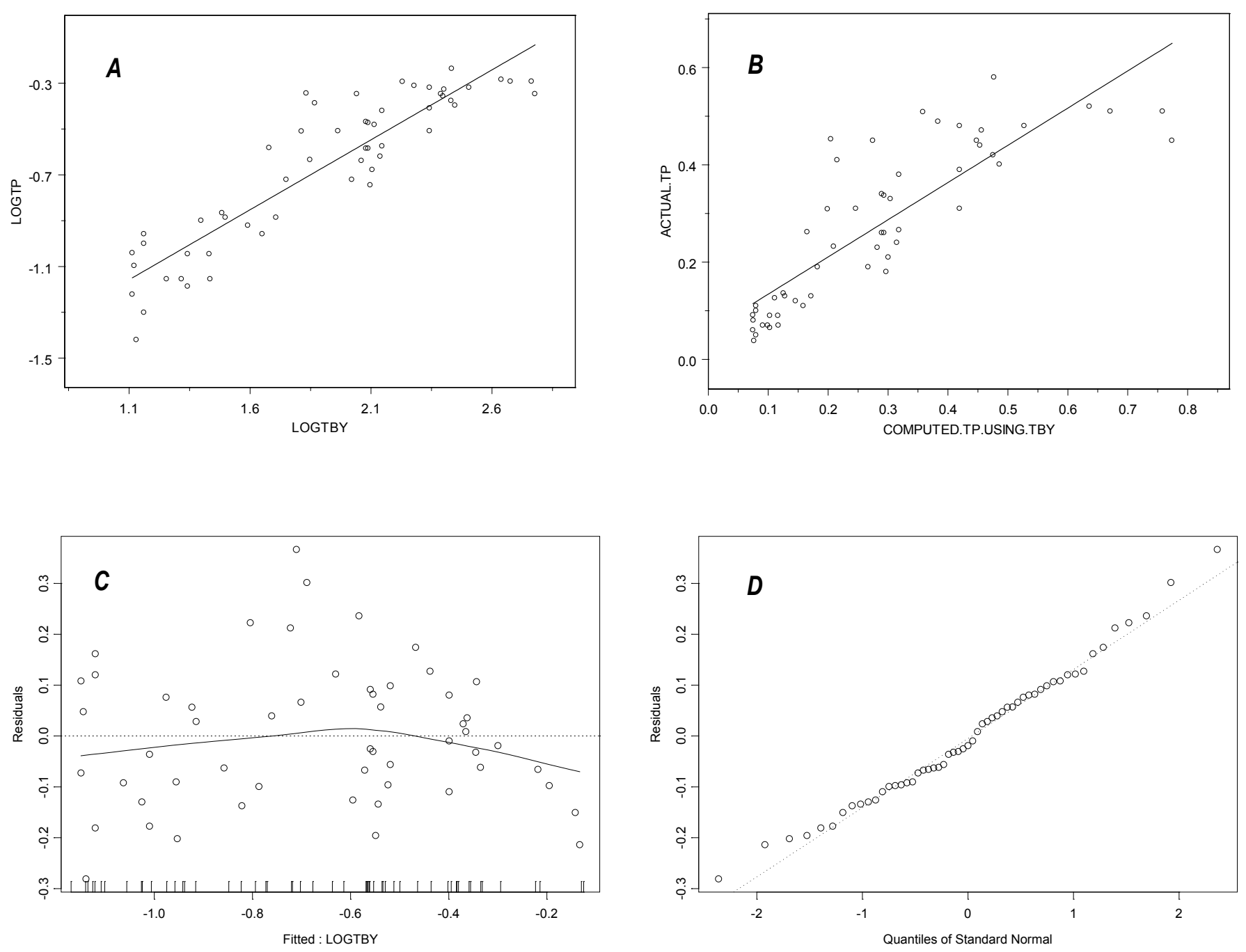

Figure 49. $S+{ }^{\oplus}$ output graphs from simple linear regression analysis showing $A$, log-transformed turbidity (TBY) versus log-transformed total phosphorus (TP) concentrations; $B$, computed versus actual TP concentrations; $C$, computed log-transformed TP concentrations versus regression residuals; and $D$, standard normal quantiles versus regression residuals for the North Fork Ninnescah River upstream from Cheney Reservoir (site 07144780), south-central Kansas, 1999 through 2009. 


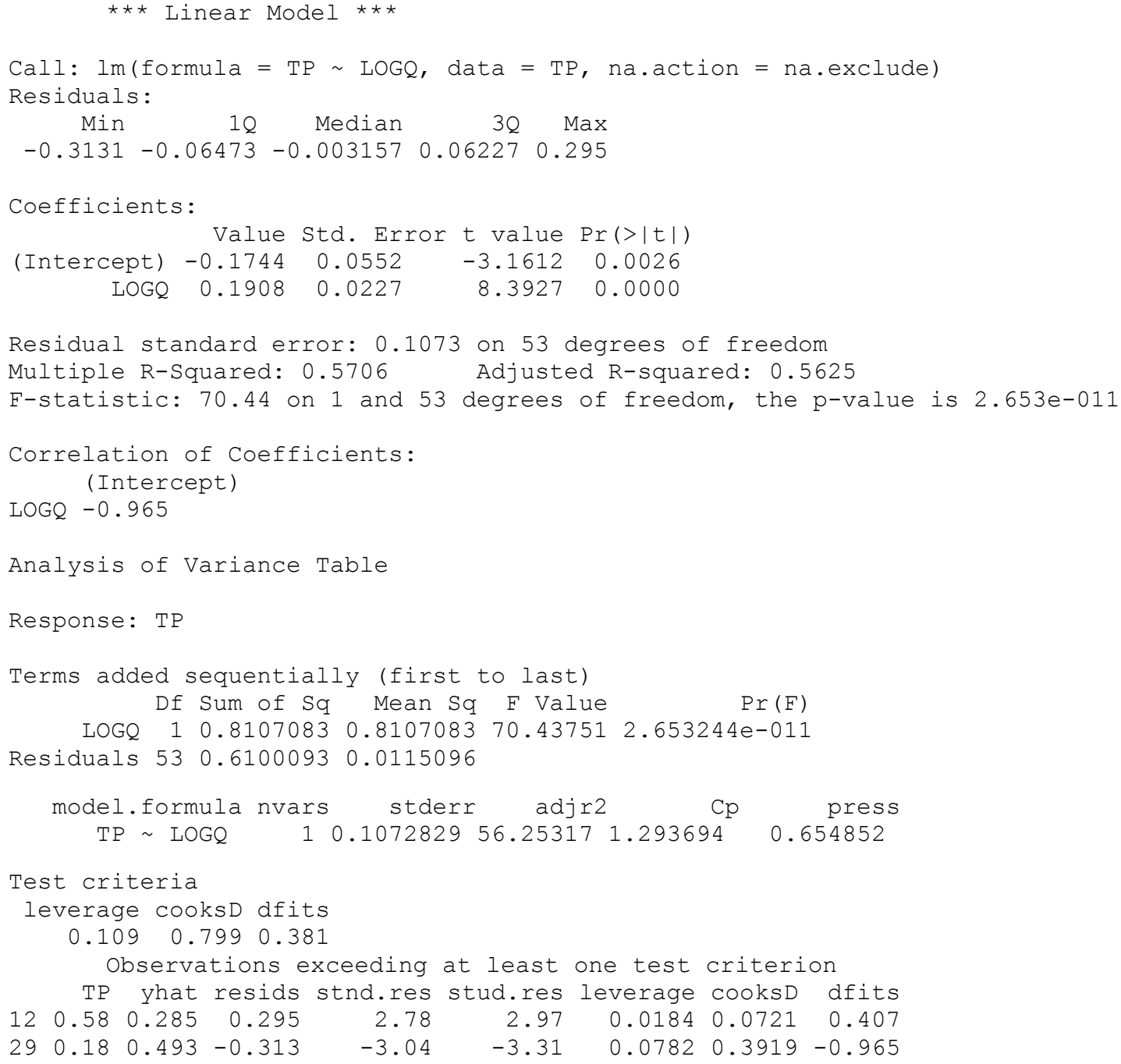

Figure 50. $\quad S+{ }^{\circledR}$ output of regression model development using streamflow (0) as an explanatory variable for total phosphorus (TP) concentrations for the North Fork Ninnescah River upstream from Cheney Reservoir (site 07144780), south-central Kansas, 1999 through 2009. 

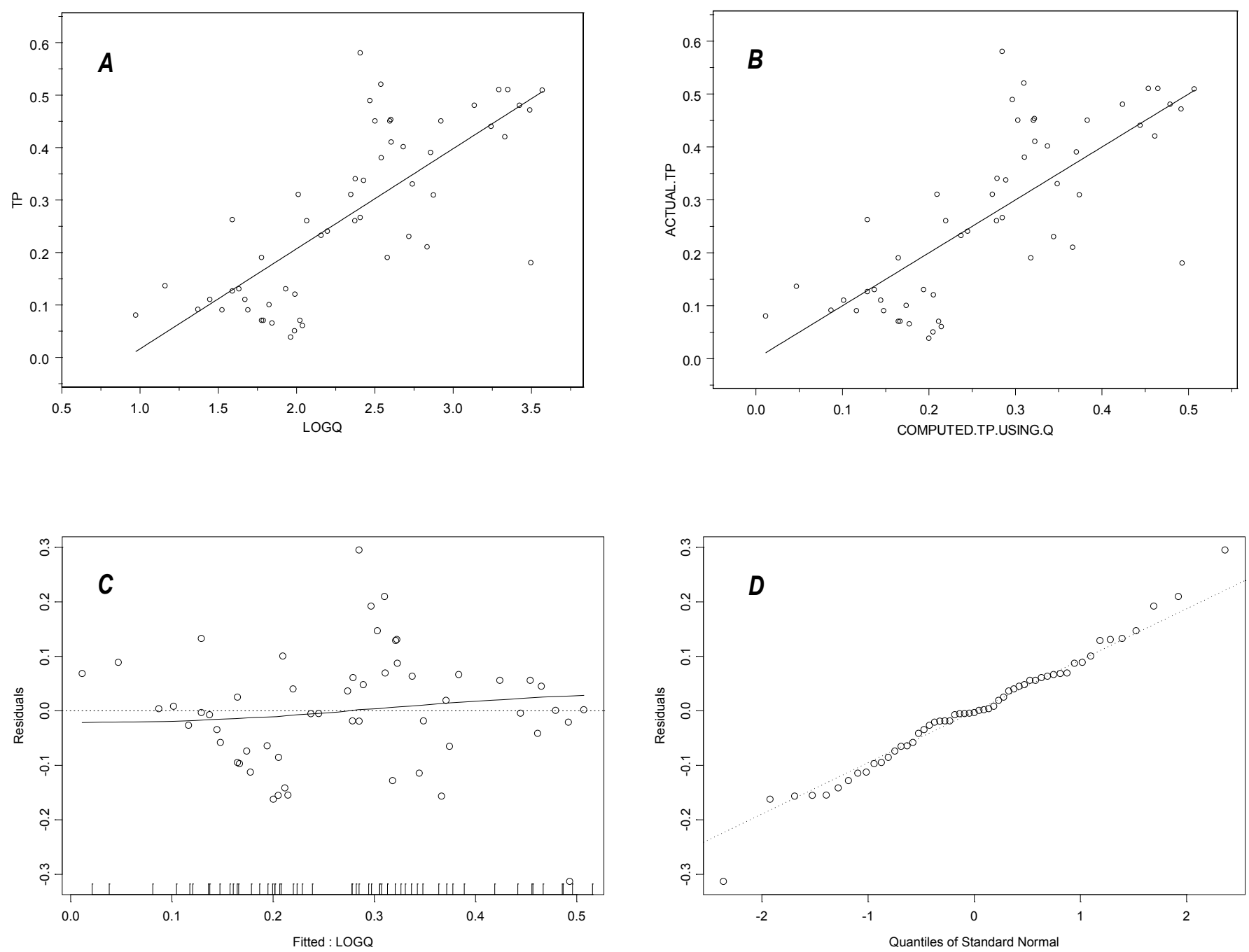

Figure 51. $S+{ }^{\oplus}$ output graphs from simple linear regression analysis showing $A$, log-transformed streamflow $(0)$ versus total phosphorus (TP) concentrations; $B$, computed versus actual TP concentrations; $C$, computed TP concentrations versus regression residuals; and $D$, standard normal quantiles versus regression residuals for the North Fork Ninnescah River upstream from Cheney Reservoir (site 07144780), south-central Kansas, 1999 through 2009. 


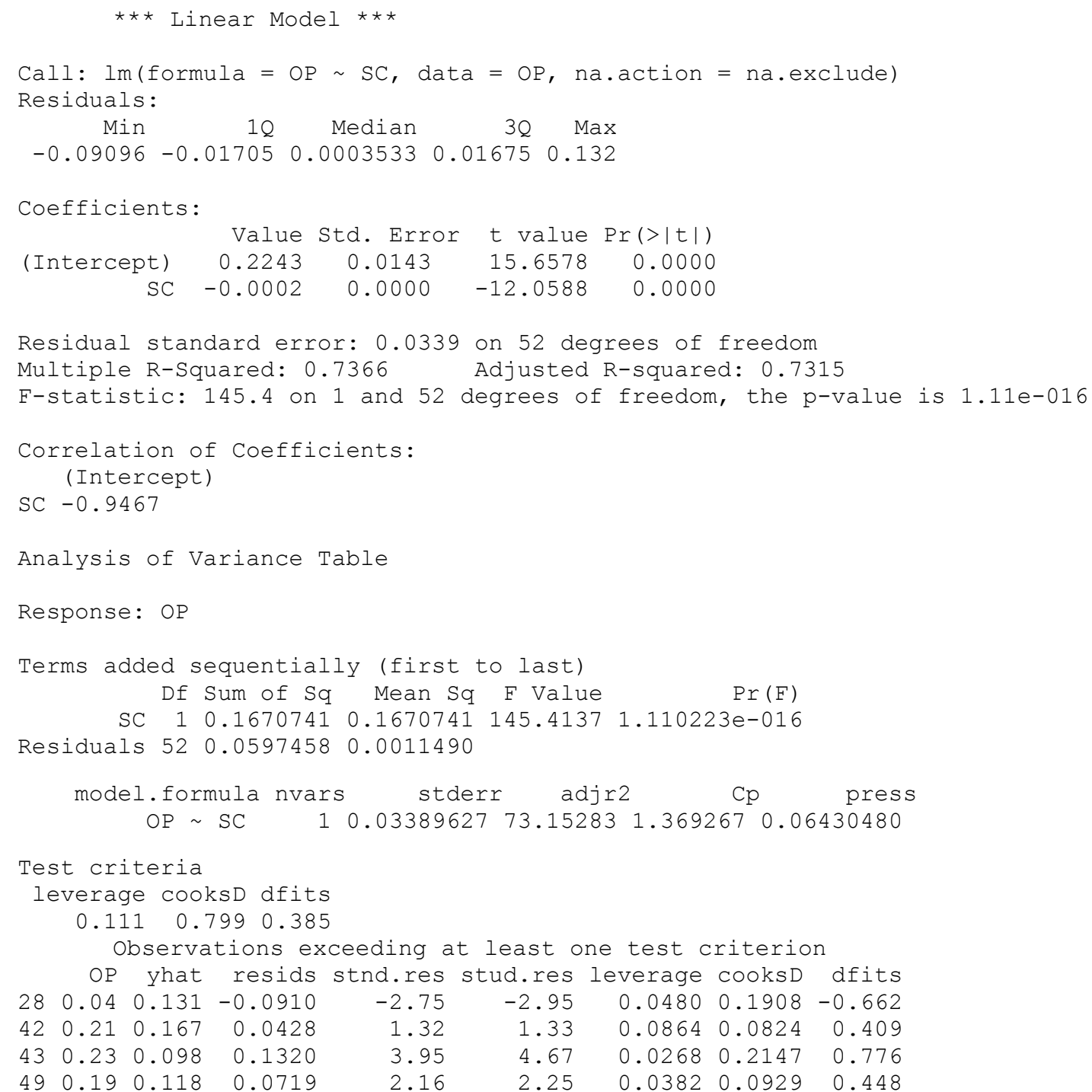

Figure 52. S+ ${ }^{\circledR}$ output of regression model development using specific conductance (SC) as an explanatory variable for orthophosphate (OP) concentrations for the North Fork Ninnescah River upstream from Cheney Reservoir (site 07144780), south-central Kansas, 1999 through 2009. 

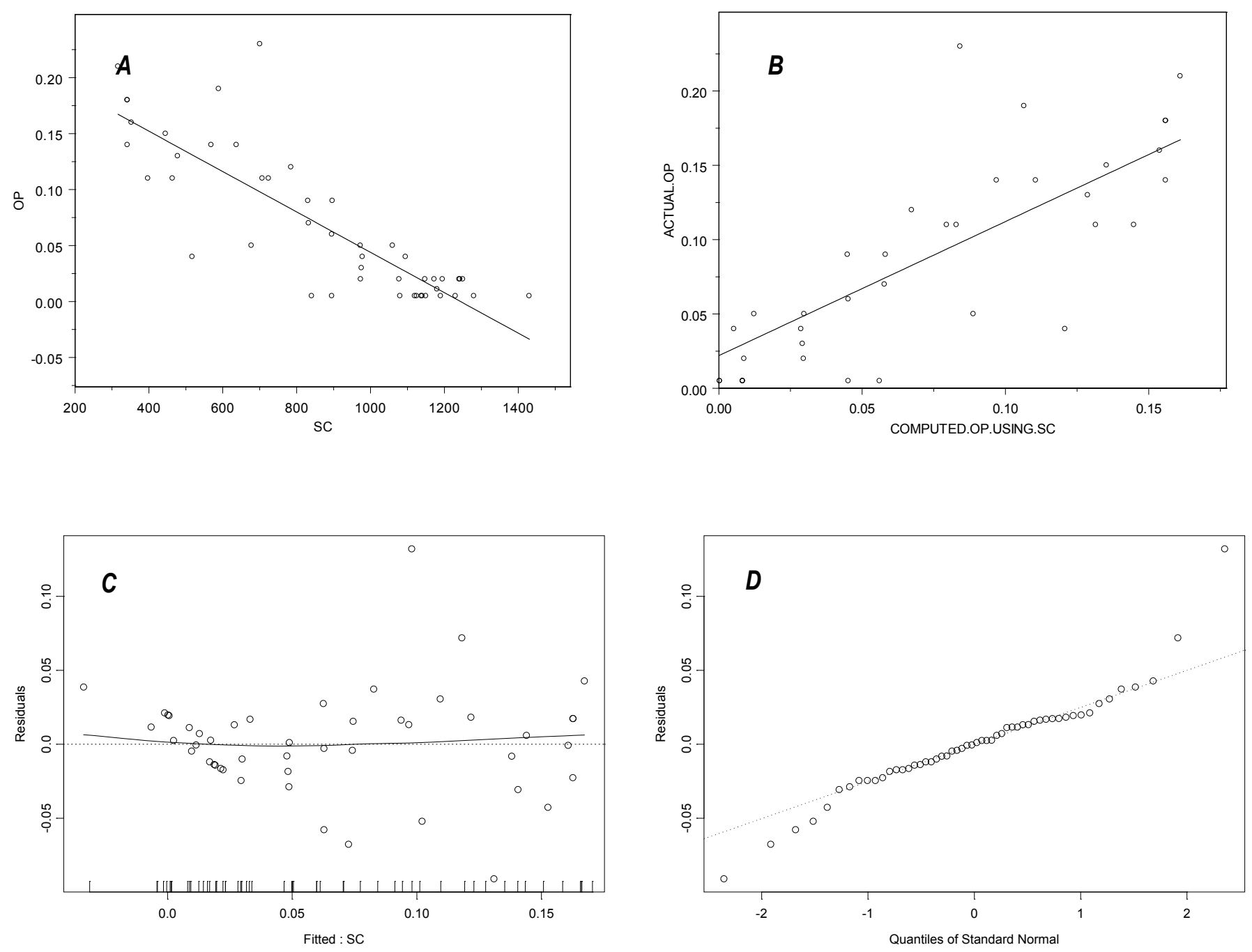

Figure 53. $S+{ }^{\circledR}$ output graphs from simple linear regression analysis showing $A$, specific conductance (SC) versus orthophosphate (OP) concentrations; $B$, computed versus actual OP concentrations; $C$, computed OP concentrations versus regression residuals; and $D$, standard normal quantiles versus regression residuals for the North Fork Ninnescah River upstream from Cheney Reservoir (site 07144780), south-central Kansas, 1999 through 2009. 


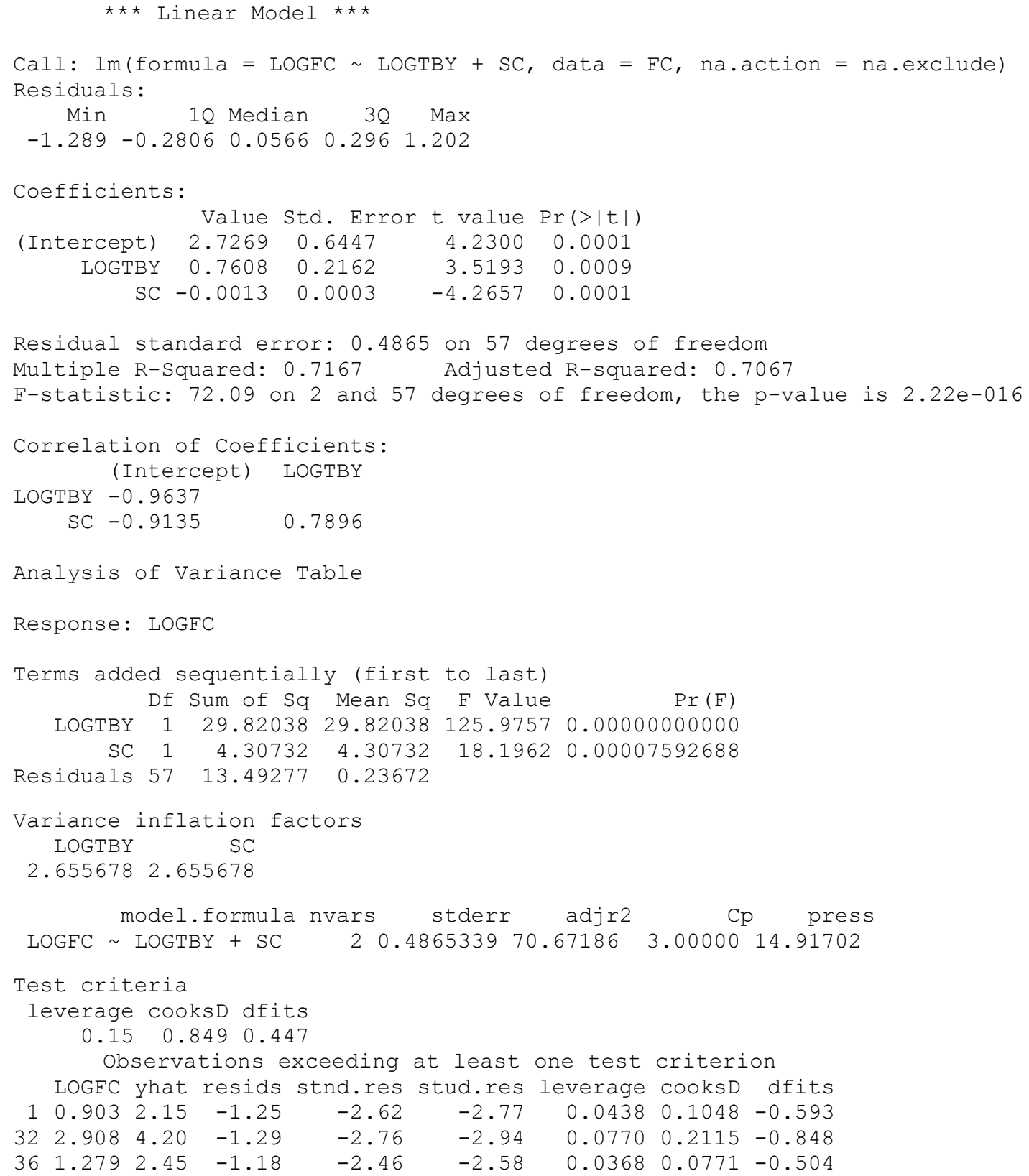

Figure 54. S $+^{\circledR}$ output of regression model development using turbidity (TBY) and specific conductance (SC) as explanatory variables for fecal coliform bacteria (FC) densities for the North Fork Ninnescah River upstream from Cheney Reservoir (site 07144780), south-central Kansas, 1999 through 2009. 

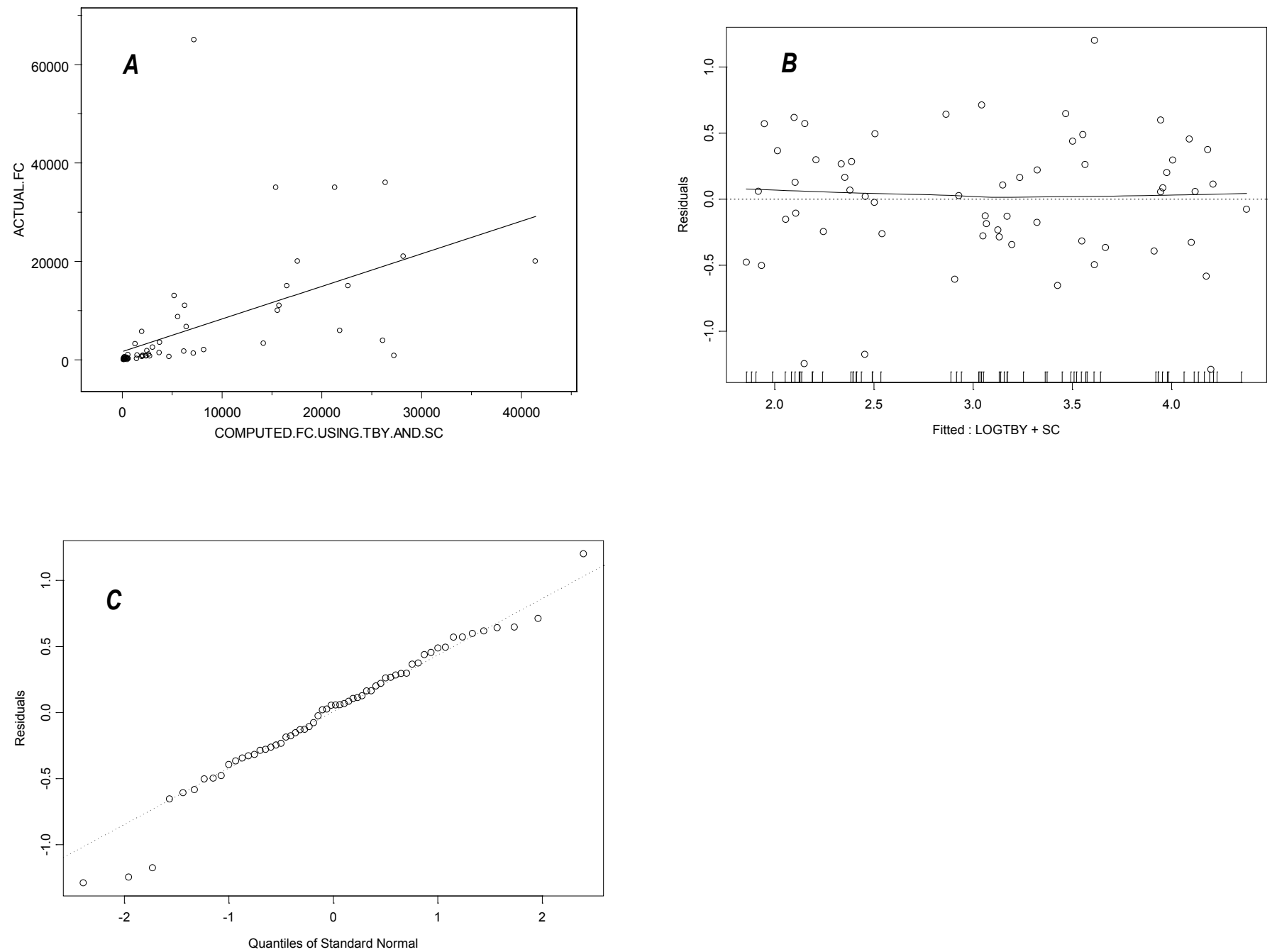

Figure 55. $S+{ }^{\circledR}$ output graphs from simple linear regression analysis using turbidity (TBY) and specific conductance (SC) as explanatory variables for fecal coliform (FC) densities showing $A$, computed versus actual FC densities; $B$, computed log-transformed FC densities versus regression residuals; and $C$, standard normal quantiles versus regression residuals for the North Fork Ninnescah River upstream from Cheney Reservoir (site 07144780), south-central Kansas, 1999 through 2009. 


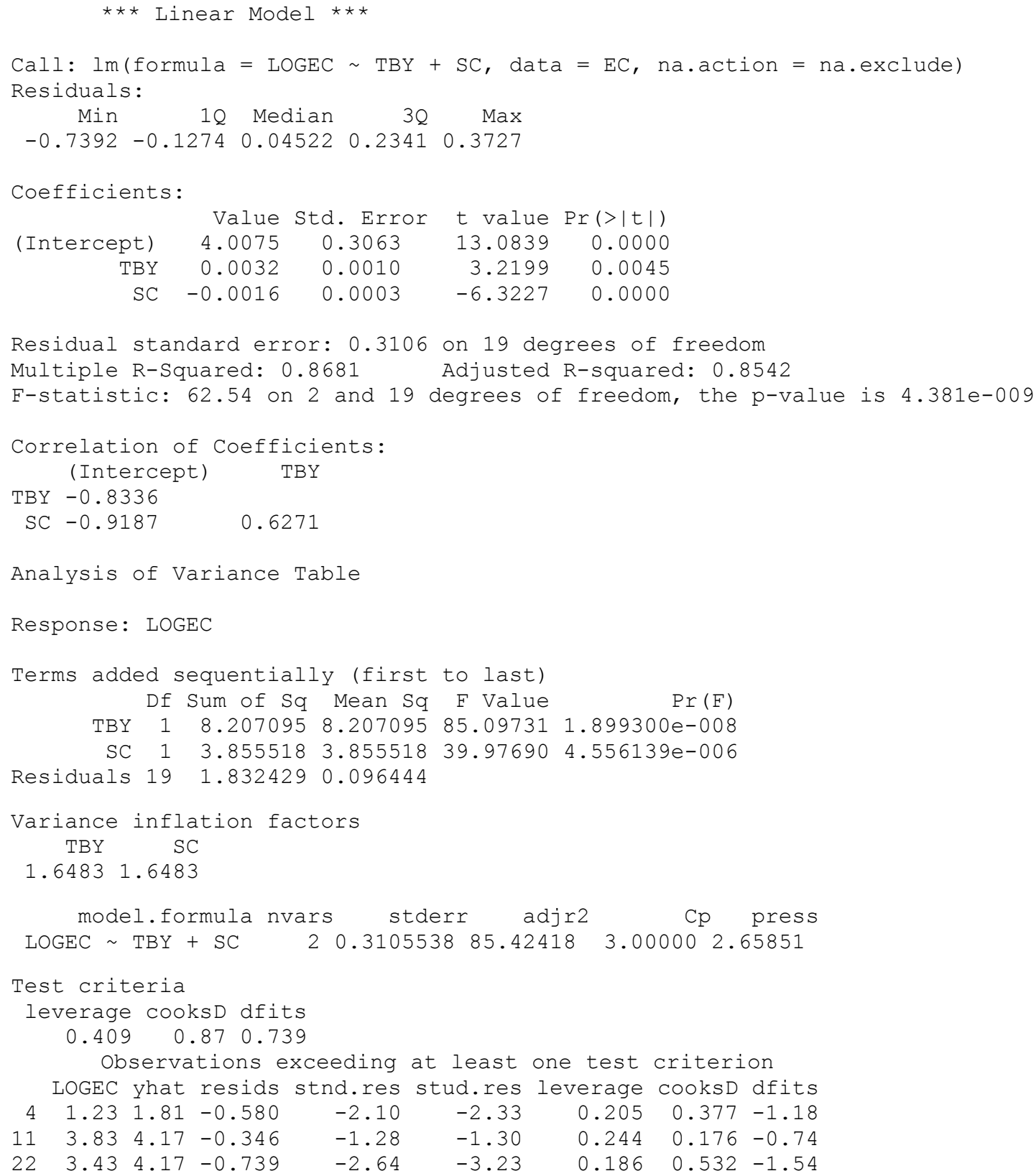

Figure 56. S $+^{\circledR}$ output of regression model development using turbidity (TBY) and specific conductance (SC) as explanatory variables for Escherichia coli bacteria (EC) densities for the North Fork Ninnescah River upstream from Cheney Reservoir (site 07144780), south-central Kansas, 1999 through 2009. 

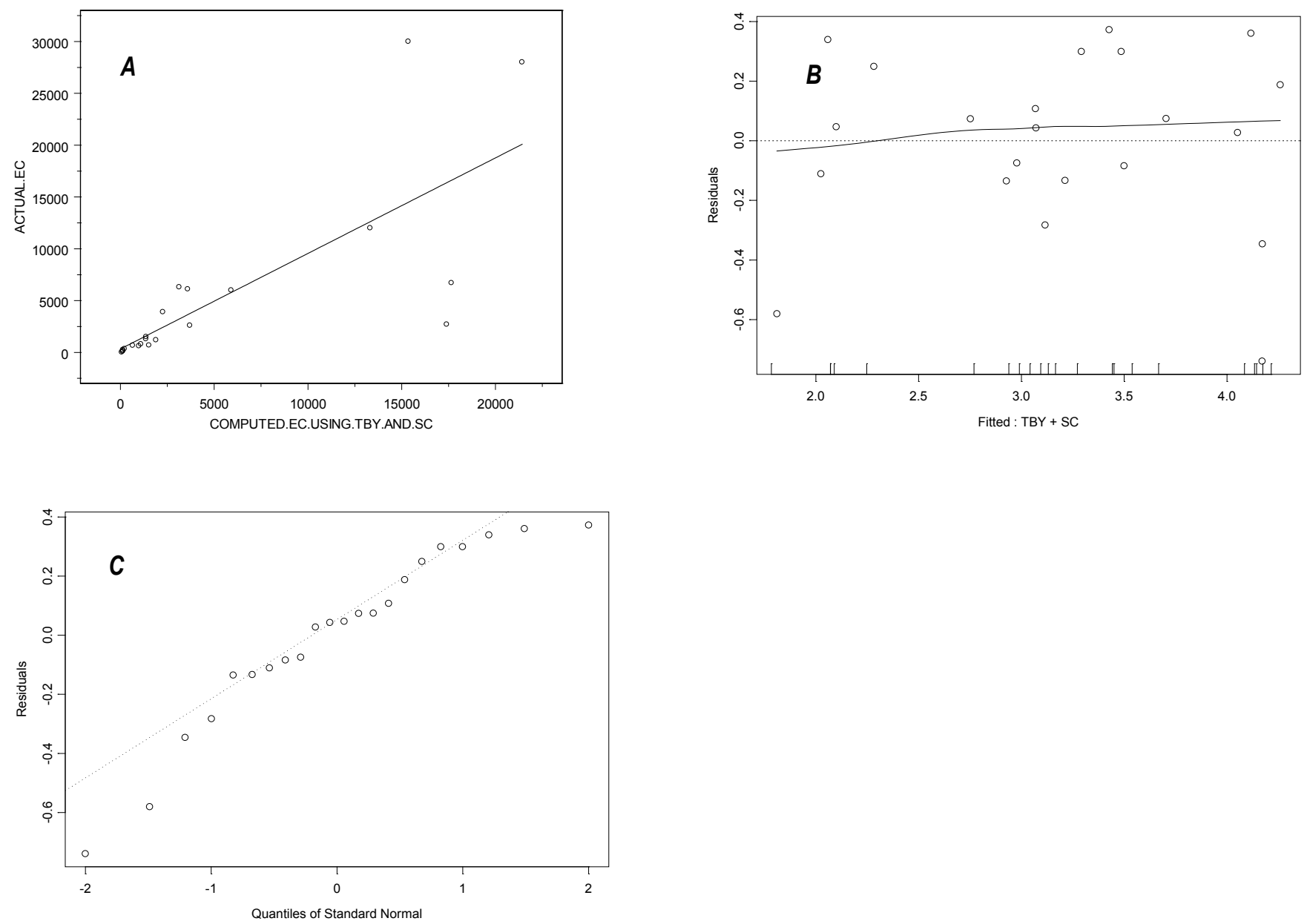

Figure 57. $S+{ }^{\circledR}$ output graphs from simple linear regression analysis using turbidity (TBY) and specific conductance (SC) as explanatory variables for Escherichia coli bacteria (EC) densities showing $A$, computed versus actual EC densities; $B$, computed logtransformed EC densities versus regression residuals; and $C$, standard normal quantiles versus regression residuals for the North Fork Ninnescah River upstream from Cheney Reservoir (site 07144780), south-central Kansas, 1999 through 2009. 


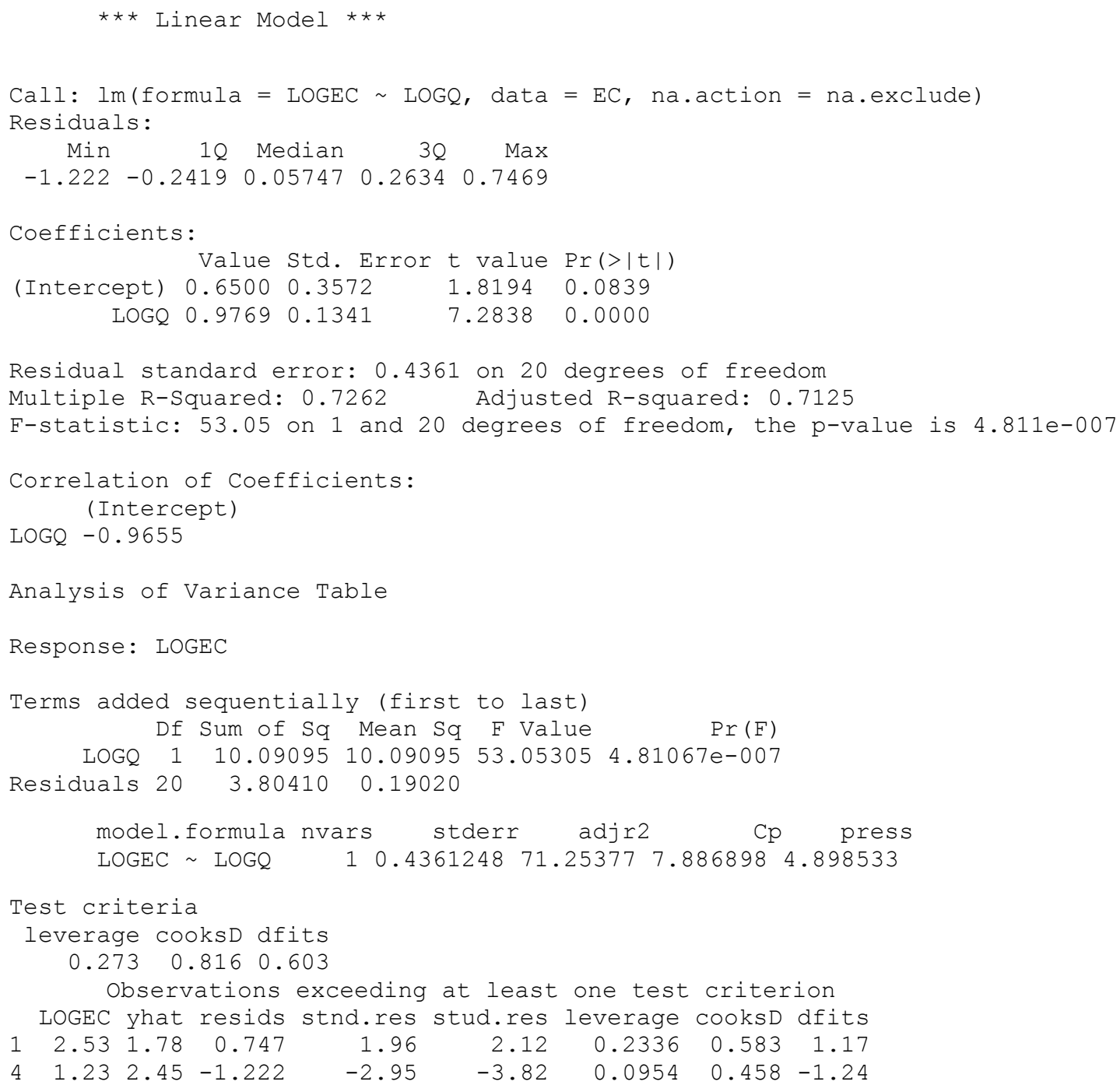

Figure 58. $\quad S+{ }^{\circledR}$ output of regression model development using streamflow $(0)$ as an explanatory variable for Escherichia coli bacteria (EC) densities for the North Fork Ninnescah River upstream from Cheney Reservoir (site 07144780), south-central Kansas, 1999 through 2009. 

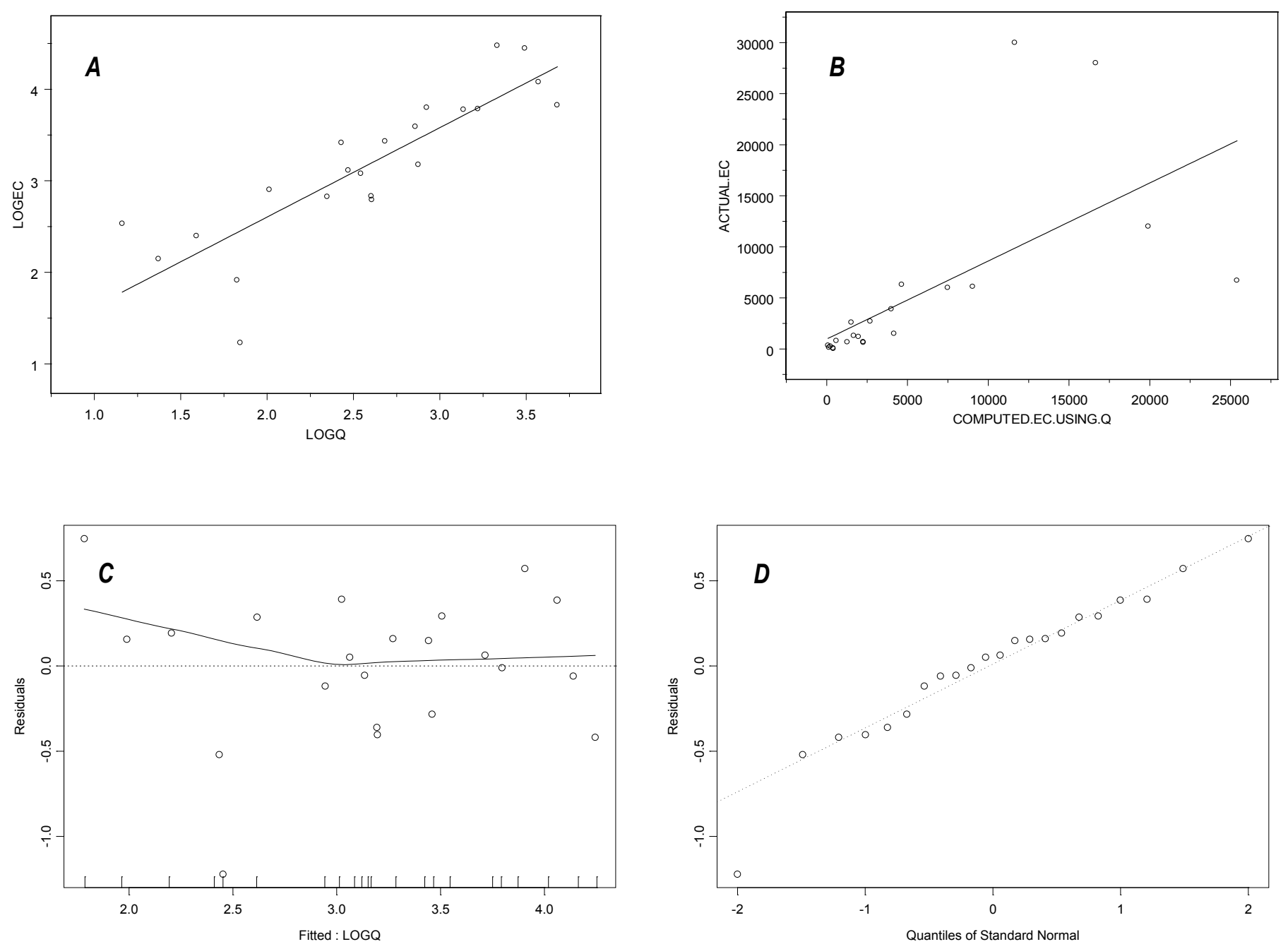

Figure 59. $\quad S+{ }^{\circledR}$ output graphs from simple linear regression analysis showing $A$, log-transformed streamflow $(0)$ versus logtransformed Escherichia coli bacteria (EC) densities; $B$, computed versus actual EC densities; $C$, computed log-transformed EC densities versus regression residuals; and $D$, standard normal quantiles versus regression residuals for the North Fork Ninnescah River upstream from Cheney Reservoir (site 07144780), south-central Kansas, 1999 through 2009. 


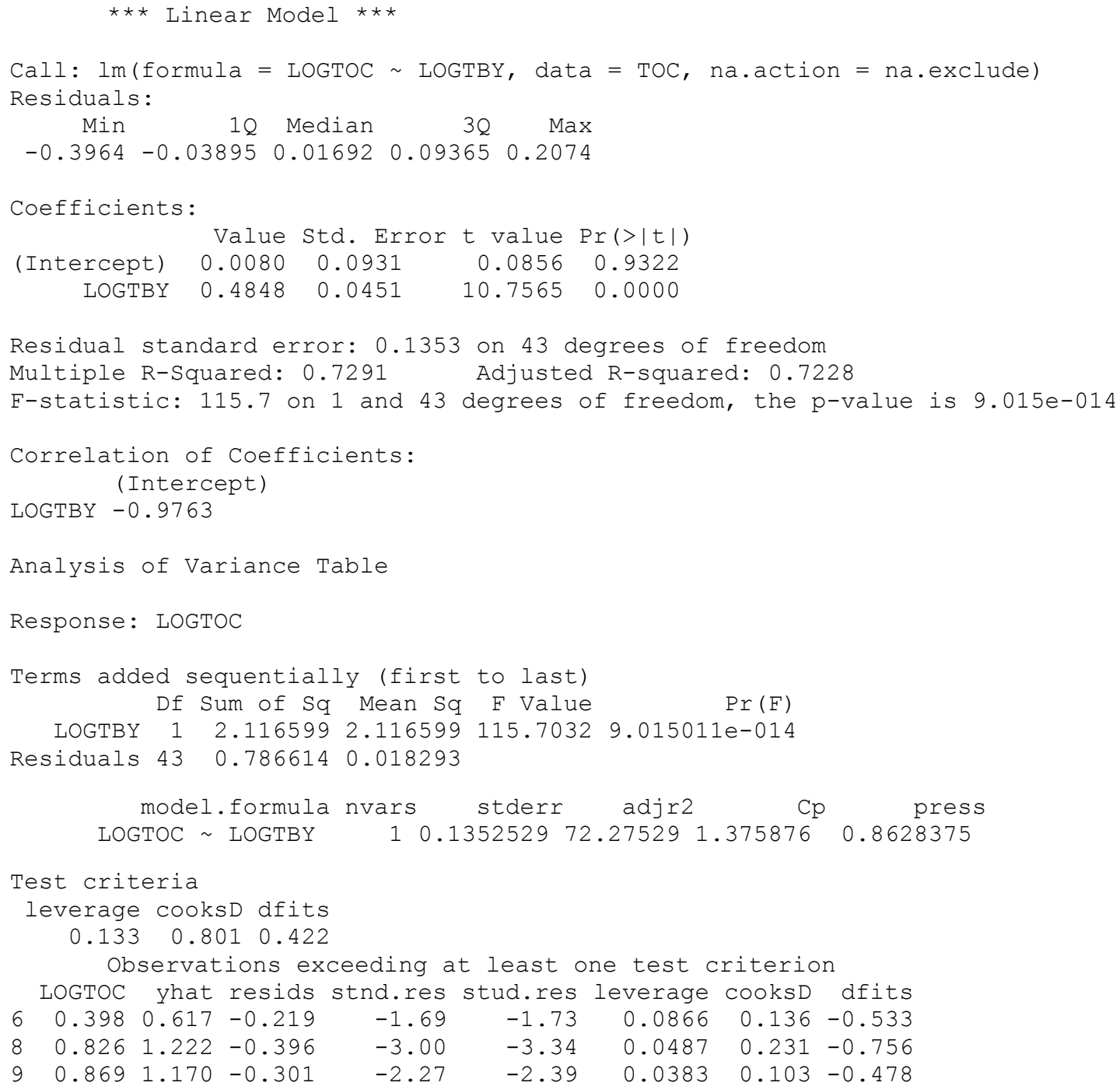

Figure 60. $S+{ }^{\circledR}$ output of regression model development using turbidity (TBY) as the explanatory variable for total organic carbon (TOC) concentrations for the North Fork Ninnescah River upstream from Cheney Reservoir (site 07144780), south-central Kansas, 1999 through 2009. 

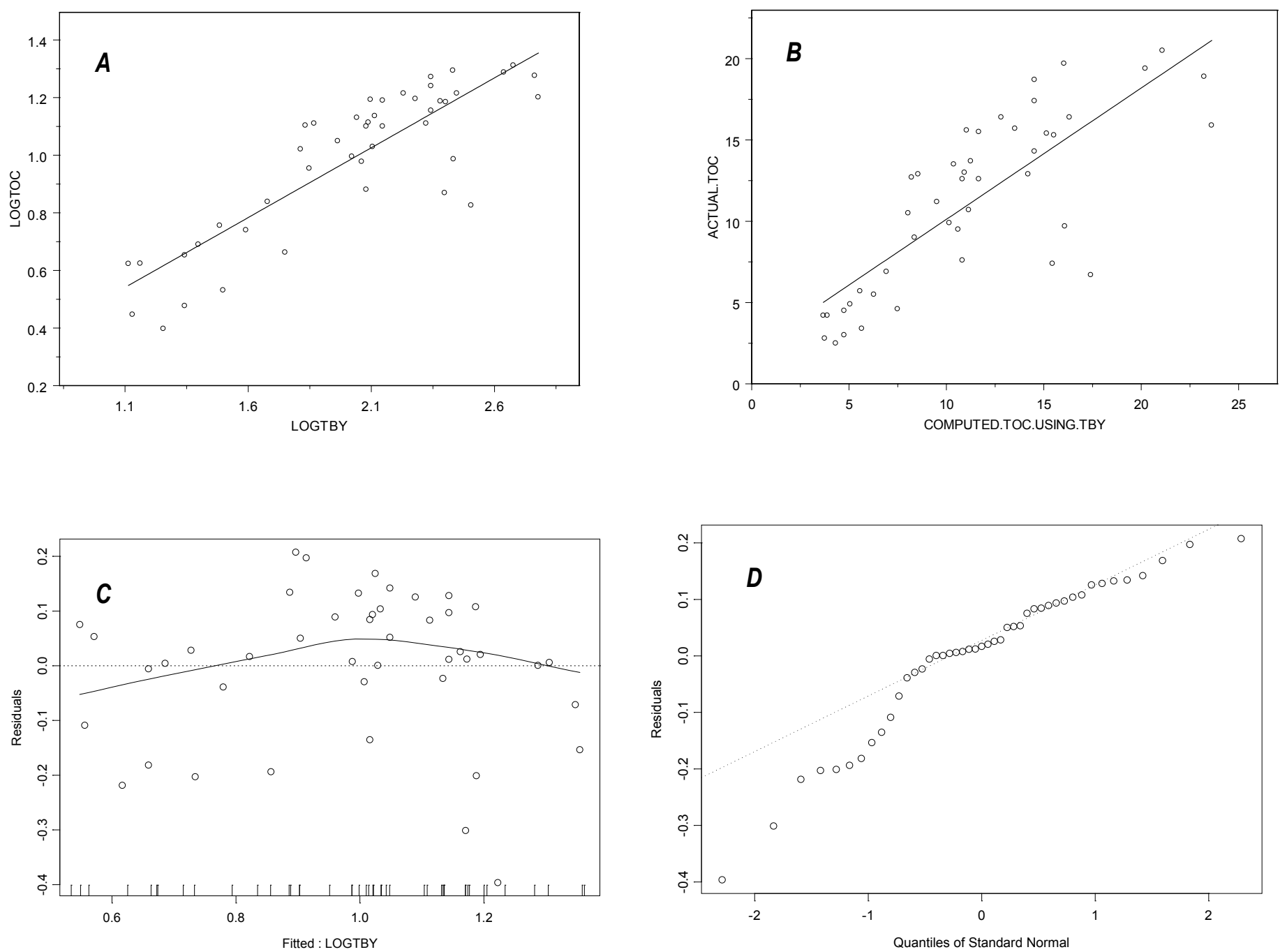

Figure 61. $S+{ }^{\circledR}$ output graphs from simple linear regression analysis showing $A$, log-transformed turbidity (TBY) versus log-transformed total organic carbon (TOC) concentrations; $B$, computed versus actual TOC concentrations; $C$, computed log-transformed TOC concentrations versus regression residuals; and $D$, standard normal quantiles versus regression residuals for the North Fork Ninnescah River upstream from Cheney Reservoir (site 07144780), south-central Kansas, 1999 through 2009. 


\section{Summary}

Cheney Reservoir in south-central Kansas is one of the primary sources of water for the city of Wichita. The North Fork Ninnescah River is the largest contributing tributary to Cheney Reservoir. The U.S. Geological Survey has operated a continuous real-time water-quality monitoring station since 1998 on the North Fork Ninnescah River. Continuously measured water-quality physical properties include streamflow, specific conductance, $\mathrm{pH}$, water temperature, dissolved oxygen, and turbidity. Discrete water-quality samples were collected during 1999 through 2009 and analyzed for sediment, nutrients, bacteria, and other water-quality constituents.

Regression models were developed to establish relations between discretely sampled constituent concentrations and continuously measured physical properties to estimate concentrations of those constituents of interest that are not easily measured in real time because of limitations in sensor technology and fiscal constraints. The water-quality information in this report is important to the city of Wichita because it allows the concentrations of many potential pollutants of interest, including nutrients and sediment, to be estimated in real time and characterized over conditions and time scales that would not be possible otherwise. Regression models based on data collected during 1997 through 2003 were published in 2006. This report updates those models using discrete and continuous data collected during January 1999 through December 2009. The 2006 models for dissolved solids, sodium, chloride, sulfate, calcium, magnesium, potassium, alkalinity, bicarbonate, total suspended solids, suspended-sediment concentration, total Kjeldahl nitrogen, total phosphorus, orthophosphate, and fecal coliform bacteria were updated. New regression models were developed for total nitrogen, nitrate, organic nitrogen, Escherichia coli bacteria, and total organic carbon.

In general, model forms and the amount of variance explained by the models was similar between the original and updated models. The model forms for most updated models remained unchanged. Ions were strongly positively correlated with specific conductance. Sediment was positively correlated with turbidity. Nutrients were generally positively correlated with turbidity. Some nutrient species included either season or specific conductance as explanatory variables. Bacteria was positively correlated to turbidity and negatively correlated with specific conductance.

\section{References Cited}

American Public Health Association, American Water Works Association, and Water Environment Federation, 1995, Standard methods for the examination of water and wastewater (19th ed.): Washington D.C., American Public Health Association, 905 p.
Childress, C.J.O., Foreman, W.T., Conor, B.F., and Maloney, T.J., 1999, New report procedures based on long-term method detection levels and some considerations for interpretations of water-quality data provided by the U.S. Geological Survey National Water Quality Laboratory: U.S. Geological Survey Open-File Report 99-193, 19 p.

Christensen, V.G., Graham, J.L., Milligan, C.R., Pope, L.M., and Ziegler, A.C., 2006, Water quality and relation to tasteand-odor compounds in the North Fork Ninnescah River and Cheney Reservoir, south-central Kansas, 1997-2003: U.S. Geological Survey Scientific Investigations Report 2006-5095, 43 p.

Duan, N., 1983, Smearing estimate: A nonparametric retransformation method: Journal of the American Statistical Association, v. 78, no. 383, p. 605-610.

Fishman, M.J., and Friedman, L.C., 1989, Methods for determination of inorganic substances in water and fluvial sediments: U.S. Geological Survey Techniques of WaterResources Investigations, book 5, chap. A1, 545 p.

Guy, H.P., 1969, Laboratory theory and methods for sediment analysis: U.S. Geological Survey Techniques of WaterResources Investigations, book 5, chap. C1, 58 p.

Hardison, C.H., 1969, Accuracy of streamflow characteristics, in Geological Survey Research, 1969: U.S. Geological Survey Professional Paper 650-D, p. D210-D214.

Helsel, D.R., and Hirsch, R.M., 2002, Statistical methods in water resources-Hydrologic analysis and interpretation: U.S. Geological Survey Techniques of Water-Resources Investigations, book 4, chap. A3, 510 p.

Kansas Applied Remote Sensing Program, 2006, Kansas Land Cover Patterns, accessed August 2012, at http://www.kars. ku.edu/research/2005-kansas-land-cover-patterns-level-iv/.

Peterson, D.L., Whistler, J.L., Lomas, J.M., Dobbs, K.E., Jakubauskas, M.E., and Martinko, E.A., 2005, 2005 Kansas land cover patterns phase I: University of Kansas, Kansas Biological Survey, Report 150, 29 p.

Rasmussen, P. P., Gray, J.R., Glysson, G.D., and Ziegler, A.C., 2009, Guidelines and procedures for computing time-series suspended-sediment concentrations and loads from instream turbidity sensor and streamflow data: U.S. Geological Survey Techniques and Methods, book 3, chap. C4, $53 \mathrm{p}$.

Rasmussen, T.J., Lee, C.J., and Ziegler, A.C., 2008, Estimation of constituent concentrations, loads, and yields in streams of Johnson County, northeast Kansas, using continuous waterquality monitoring and regression models, October 2002 through December 2006: U.S. Geological Survey Scientific Investigations Report 2008-5014, 103 p. 
Rounds, S.A., 2012, Alkalinity and acid neutralizing capacity: U.S. Geological Survey National Manual for the Collection of Water-Quality Data, book 9, chap. 6.6, accessed December 2012, at http://water.usgs.gov/owq/FieldManual/ Chapter6/section6.6/.

TIBCO Software, Inc., 2008, TIBCO Spotfire $\mathrm{S}+{ }^{\circledR} 8.1$ for Windows ${ }^{\circledR}$ User's Guide, $582 \mathrm{p}$.

Turnipseed, D.P., and Sauer, V.B., 2010, Discharge measurements at gaging stations: U.S. Geological Survey Techniques and Methods, book 3, chap. A8, 87 p.

U.S. Geological Survey, 2006, Collection of water samples (ver. 2.0): U.S. Geological Survey Techniques of Water-Resources Investigations, book 9, chap. A4, 166 p., accessed March 2011, at http://pubs.water.usgs.gov/ twri9A4/.

Wagner, R.J., Boulger, R.W., Jr., Oblinger, C.J., and Smith, B.A., 2006, Guidelines and standard procedures for continuous water-quality monitors-Station operation, record computation, and data reporting: U.S. Geological Survey Techniques and Methods, book 1, chap D3, 51 p.
Wilde, F.D., ed., 2008, Field measurements, in National field manual for the collection of water-quality data: U.S. Geological Survey Techniques of Water-Resources Investigations, book 9, chap. A6, p. 3-20.

Ziegler, A.C., and Combs, L.J., 1997, Baseline data-collection and quality control protocols and procedures for the Equus Beds Groundwater Recharge Demonstration Project near Wichita, Kansas, 1995-96: U.S. Geological Survey OpenFile Report 97-235, 57 p.

Ziegler, A.C., Hansen, C.V., and Finn, D.A., 2010, Water quality in the Equus Beds aquifer and the Little Arkansas River before implementation of large-scale artificial recharge, south-central Kansas, 1995-2005: U.S. Geological Survey Scientific Investigations Report 2010-5023, 143 p. 
Publishing support provided by:

Rolla Publishing Service Center

For additional information concerning this publication, contact: Director, USGS Kansas Water Science Center

4821 Quail Crest Place

Lawrence, KS 66049

(785) 842-9909

Or visit the Kansas Water Science Center Web site at: http://ks.water.usgs.gov 



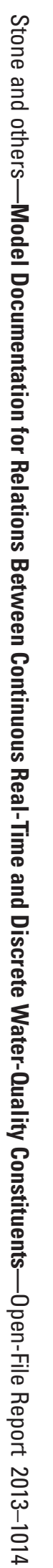

